




\section{A COMMERGIAL GEOGRAPHY OF THE BRITISH EMPIRE}





\section{A COMMERGIAL \\ GEOGRAPHY OF THE BRITISH EMPIRE}

B.

\section{LIONEL W, LYDE \\ M.A., F.R.G.S.}

PROFESSOR OF GEOGRAPHY IN THE UNIVERSITY OF LONDON

"I shall be glad

If all my labours, failing of aught else, Suffice to make some inroad and procure A wider range for thought."

- Paracelsus

ELEVENTH EDITION

- REW rititeN

METHUEN \& CO. LTD. 36 ESSEX STREET W.C.

LONDON 


\begin{tabular}{|c|c|c|c|c|c|}
\hline First Published & . & & & December & 1893 \\
\hline Second Edition & . & & & December & 1897 \\
\hline Third Edition & & & & February & 190 \\
\hline Fourth Edition, & Revised & & & January & 190 \\
\hline Fifth Edition & $\cdot$ & 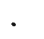 & & October & 1906 \\
\hline Sixth Edition & • & . & & June & 1907 \\
\hline Seventh Edition & . & . & & January & 190 \\
\hline Eighth Edition & - & . & & January & $I 9 I C$ \\
\hline Ninth Edition & - & . & & July & $I 9 I I$ \\
\hline Tenth Edition & & . & & December & $I 9 I$ \\
\hline Eleven & $R e$ & & & $I 922$ & \\
\hline
\end{tabular}




\section{EXTRACT \\ FROM ORIGINAL PREFACE}

"This volume will be found to consist of two partsan Introduction, which treats of general principles, and the Application of such principles, to the larger areas of the British Empire. Apart from the personal interest of the Empire to ourselves, it may also be looked upon as an epitome of the world.

"With this in view, special prominence has been given to special products from different parts of the Globe, e.g. Canadian wheat; and, in the case of that particular product, I have added a detailed account of the conditions under which it is produced-partly because of the intrinsic importance of the subject in a country which cannot provide its inhabitants with home-grown bread, and partly to illustrate a method of treatment which may be applicable elsewhere.

"The study of Geography from the economic point of view is of great moral and social importance, for it is essentially concerned with the production of necessaries. The Multitude have no leisure ; their Standard of Comfort is bare necessity ; and their lives are made utterly sordid and sad by the constant struggle with grinding poverty. Consequently, the physical conditions of their lives make moral and mental growth practically impossible. Of course, wheat could be grown on Ben Nevis, but only at an enormous expense ; and souls are saved amid scenes of the deepest want and suffering, but it is-as it were-reaping upon Ben Nevis.

"Thus, the production of cheap, good food in abundance has a direct and vital bearing on the leisure and, 
therefore, on the possible higher development of the Many; and one great obstacle to it at present is ignorance of the Geographical conditions under which necessaries of life are produced.'

\section{NOTE}

Most of the purely physical sections of the original introduction have been omitted in this edition, partly because of the number of good books published on Physical Geography during the last thirty years, and partly to make room for the new material required by the great increase in the real size of the Empire.

L. W. L.

November, Ig2I 


\section{CONTENTS}

\section{PART I \\ INTRODUCTION}

PAGE

\begin{tabular}{|c|c|c|c|c|}
\hline POPULATION & . & $\cdots$ & . & . \\
\hline SOME ECONOMIC & BEARINGS & OF & CLIMATE & . \\
\hline SOME ECONOMIC & BEARINGS & $\mathrm{OF}$ & RELIEF & . . \\
\hline TRANSPORT & .. & . & . & . . \\
\hline WAR & . & . & . & . \\
\hline
\end{tabular}

PART II

THE BRITISH EMPIRE

$\begin{array}{ccccccc}\text { THE } & \text { BRITISH } & \text { ISLES } & \text { (Surroundings) } & \ldots & \ldots & 38 \\ , " & , " & , & \text { (Surface) } & \ldots & \ldots & 47 \\ ,, & ,, & ,, & \text { (Industries) } & \ldots & \ldots & 50\end{array}$

THE DOMINION OF CANADA (Surrounding ) .. 60

\begin{tabular}{|c|c|c|c|c|c|c|}
\hline " & " & " & $"$ & (Surface) & .. & $\ldots$ \\
\hline " & ", & " & " & (Wheat) & . & .. \\
\hline , & ," & "' & " & (Timber) & . & .. \\
\hline ", & ", & ", & ", & (Pasture) & . & . \\
\hline ', & " & "' & ", & (Fruit) & . & .. \\
\hline ," & ", & "' & " & (Coal and & (ron) & .. \\
\hline ", & ", & , & , & (Precious & Metals) & . \\
\hline ", & , & $"$ & ", & $(F u r s)$ & . & $\ldots$ \\
\hline
\end{tabular}

NEWFOUNDLAND $\quad \ldots \quad$.

BRITISH CENTRAL AMERICA $\ldots$ 


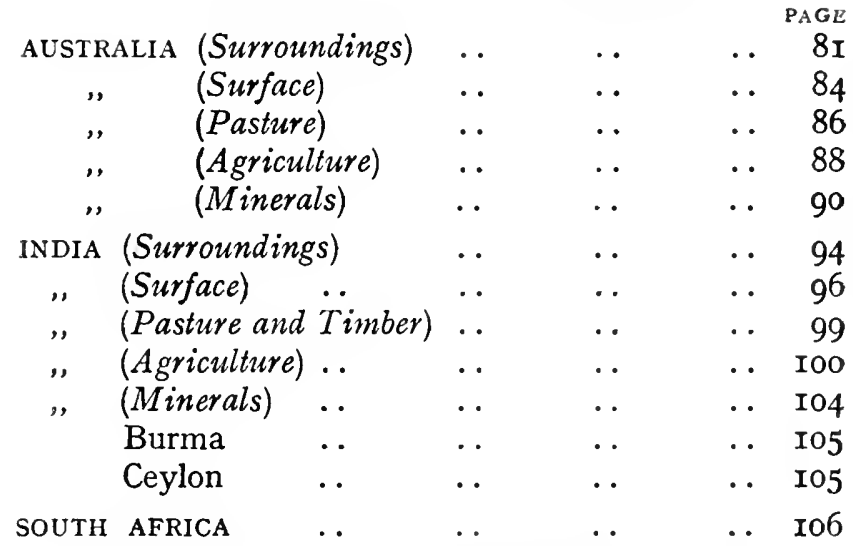

Cape of Good Hope (Surroundings and

Surface) $\quad \ldots$ Io8

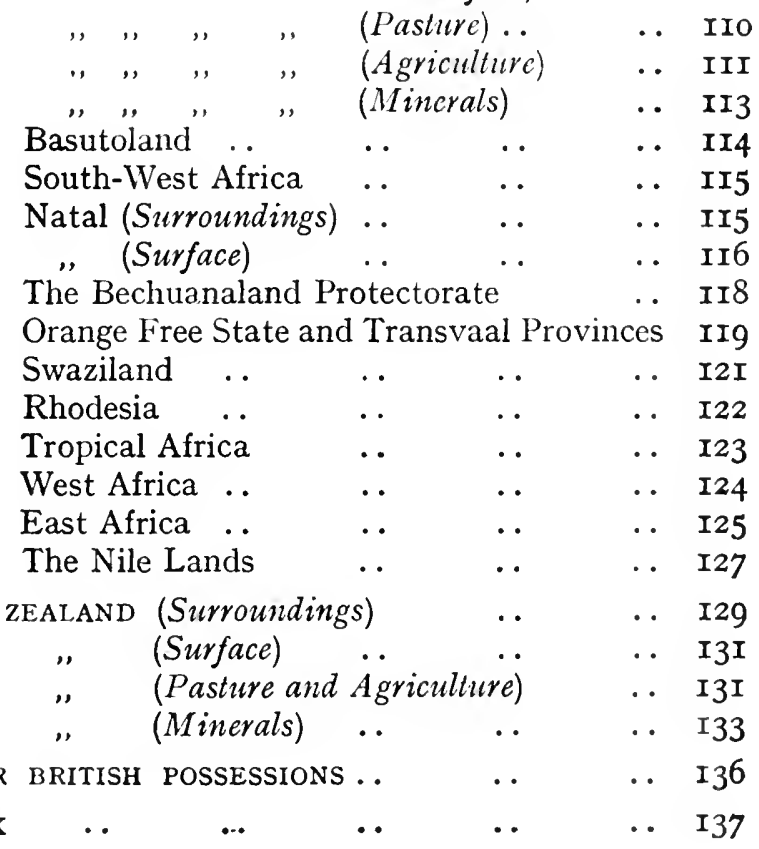




\title{
A COMMERCIAL GEOGRAPHY OF THE BRITISH EMPIRE
}

\author{
PART I \\ INTRODUCTION
}

Commercial Geography may be roughly described as a Study of the earth from the standpoint of the ordinary intelligent merchant. What such a man wants to know is-where he can get the largest amount of the usual commodities, in the best condition, at the shortest distance (of time or space), for the least cost, and with the greatest regularity.

The last consideration is the most important, in many ways; and confidence in the regularity of the supply of any commodity can only come from a thorough knowledge of the conditions under which it is produced. These conditions are investigated by Commercial Geography. It is the office of Commerce to organize all the conveniences and commodities of earth, air, and sea, that affect human life; and Geography supplies the knowledge of the localities in which these conveniences and commodities are to be found.

Human Wants, of course, vary. Everywhere air is the first, and food is the second, necessary of human existence. In countries like Great Britain the third necessary is clothing, and the fourth shelter; but in warmer countries both clothing and shelter become less necessary. This, of course, affects the motive to labour. For instance, the natives of Natal own the huts in which 
they live, and have small pieces of land attached to the huts. On this land they can feed a few cattle and sheep of their own, and grow as much " inealies" as they want for a year; and, as their dress is usually limited to a very small apron, there seems to be no particular reason why they should work. A state of matters such as this, is naturally accentuated where, as e.g. in Mashonaland, the soil is so extraordinarily fertile that cultivation can be confined to a few scratches with a hoe without any fear that the harvest will fail.

\section{POPULATION}

The Distribution of Population over the earth is practically decided by climatic factors. For instance, the islands of the Arctic Archipelago have shores admirably adapted for shipping, soil of great natural fertility, and abundance of mineral wealth ; but the climate makes the islands quite unfit for human habitation.

Also the character of the soil, its condition and the kind of cultivation given to it must be taken into account. All rocks "weather," and their surface is carried off by wind or water to form the soil of the earth. The agents at work in effecting this transformation are the expansion and contraction due to change of temperature, and the means of ingress given to frost and rain by roots of plants ; and, when the soil is once spread over the underlying rocks, it becomes itself a climatic agent. For instance, as the Canadian prairie has been ploughed up, it has been found that the character of the soil and the kind of cultivation distinctly affect the rainfall. Sandy soil is quickly hcated or cooled, while clay soils have the power of retaining heat owing to their moisture. Consequently, the sandy sheep-plains of Australia have intensely hot days and bitterly cold nights, even at a comparatively short distance from the sea, while the most central part of the Canadian clay wheat-lands has 110 sudden and excessive change. 
Moreover, rain follows the plough. Ploughed land retains and eventually evaporates twice as much moisture as unploughed; and, therefore, the cutting down of timber, if accompanied by thorough cultivation of the disforested area, is not likely to affect the rainfall very seriously.

Then, men are by nature gregarious animals; and, even if they were not, the complex conditions of modern life would compel them to congregate in a few large centres. These conditions involve, amongst many other things, minute subdivision of labour and specialization, which apply to countries as well as to individuals. Almost all the great industries may, however, be classed under two general heads-agricultural and manufacturing. The former are connected with large areas of fertile soil, which are found mainly on low plains ; the latter are connected with rich deposits of coal and iron, which are found mainly in the neighbourhood of mountains. In both cases access to navigable water is an immense advantage.

Agriculture-Of the two the agricultural class is much the more important, because the other depends on it directly or indirectly for all its supplies, both of food and of raw material. At the same time, it obviously does not favour the occupation of the ground by dense masses of population; and, therefore, agricultural countries will be less valuable than manufacturing countries as markets.

Manufactures-Various causes effect the distribution of labour in manufacturing countries. In addition to the local position of the minerals and means of transport, association and heredity, or real and imaginary suitability, or climate and special demands for a particular commodity, all exercise an influence on the direction taken by labour. Some labourers serve man's higher wants, intellectual and moral; others perform personal offices for him; others are engaged on the production of real and "acquired" necessities; and so on.

Migrations-In all these spheres it is easier and 
cheaper to take the labourer to the labour than vice versa ; and the migration may be temporary or permanent. The temporary migrations are usually of unskilled labour, e.g. of Irish peasants to England for harvest work ; the permanent migrations are usually from overcrowded to new countries, and take away from the old country the most energetic and daring of her young citizens. These very qualities, however, tend to make the emigrants good customers in their new home; and ties of blood and sentiment and habit tend to give their mother country much of their custom. "Trade follows the Flag." But, of course, the time comes when the young nation begins to manufacture for itself, and so becomes a rival rather than a customer of the mother country.

The Commercial Importance of a nation depends on its industry and intelligence, and these depend largely on its physical conditions. For instance, the rich alluvial soil and the hot enervating climate of the Ganges or Euphrates basin tend to make the inhabitants stationary and slavish; the isolated highlands of Greece or Scotland tend to make the inhabitants vigorous and independent. While the former remain content and insensible to progress, the latter convert their fathers' luxuries into comforts and their fathers' comforts into necessaries.

Wants-Thus there arises a classification of wants into real and acquired. Food, warmth, and rest are real necessaries; but the particular items under each head vary, and the standard of necessity is always being raised. For instance, tea and tobacco, glass and gas, papers and pictures, have become necessaries to the average Briton; with the average Chinaman fish has become a necessary, and he spends his 'spare' time at home in fisling-with every imaginable device and decoy, by day and by night-and eating fish.

Briefly, then, we may say that the densest population will be found on coal-fields near the sea and on the alluvial soil of tropical river-basins. When the soil of 
the latter is very fertile, as along the Ganges, the YangTse-Kiang, and the Hoang-Ho, the tendency of agriculture to make a population stationary will be increased; and the settlement will be very dense. Elsewhere, especially in a Temperate Zone, dense population will mainly be found on coal-fields, as in England, Belgium, Saxony, and Pennsylvania; and such areas will supply a large overflow for emigration. Even on fertile soil, however, in a Temperate Zone, e.g. in Holland and North Italy, the people are compelled to work continuously and energetically; and, consequently, the exigencies of climate and economic conditions counteract the natural tendency of agricultural pursuits to make people lazy and slavish.

SOME ECONOMIC BEARINGS OF CLIMATE

Colonies-of Settlement-The consideration of climatic conditions has caused a classification of Colonies into those of Settlement and those of Exploitation. The tendency of climate, with its accompanying vegetation and conditions of human life, to vary less along Parallels than along Meridians, has caused the continuance of migration westward long after the decay of any superstitious belief in a Land of Eternal Sunshine far in the Golden West; and, if the English colonization of the United States seems to be a colonization southward as well as westward, it must be remembered that the mean temperature of New York is the same as that of London, though the latter is the farther north by $10^{\circ}$.

The larger population required for the development of Colonies of Settlement, based on the similarity of the new to the old conditions of human life, makes such colonization possible only for an over-populated country, e.g. Great Britain; but, even from an over-populated country, it would fail unless the country was rich enough to back up its enterprise.

Colonies-of Trade-Exploitation Colonies, on the contrary, require only the supervising element to be 
provided from the old country; and, therefore, they are suitable for a country like France, which has no surplus population. The conditions of human life in the Tropics, however, by impeding European labour, raise the question of "Where is the labour to come from ?" If from native races, are they to work willingly-for wages, or on compulsion-as slaves?

Holland-The question is immensely complicated by the effect of Geographical conditions on character. Holland is a delta formed by the refuse of the Alps, and prematurely peopled; it is low, flat, damp, and dull. Its physical conditions have demanded thrift, foresight, and endurance from its inhabitants; and these qualities, aided by the experience of a life-long struggle with the sea, taught the Dutch how to fight and conquer the Spanish " Mistress of the Sea."

Egypt is also "the Gift of the River"; and its inhabitants, while enjoying natural boundaries of desert and sea, had no obstacles, in the shape of mountains or forests, to internal communication. The scenery is like that of Holland, flat and monotonous; and there was no timber for shipbuilding, the soil was very rich, and the climate was very hot. Here there was no struggle for existence; but the need for labour, owing to the density of the population and the dryness of the climate, saved its inhabitants from most of the evil effects of such physical conditions. Only they remained stationary and relatively slavish.

Brazil, again, is largely of alluvial formation; but the abundance of moisture produced a dense, dark, damp vegetation, under the shadow of which the natives were overwhelmed amongst bush and creeper. Stunted in physical, mental, and moral growth, they yet had such enormous natural supplies of food that there never was any need for labour any more than there was opportunity for inter-tribal union. Centuries of life under such conditions made the natives unable either to labour or to combine. 
Labour Question-Very different causes have produced very similar results in the natives of Australia and South Africa ; and, therefore, there is a " Labour Question" on the Sugar Plantations of Queensland and Natal. In Queensland, indeed, the question came to a head in I89o, when an Act of Parliament was passed prohibiting the importation of Kanakas from the Pacific Islands, because the trade had become so like a regular slave trade; and the result of the Act, as amended in Igor, has been practically to put an end to the cultivation of sugar by large capitalists. White labour on smaller holdings has been proved, however, so much more efficient than coloured, that it is actually cheaper, and the output per acre has materially increased; but it remains to be seen whether the country can be fully developed under the present conditions of labour even with a Government subsidy.

In Natal coolies are imported to do the work, under contract for a certain number of years; and, at the expiration of their contract, they frequently settle down in the colony as small shopkeepers. The real difficulty, therefore, in Natal is in connexion with animal, not with human, labour ; for the climate of the coast is very fatal to horses and even to oxen.

In South Australia the question takes a very different form. There the climate encourages disease and vermin in the wheat-fields, and yet ripens the crop very rapidly. Consequently, not only is the yield per acre generally small, but also hand labour is both too slow and too expensive for reaping.

Water power-The economic effect of heavy rainfall, e.g. on the western shores of New Zealand or Tasmania, is very marked. For instance, not only have the amount and the violence of the rainfall on the slopes of Mount Bischoff so entirely washed away extraneous matter as to enable the tin to be quarried; but also, as rain falls practically every day, the water power of a cataract I24 
feet high can always be used to drive all the machinery. The same conditions are reproduced in the gold area of the New Zealand Alps; and, as the great force and amount of precipitation depend on the nearness of the mountains to the sea, it follows that there can be very little land at their foot which could be spoilt by the débris necessarily connected with hydraulic mining.

Norway, in this connexion, is worthy of special notice. Its mountain system runs along the very shore of the North Sea, and rises in height towards the south, i.e. the warmer latitudes, where evaporation is heaviest. The evaporation is accentuated by the warmth of the sea, which receives the full benefit of the "Gulf" Drift ; and the height of the mountains is so great that precipitation is complete and sudden. Consequently, there is an enormous number of waterfalls in the country some of them 2,000 feet high, e.g. on the Sogne Fjord, and all of them very close to navigable water and of constant volume. The importance of this to a country which does not possess a single coal-field, is simply incalculable. It is already largely used for motive power in connexion with the various wood industries; and there seems to be no limit to its ultimate development for electrical purposes. The transmission of electricity over long distances is already an accomplished fact. For instance, in the United States effective "power" e.g. for smelting aluminium ore, has been transmitted a distance of 300 miles; and the enormous power of Niagara is being used experimentally, with a view to possibly supplying all factories within a radius of 500 miles, i.e. over an area as large as the whole of the United Kingdom. Its power is equal to at least four times the total steam and water power at present in use in the States. Compared with Norway, however, the States are poor in water power; for she has at least 20,000,000 h.p., i.c. nearly four times as much per caput as even Switzerland has, and her needs for ages can scarcely reach $5,000,000$, 


\section{SOME ECONOMIC BEARINGS OF CIIMATE 9}

Artlficial Light_- "Climate" affects the hours as well as the incidence of labour. The fact that the Earth is spherical obviously causes Degrees of Longitude to differ greatly in length. At the Equator they are nearly equal to a Degree of Latitude-i.e. about 69 miles ; but at Cape Town or Sydney (New South Wales) the distance is about 58 miles; at London, about 44 ; in the north of Labrador, about 34; and off the mouth of the Mackenzie, about 23. All Degrees of Latitude, on the other hand, are practically the same size ; and all places on the same Parallel have the same length of day at the same time. This may help to explain why all the old civilizations sprang up in low Latitudes, where the shortest day is at least ten hours long.

Vegetation-It is important to remember the effect, upon vegetation, of the fact that while the daily, duration of light and heat is extended, the shortness of the night minimizes the time and the opportunity for radiation. For instance, long and continuous sunlight has a marked effect on the quality of grain ; and, therefore, magnificent wheat can be grown at $60^{\circ} \mathrm{N}$. in North-West Canada, and barley can be ripened inside the Arctic Circle in Norway. The advantage of these long days was not apparent until good artificial light was invented to compensate for the consequent long nights during the other half of the year; and, therefore, as pointed out above, early civilization sprang up in latitudes where the shortest day is at least ten hours -e.g. in China, India, Egypt, and Central America.

In highier latitudes, e.g. in Central Canada, the length of day at the time of year when most work has to be done, is of great value to labour; and the presence of snow largely compensates for the shortness of the winter day. As agricultural operations are, however, entirely suspended in the winter owing to the climatic conditions, the short days are quite long enough for such work as can be done, e.g. repairs to building and machinery, threshing, etc, 
In densely populated cities, on the other hand, the height and mass of the buildings, the liability to fogs, and the smoke from ten thousand chimneys, involve a heavy expenditure in the matter of artificial light; and hitherto no real attempt has been made to systematically make use of water-power, even from a short distance, in generating electric light. Something has been done in this direction in Germany and in America, as has been pointed out above; but it seems to have somewhat escaped notice that in winter, when the demand for light would be most constant, the waterpower is almost invariably greatest.

It may, with perfect justice, be said that the climate of the British Isles enables men to work in the open air for more hours a day throughout the whole year than in any other part of the world.

Floods, etc.-Irregular disturbances, such as floods and earthquakes, are, of course, most disastrous to commerce and to commercial confidence. In large rivers, such as the Nile, the Ganges, and the Mississippi, the floods take the form of a more or less regular and reliable rise and fall; but in small rivers, such as the coast rivers in Eastern Australia, the time or amount of flooding cannot be calculated with any hope of accuracy. The presence of lakes is of great value in checking the disastrous rapidity of floods, because the water is spread out over such a large area. For instance, the lakes along the St. John River in New Brunswick effectually prevent the annual floods from being sufficiently sudden and strong to be dangerous to life or property. This is true of almost all the rivers of Canada. The mean annual fluctuation of the level of Lake Superior is not 2 feet; that of the Missouri over the last hundred miles of its course is 15 yards, and even on the lower Mississippi there may be a flood of 90 feet. The most interesting development, however, is the creation of artificial floods, e.g. on the Ohio, the river at normal low water being "held up" until 
enough water has collected to float a fleet of barges down over the shallows.

The normal action of the tides, of course, does a precisely similar work.

Tides-In the open sea the rise and fall is probably less than 2 feet; but, as the water is " narrowed and shallowed " by land formation, the rise and fall increase greatly. For instance, a tide of 30 feet is common in the Bristol Channel; one of 40 feet is common in the Bay of Fundy. These strong tidal currents may be dangerous to shipping directly and indirectly-the latter by heaping up bars at the mouth of rivers; but where, as round the Bay of Fundy, they bring large deposits of fertile mud, they are very valuable to agriculture. With a favourable wind a spring-tide is said to have risen from 70 to go feet in the Bay of Fundy. And, of course, they are enormously useful on our small British rivers, in carrying large vessels up to ports.

The Thames is worthy of special attention. The tidal wave which strikes the coast of France near Brest, is broken into two parts, one of which is diverted up the west coast of Ireland, while the other advances up the English Channel. Eventually a "Channel" and an "Irish" tide arrive in the North Sea, where their meeting has probably caused the Dogger Bank; and the "Channel" tide enters the Thames at the same time as the "Irish" tide, though the latter is really twelve hours behind the former, having had to travel round Scotland. This gives the Thames a double tide; and, as the Thames is very much more free from ice than the Elbe, it thus has two distinct advantages over the German river. This fact becomes more important when it is remembered that, as the only open sea-coast of Germany is round the mouth of the Elbe, German goods must seek markets by the same route and in the same direction as London goods.

Southampton has a double tide in a different sense. It stands on a peninsula between the Test and the 
Itchen, and the same tide comes in twice, first west of the Isle of Wight and then east of it, the Spithead tide coming in two hours later than the Solent tide. While this does not give the exceptional high tides that help-and sometimes even trouble-shipping on the Thames, it effectually prevents there being a low-water minimum.

The effect of climate on earthquakes is less understood, but very important. Certainly, no region is exempt from the change of subterranean pressure caused by the "erosion" of one area and the deposit on another; but the erosion is greatest on mountains, and the deposit is greatest on the floor of the ocean in the neighbourhood of a coast. From this it may be inferred that a low level in the interior of a continental region will be most tree from the actual destructive force of earthquakes, and from the timidity and superstition among its inhabitants which are caused by vast, formidable, and unreliable phenomena.

\section{SOME ECONOMIC BEARINGS OF RELIEF}

Relief-The average elevation of the Earth's land surface is about 2000 feet, which is a quite insignificant amount in comparison with the size of the planet; but some areas reach a height very much greater than that. The average elevation of Asia is nearly 3000 feet; and its highest peak, Mount Everest, is 29,000 feet. Europe has an average of under 1000 feet, though the peak of Elbruz reaches about I8,500. Africa and North America have an average of about 2000 feet; and their highest peaks, Kilimanjaro and Mount M'Kinley, are respectively rather below and rather above 20,000 feet. Aconcagua in South America reaches a height of over 23,000 feet. Australia has no mountains of any really serviceable height!.

Mountains have many uses. They affect climate by keeping off winds or condensing rain ; they form a 
natural boundary to countries; they are the sources of soil for the plains which stretch from their base; though not admitting of much agriculture, they often afford valuable pasture; they do admit of useful irrigation tillage in terraces; and the contortions of their strata expose mineral wealth.

Mountains have usually a dry and a wet side. Vapour-bearing winds are compelled to ascend in trying to cross a mountain range, and the consequent loss of heat causes precipitation on the windward side. This is sometimes sufficient, e.g. in the United States and New Zealand, to cause a dense forest growth, while on the lee side the moisture is only just sufficient for grass. As the wind sinks on this lee side, it is warmed; and the consequent decrease in its relative humidity causes the cloudless sky, dry climate, and great range of temperature, such as are found to the east of the Rocky Mountains.

Rivers-The moisture thus brought to them, they store in pools, lakes, glaciers, and perpetual snow, from which flow perennial rivers; and these rivers carry with them from their mountain cradle immense quantities of soil. It has been calculated that probably five miles' depth of soil has thus been removed from the Appalachian Mountains, and certainly every detail of shape, e.g. the longitudinal valleys, is due to erosion; but this calculation is more or less a guess, and in any case erosion is not uniform even over the same range.

The military value of mountains may be illustrated by the fact that the ranges in which the Cymry found refuge from the Saxon invaders, are still called Cambrian and Cumbrian ; but, of course, in proportion as mountains offer any real protection by height or width or absence of passes, so they offer also serious obstacles to commerce and communication, especially in the absence of railways. An interesting comparison may be made between Russia and Switzerland. With an enormous difference of size, both have special water 
facilities, Russia for communication and Switzerland for mechanical power; and both have been hampered - the one by the enclosing ring of mountains from which it gets its water-power; and the other by the absence of such physical protection-which makes its canal and river system so useful in summer.

Soil-The "weathering" of mountains sometimes supplies a special quality of soil which renders possible the cultivation of a particular plant in an otherwise unlikely place. For instance, the province of New Brunswick is practically unsuited for the production of wheat; but an exception to this is found in the north-west. There the hills which separate New Brunswick from Quebec are composed of slatey clay and limestone; and the weathering of these, fertilized for centuries by the fall of forest leaves, makes an admirable soil for wheat. Somewhat similar conditions have made the Niagara peninsula very famous for its fruit trees.

Another illustration may be taken from The Deccan of India, the north-west segment of which is composed of basaltic rock; and the rich black soil that has been formed by weathering, is able to retain the greater part of the moisture it receives, so making it possible for cotton to be cultivated. Another example still is the loess soil of China; found north of the Yangtse basin, it is the result of the weathering of the Central Asian mountains, and-though rather too porousis very favourable to agriculture.

The Shape of mountains is very largely determined by the material of which they are made, and of which the soil at their base will subsequently be made. For instance, while chalk appears in downs or limestone in tors, granite wcathers into bald, jagged peaks, alternating with decp depressions; and, where the depressions in one range are shut off from the sea by a parallel range, rivers which start on the wet side of the inner range may flow inland through the depressions. This is the case, e.g. with the Peace, 


\section{SOME ECONOMIC BEARINGS OF RELIEF 15}

Liard, and Athabasca rivers, all of which rise west of the Rocky Mountains proper.

In other words, while stratified rocks, such as sandstone and shale, weather regularly, because water can find definite channels along the strata, granite and other unstratified rocks weather irregularly. Volcanic cones, however, are an exception to the general shape of the latter class of rock; and, as their shape does not admit of much glacier formation on their sides, they are of very little use as river feeders during a tropical summer. For instance, the volcanic peaks of the North Island, New Zealand, are of no use in this direction compared with the much lower stratified mountains of the South Island.

Minerals-The exposure of mineral wealth on the sides of hills and mountains and in river valleys, has led to almost all the great mining enterprises in world. Naturally, such exposure comes first on the windward side of high ranges near the sea. Thus, copper was discovered on the west side of the Chilian Andes, tin on the west side of the Arakan Mountains, gold on the west side of the New Zealand Alps, and coal on the west side of the Pennine Range. A similar result often arises from a sudden change of level in the interior of a continent. Thus, coal and iron have been laid bare between Moscow and Tula, copper and nickel between Sudbury and Algoma. The first coal that was mined, or rather quarried, in Scotland was discovered by the Newbattle monks in the Esk valley.

Permeability-All rocks can absorb water, but the power of absorbing it varies very greatly. For instance, compact rocks absorb it very slowly, and then do not allow it to escape ; loose rocks absorb it readily, and pass it on readily. When the rocks are permeable, the water sinks through them until it reaches an impermeable stratum; and, when permeable strata occur between two layers of impermeable strata, there is at once a hope of obtaining water from a natural 
subterranean reservoir. Such water is obtained by Artesian boring; and the future of Central Australia depends on a wide use of this over the limestone formation, though the water is so strongly mineralized that it is of much greater use for watering stock than for irrigating crops, lucerne being almost the only useful crops that can profit from it. The permeability of such formations not only enables water to be stored in this manner, but also prevents the terrible floods which would otherwise follow heavy rain everywhere.

Rivers-Absorbed rainfall also reappears in the shape of rivers, which in turn lose by evaporation a very considerable portion of their volume, to be again precipitated. The amount evaporated, of course, varies with the climate of the particular region: from the Nile it is very great, from the Thames very little. As the amount of evaporation varies, so also does the volume of running water in the river. The Nile does not discharge as much water as the Ohio, which is only one-third of its length; the Mississippi is the longest river in the world, yet both the Amazon and the Congo discharge two or three times as much water every year. Variations in volume are naturally due to the variable supply of precipitation, and, therefore, the larger the basin of the river, i.e. the larger the area from which the supply is collected, the greater is the regularity of the variation.

Rivers water and drain the countries through which they flow; and, where their descent is not too rapid nor their depth too little, they act as great highways of commerce, e.g. the St. Lawrence.

They are the chief agents in the removal of " weathered" rock, either in solution or in suspension, and the amount removed varies greatly with the pace of the current, a doubling of the pace increasing the carrying capacity sixty-four times. Thus rivers like the Rhone, the pace of which often spoils them for navigation, not only supply great motive power, but also deposit an amount of alluvium most valuable to agri- 


\section{SOME ECONOMIC BEARINGS OF RELIEF 17}

culture. For instance, the Rhone discharges into the Gulf of Lions yearly enough solid matter to make a pyramid with a base of $\mathrm{I}$ square mile and a height of quite 200 feet. When the rainfall over the basin of such a river is light, as in the Nile valley, the weathering of the sides of the valley is so slow that the river ploughs itself a deep but narrow bed; and if-in addition to light rainfall-the pace of the river is great, the depth and the narrowness will be excessive, as in the cañons of the North American Cordilleras.

Under such circumstances it is obvious that the value of the river for both irrigation and sedimentation is very greatly impaired. For instance, the Clutha is said to discharge as much water annually as the Nile, and its lower course traverses a coal-field; but there is not a town of any kind at its mouth, or of any size throughout the whole of its lower course! Moreover, the wearing power of a fast river heavily charged with sediment makes its bed very liable to alteration, as is the case with the Clutha and all the other New Zealand rivers.

The Rhine-The ideal river is one like the Rhine or the Nile. The Rhine, "filtered" by passing through Lake Constance, plunges over the Shaffhausen Fall, like the St. Lawrence over Niagara, pure enough to have little corrosive power (though the violence of the Niagara current undermines the soft shale below the fall); the barriers of the Vosges and the Black Forest, only 20 miles apart, have caused the deposit of a large and deep alluvial plain along the Middle Rhine; and the narrow gorge north of Mainz compresses the Lower Rhine into a grinding mill to supply the soil of which Holland is composed.

The Nile flows for 700 miles through Upper or Southern Egypt, the breadth of which is nowhere more than to miles; it is seldom less than $x$ mile broad itself; it passes through no lakes, but does tumble over formidable cataracts ; it, therefore, filled its upper valley with deep alluvium, and, when it was freed from restraint, 
i.e. below the First Cataract, spread out its lower waters to deposit the Delta. The current is always strong enough to carry a vessel down-stream; and during the summer, i.e. from April to October, the Etesian Gales blow up-stream.

In some cases we find a sort of compromise, e.g. on the Saskatchewan. As that river rises in the Rocky Mountains, the melted snows flood it in summer with water heavily charged with alluvium; and the current downstream absolutely prohibits any navigation up-stream. The natural resources of its basin are grain, chiefly wheat. Grain is light in bulk, but cannot bear costly transport ; but it can be, as on the Danube, carried down-stream in flat-bottomed boats quickly and economically. The demand on the wheat-farms is for machinery and manufactured goods, both of which can bear the much more costly transport up-country by rail.

Lakes-The expansion of rivers over lake surfaces not only causes partial or complete sedimentation, but also greatly increases evaporation off the given volume of water; and, if the expansion is extended until the evaporation exceeds the inflow, the water of the lake will gradually become salt, as in the countless Salt Lakes of Australia.

\section{TRANSPORT}

Division of labour, facility of dispatch, and mutual convenience generally cause the concentration of individuals in towns, mainly commercial or manufacturing. In a country like Great Britain, which cannot supply most of its demands from its own home resources, almost all the large commercial towns are ports ; and, of course, the whole existence of a port depends upon its waterway. London, on a good waterway and facing Europe, is by far the most important commercial centre in Great Britain, although coal and iron lie much farther from it than from Glasgow, Barrow, Newcastle, or Liverpool. 
Roads-These commercial centres draw their supplies for export from manufacturing and mining towns of less individual importance; and in all civilized countries properly bridged roads on a reasonable gradient connect all the towns. In old countries these roads are now, thanks to motor traction, regaining the vast importance they had in old the coaching days. In new countries, like Australia, Stock Roads are of great use. They are strips of land about a mile wide, fenced with wire on both sides and provided with water; and in areas of typical grassland they can easily be used by motors.

Motive power-In countries which are not yet under the influence of White people, motive power on all roads is procured almost entirely from animals. In places where insects or climate make it impossible for beasts to live, e.g. in the tsetse region of Africa, human porters are employed; where endurance and sure-footedness are required in a climate that is at least fairly warm and dry, e.g. Southern Europe, donkeys and mules are the cheapest and the most useful; in desert and semi-desert regions, e.g. Central Australia, the camel is indispensable; only yak and sheep can carry loads up and down the rocky paths of the Himalayas; the llama does a similar work in the mining districts of the Andes; and the elephant alone can cope with marshy Tropical vegetation.

Animals can pull more than they can carry; and, where the climate is either very dry or very cold, vehicles can be used even in the absence of roads. Thus dogs and deer draw sledges over the barren snow-fields o Greenland or the mossy Tundras of Russia ; and bullockwagons cross the hard plains of South Africa and America. In Great Britain over the excellent macadamized roads almost all traction has hitherto been done by horses. An average load is-in a two-wheeled cart, I ton,-in a four-wheeled cart, 2 tons, i.e. about twentyfive times as much as a horse can carry on its back as a regular load. 
"Metal "-In countries like Holland or India great difficulty has been experienced in procuring metal for the roads, and many of the Dutch roads are paved with brick. In India, too, the huge rivers offer a very formidable obstacle to successful road communication. In alluvial countries, however, the dead level, and-usually - the presence of navigable water, compensate for the absence of stone; and the possibility of dangerous and destructive floods generally implies the existence of navigable water. But among the massive parallel ranges of the Andes, where, of course, there is abundance of stone, Tropical rains are intensely destructive to imperfectly made roads, and yet there is no compensation in the shape of navigable water. The effect of this on trade may be illustrated from the two republics of Colombia and Ecuador a dozen years ago, though in both there has been considerable improvement recently.

Colombia is naturally endowed with a wonderfully rich soil, great mineral wealth, dense forests, and a river, the Magdalena, which is navigable by boats for $45^{\circ}$ miles from the sea to Honda; and the country had enjoyed long tranquility. Yet for several months in every year there could be little or no trade, because the so-called roads were made impassable by rain. Even the capital, Bogota, was quite inaccessible at times, although the distance to Honda from the plateau on which it stands is only 42 miles. The mail, carried on mules, was often over three days in doing that distance ; and goods were often three weeks on the way. This delay, and the rough usage of the goods during the bad weather, caused great loss and annoyance to the local mercliants. Now, by rail and steamer via Guardat, Bogota can be reached with comparative ease, and there are a dozen lines of railway in the country, though the task of linking them up is one of immense difficulty and expense.

Ecuador was in an even worse position! The natural result was a continual decline in trade, which was accounted for by the Director of Commercial Statistics 


\section{TRANSPOR'T}

at Guayaquil in a dozen different excuses :- $\mathrm{A}$ bad cocoa harvest, the low price of ivory nuts in Europe, political revolutions, the transfer of capital abroad, the exclusion of Bolivian and Colombian coin from circulation in the country, the denunciation of the commercial treaty with Colombia, the imperfections of the customs tariff, the absorption of local capital by the large and constant loans to the Government, the recent financial crisis in Europe!

There were, however, a few neglected items. The means of internal communication were in such an extraordinary condition that people in different parts of the country were absolutely strangers to one another-so much so that the notes issued by the banks in the capital, Quito, were not current in the chief port, Guayaquil. The so-called roads were generally mule-tracks, which were practically closed throughout the rainy season, i.e. for half the year; and, where there was no readymade mule-track, recourse was had to the bed of a torrent which had ploughed a fairly distinct channel through the loose volcanic soil. Even over the main track from Quito to Guayaquil merchandise could not pass at all during the winter; and a mounted postman was actually drowned in the mud in attempting to carry letters between the two cities. Even in the open season goods sometimes took six months to travel over the 200 miles of land between Bodegas and Quito.

It is worthy of notice that the national character was responsible for this absurd condition of affairs ; splendid causeways were originally built and maintained by the Incas, but their conquerors have squandered on convents and churches twice as much money as would have kept the old works in decent repair. Other instances of incredible folly were not wanting. Agriculture meant scratching the surface of the soil with a wooden plough ; ripe wheat was cut with a knife, while every grain of maize was picked separately out of the ear ; winnowing was done by hand; and the first man who dared to import a cart to facilitate harvesting, was promptly 


\section{A COMMERCIAL GEOGRAPHY}

fined! Here again, there has been great improvement; for a railway between Quito and Guayaquil was completed in Igo8, and the main road between the two is kept in very fair condition.

Railways are still the surest medium of communication, even if less rapid than aeroplanes; and they are usually much cheaper, all things considered, than inland water transport. Their cost depends largely on the price of land and on the difficulty of making the permanent way and of procuring materials; the gradient decides the gauge, and the gauge decides the amount of materials needed. A steep gradient requires a narrow gange, and that prohibits speed; but hill products are usually minerals, which have great weight in small bulk, and for which speed is not needed. Plain products are usually vegetable, and have small weight in great bulk; and the population of plains demands speed, which is impossible without a fairly broad gauge.

In thinly peopled, newly settled countries railways are very valuable in developing natural resources; and, therefore, special efforts are necessary, e.g. in the British Colonies, to provide railway accommodation. Reference will be made below to the great Canadian system ; in New Zealand an equally good system is in use, though it has no Imperial value, and its effect has been very marked. The Maoris and the contour of the country tended to produce isolation of the various settlements; but the railway commerce has broken down all such isolation, and has proved a real federal bond. Indeed, the railway accommodation, e.g. at docks, is so far ahead of actual wants that it involves the Colony at present in some temporary loss and debt.

Gauge-The only drawback to the New Zealand railway system is that its different lengths are not all in comncxion with one another; and the same is true of the Australian system. While, however, in New Zealand there is in places a double gauge to accommodate different kinds of traffic and connect different kinds of country, 
in Australia each colony except South Australia had originally only one gauge, and each of the great colonies had a different one. This, of course, absolutely prohibited any through traffic; and the Commonwealth is now bringing all lines to a uniform gauge ( $4 \mathrm{ft} .8 \frac{1}{2} \mathrm{in}$.), as was done in the United States in I886.

The gauge in New South Wales was $4 \mathrm{ft}$. 81 in., in Victoria $5 \mathrm{ft} .3 \mathrm{in}$., in Queensland, Western Australia, and Tasmania, $3 \mathrm{ft} .6$ in.; in South Australia there were two $-3 \mathrm{ft} .6$ in., and $5 \mathrm{ft} .3 \mathrm{in}$.

The effect of this on even comparatively unimportant industries was illustrated by the slow growth of the Victorian fish trade.

The commercial products of the sea are of immense importance, partly because the sea is infinitely more productive than the land, and partly because marine industries have a very significant relation to commerce and defence as well as to food and agricultural science. The average crop of wheat per acre throughout the world is roughly half a ton, and there is practically no place in which more than one crop can be gathered in each year; but three tons of fish can be caught by one boat in one night over quite a few acres of sea, and there is three times as much sea as land in the world. ( $\mathrm{llb}$. of bread may $=2 \frac{1}{2} \mathrm{lbs}$. of fish.)

Now the general idea that the Australasian Waters are very badly supplied with fish is quite erroneous. Apart altogether from the shark fishery of New Zealand, which is in a most prosperous condition, there are various flourishing fisheries connected with, e.g. the Victorian ports of Frankston and Hastings; but reasonable precautions must be taken with regard to season and situation, the colder waters producing the finer fish. This implies that the Victorian fisheries might be very largely developed; but, of course, such development would be practically impossible without a uniform Inter-Colonial gauge to prevent the delay and expense connected with transference of goods. 
Railways are naturally more important in continental than in maritime countries; but everywhere their influence has done more than anything else to promote the wonderful commercial development of the last halfcentury. Towns like Crewe or Swindon, and cities like Chicago or Winnipeg, owe their very existence to railway influence; and many cities in Europe owe their importance to the same cause. For instance, it is well worth while noticing where the lines from Calais to Marseilles, from Rotterdam or Hamburg to Genoa, from Stettin to Trieste, from Libau to Sebastopol, or from Riga to Tsaritsin, cross the great lines from Paris to Bucharest, Constantinople, and Salonica, from Paris to Moscow, from Hamburg to Odessa, from Lisbon to Brindisi, or from Cadiz to Petrograd. Attention will thus be drawn to the enormous importance of, e.g. Switzerland as a transit centre.

Special Railways are in use for special purposes. For instance, tooth-rail or rope railways climb the Rigi and other Swiss mountains; there are overhead railways in Liverpool and New York, and underground railways in London and Glasgow.

A Railway Company in Great Britain is simply a trader on a very large scale. What it has to sell, is transport service; and its object is to conduct its service so as to attract the largest possible amount of business. Consequently, if any particular company in the country is flourishing in spite of competition by rail, road, sea, and river, there is only one legitimate inference, namely; that it is giving the public a fair article at a reasonable price. At the same time, it is obvious that the company can afford to give the best terms to its largest and most regular customers ; and, therefore, the so-called " undue preference for foreigners " is simply an ultra-patriotic interpretation of a perfectly just and logical economic law.

It would secm to be obvious also that, as all men are consumers, competition-which must be lessened by the grouping of railways-must be advantageous to the 
public, however disadvantageous it may be to individual traders; and it is certainly a fact, whether obvious or not, that fish from Wick cannot compete in London with fish from Great Grimsby, or beef from Wyoming with beef from Westmoreland, unless a lower rate per mile is charged over the longer distance. In a word, it is entirely to the advantage of the consumer that railways should neutralize natural geographical advantages; and this truth implies also that the charge made for the carriage of any particular commodity should be proportioned to the relative value of the service to the public rather than to the relative cost of the service to the company. That is to say, silk must pay more than bread, however much the Macclesfield manufacturers may complain.

British Conditions-Further, three things may be noticed in this connexion. One is that the cost of the carriage of goods in this country is a comparatively unimportant item in their total cost, owing to the shortness of the distances; and this cost would be still smaller if the local traffic were in wholesale, as in the United States, instead of in retail quantities. This, however, is quite impossible for "way-side" stations, unless we introduce the despotic measures in rogue in the States; and, on the other hand, between all the large commercial centres in the country there is such fierce competition for carriage that rates cannot be high. The second point is that English railway rates include the collection and the delivery of the goods, which are practically never included in Continental rates; and they are usually paid for goods carried at the risk of the company and at a very much quicker pace than is ever thought of on the Continent. Thirdly, although inland water carriage is naturally cheaper than land carriage, even the canals not owned by railways are comparatively unused; at all events, it cannot compete with the railway system when the rate is compared with the efficiency of the service. Otherwise, the canals would be more used than they are at present. 
It is, therefore, obvious that, however much " undue preference for foreigners" there may be, the rates charged to natives (I) cannot, with much semblance of justice, be called extortionate, and (2) are distinctly to the advantage of the consumer. On the other hand, it is distinctly to the disadvantage of the consumer that railway companies should be compelled to pay such extortionate prices for their land in the first instance, and then to pay such heavy taxes on that land. For these expenses subsequently re-appear as interest on capital - the English companies in I9I3 paid an average of under $4 \%$-to be defrayed by " cost of carriage." The latter has also to defray movement expenses, station expenses, and maintenance of way; and on each of these points the British public is more much exacting than the American or the Continental. It refuses to wait itself, or to arrange its business so that it can travel at times convenient to the company, or to wait for its goods : it is impossible to imagine-except in war time, or while the railways are under Government controlan Aberdeen merchant waiting, as he would be compelled to wait in France or Germany, a week for goods from London. It refuses to be content with trestle bridges, wooden platforms, and rails laid directly on to the bare rock. It demands signalmen at specified distances and separate rails for special traffic.

Under such circumstances, it would not be surprising if English rates were high, and that, too, without being in the least extortionate; and some of them are unjustifiably high, especially those for local traffic in small quantities. On the other hand, some of them are actually very low, especially those for food in wholesale quantities; but in many of these cases middlemen rob both the producer and the consumer of all the advantage which ought to accrue to both from the low rate. For instance, it has been publicly asserted, on behalf of the Montrose fishermen, that, out of the total cost of their cod to the consumer in London, not $7 \%$ goes into the 
pockets of the men who own and man the boats; and it is acknowledged that the railway rate to London averages about $7 \%$. Where the other $86 \%$ goes is " not found." In such cases it is morally certain that any decrease of the rate would only go to increase the enormous profits already made by the middlemen.

Water Carriage, by river or sea, is cheaper than land carriage, because the water itself bears the weight, and only motive power is needed. For instance, the same horse that could only draw one ton in a two-wheeled cart can draw forty tons in a barge! Consequently, goods that are very heavy or of little value, must be carried by water; and this fact will for a long time impede the development of, e.g. copper mining in Australia, or iron mining in South Africa.

But the arguments borrowed from foreign canals by those who wish our home canals to be nationalized and improved, usually ignore all the geographical side of the question. The relief of England involves an average of one lock for every one and a quarter miles of canal, a terrible tax on speed. The climate limits the size of the locks-unless expensive pumping is used-for where the population needs canals most, because it is densest, the demand on the limited rainfall for drinking purposes is heaviest, e.g. in the Black Country. In these densely peopled and built-over areas the cost of widening canals would be so enormous that an improved "Grand Junction Canal " could not afford to tap places like Birmingham and Wolverhampton, at a height of over 400 feet, and undermined in a way which already causes constant subsidence and terrible leakage.

Inland canals are "out of date" for modern conditions of English business, for traders no longer store huge quantities of goods, but buy small lots often ; and canals are too immobile to reach new works casily, and too irregular in speed and punctuality. This fundamental position is obscured by assertions that canals are "strangled" by the Railway Companies. But $70 \%$ 
of our canals are not under the Railways at all, including such important through routes as the Grand Junction, Leeds and Liverpooi, Aire and Calder, and all the canals between London and the Derby and Notts coal-field.

Cost-The wonderful cheapening of sea carriage has been due partly to more scientific knowledge of the regular currents of wind and water, and partly to inventions for saving fuel or diminishing resistance. For instance, for years now Atlantic liners have been all built " sharp," and triple-expansion engines have been able to drive ten tons of cargo across the Atlantic with about the same expenditure of coal which used to drive only half a ton! Morcover, this saving of fuel has been accompanied by a positive increase of speed; and the combination of increased speed with decreased cost enables many commodities to be now conveyed great distances by sea. More recently many vessels have been using oil as the sole, or as auxiliary, fuel; and the oil has greater heating power, weight for weight it occupies less space, and it saves dozens of stokers.

Currents - The use of currents of wind and water is, of course, much more important to sailing ships than to steamers. For instance, a clipper leaving a British port for Australasia at first hugs the European coast, in order to get the full advantage of the N.E. Trades; but south of the Equator she hugs the American coast, in order to avoid the S.E. Trades, and holds on southward till she reaches the latitude of " The Roaring Forties." Then before "the Brave West Winds" she holds due east past the Cape of Good Hope. On the return journey, all this is reversed. Holding still eastward, she makes Cape Horn, and keeps on her course till she is near enough to the African coast to get the full advantage of the S.E. Trades; but north of the Equator she hugs the American coast, in order to avoid the N.E. Trades and to take full advantage of the S.W. Anti-trades.

Steam-It was partly the desire to be independent of all currents that caused wooden clippers to be uni- 


\section{TRANSPORT}

versally discarded-till quite recently-in favour of iron and steel steamers. This tendency became so strong that some places once famous for their wooden clippers entirely lost their shipbuilding trade. This has been the case with all the eastern provinces of Canada except Nova Scotia, which is the only one possessing large deposits of good coal and iron in close proximity to one another. Even steamers, however, are affected by currents and winds, especially by regular winds such as the N.E. Trades in the North Atlantic, or the "Brave West Winds" of the "Roaring Forties" in the South Atlantic and South Pacific. It is due to the latter, for instance, that the outward route to New Zealand, even for steamers, is round the Cape of Good Hope, while the homeward route is round Cape Horn. In this particular case the outward voyage is further facilitated by the regularity of the N.W. Anti-Trades in the South Atlantic, which is itself due probably to the comparatively small area of land in the southern or "water" hemisphere; and certainly the regularity of the passages made by, e.g. the steamers of the New Zealand Shipping Company, is very remarkable. Again, steamers are much more adapted than clippers to artificial waterways, and so tend to save " breaking of bulk," and consequent trans-shipment expenses. Railways have the same advantage over canals.

Goods-The change from clippers to steamers is, however, partly due to the character of the commodities carried. For instance, tea is very sensitive to a long sea-voyage; and fruit, butter, and live cattle-the trades in which are all of recent growth-must have quick transit. Of course, the question of competition has also to be considered; and it is further complicated by the fact that different parts of the world have their harvests at different times. For instance, the summer is earlier in Cape Colony than in any other British possession south of the Equator; and, if Cape Fruit can arrive in England in January, it practically has the market to 
itself. Now, the soil and the climate of the Cape are wonderfully well suited to the vine; the direct steamers, e.g. those of the Castle line, make no stoppage except for a few hours at Madeira; Cape Town is almost in a straight line with London; Lisbon, the port of cork dust in which to pack the fruit, is en route; and almost all steamers trading southward past Lisbon call at Cape Town for coal before entering the latitude of the " Roaring Forties." The Cape is, therefore, the natural source to which British merchants should look for a regular supply of fresh grapes during mid-winter in Great Britain.

Shortening of Actual Distance is, of course, the same thing as shortening the time; and the desire to combine the two with the cheapest possible mode of carrying, i.e. by water, has led to an immense development in the construction of canals and the canalization of rivers. Moreover, the further desire to economize fuel and to make it go as far as possible has led to a great increase in the size of ocean vessels. To accommodate these monsters very extensive harbour works have had to be constructed; and where this has been neglected, a number of old river-ports have been supplanted by new sea-ports lower down on the same river. For instance, Pauillac has largely supplanted Bordeaux, as St. Nazaire has Nantes. So Cuxhaven, not Hamburg, is the terminus of the Hamburg-American line.

This principle holds good with regard to ports which are near one another, but not on the same river. For instance, Surat was once much more important than Bombay as a harbour, just because it stands fourteen miles up a river, and the light vessels of those days could thus load or unload farther from the sea. Now that the enormous increase in the amount of trade has necessitated an increase in the size of vessels, and that the unique advantages of the Bombay Harbour to Indian shipping have necessitated the building of railways across the Western Ghats to provide Bombay with inland com- 
munication, the river port of Surat has sunk into absolute insignificance beside the ocean port of Bombay.

Canals-The development of Bombay is very largely due to the opening of the Suez Canal, which revolutionized the Eastern carrying trade. Indeed, the success of the Canal may perhaps be gauged best from the number of its imitators, the most important being that across the Panama isthmus. From all ports on the west coast of America north of Panama, it saves 8,400 miles to New York, and 9,400 miles to New Orleans; but the saving from ports south of Panama varies greatly -from I,500 miles from Valparaiso to 5,000 miles from Guayaquil. The saving to Liverpool from ports in Eastern Asia will also be great, e.g. 3,000 miles from Shanghai and 4,600 from Manila; but, all things considered, the route is not of great value to the British. Even New Zealand is not made much nearer to England by it, and India and Australia are still nearer by the Suez. The harbour that profits most by it is Kobe.

The Corinth Canal may serve as a model of the rest, although, as a matter of fact, it is a failure commercially, because its deficient width and strong current limit its traffic to small vessels. It does not cross the isthmus in the narrowest part, or even along the lowest level, the question of keeping surface drainage out of the canal being of the greatest importance; and it is curious that the course of the present work is almost exactly the same as that of Nero's similar undertaking. Theoretically it ought to give a smoother and much shorter passage from Italy to the Black Sea than that round the Morea; and practically shipping must benefit by the improved lighting throughout the Gulf of Corinth which the traffic through the canal demanded. Incidentally, some very beautiful and interesting scenery-including Olympia, Delphi, and Parnassus-has been made easier of access.

In every part of the civilized world where water is procurable a similar development of canal construction is going on. In Great Britain, for instance, Manchester 
was made a seaport by the canal from Eastham Ferry ; in Canada a canal is being constructed from Georgian Bay via the Ottawa river to Ottawa; in Germany direct water communication between Kiel Bay and the Elbe was provided by the Baltic and North Sea Canal. In the latter case, the dangers of the Sound route are also avoided, but the main object was strategic-to make the two, North Sea and Baltic, fronts into a single front, with concentration on interior lines. And it is noteworthy that the Great War seems to have begun within six weeks of the official notice to the ex-Kaiser that the canal was ready for "Super-Dreadnoughts."

Where it is simply a question of saving time, but the tidal conditions make a canal impossible, recourse may sometimes be had to a Ship Railway. For instance, the tides in the Bay of Fundy are the highest and fastest in the world; in Northumberland Strait they do not rise more than 7 feet. Consequently, a canal from the one to the other is impossible; but a perfectly straight railway might be built, which would convey ships of 2,000 tons across the eleven and a half miles of the isthmus of Chignecto without any unshipment of cargo.

In these cases the question is purely a Geographical one, as is also the question of conveying products (e.g. those of Natal or Mashonaland) to the necessary markets ; but the character of the demand for commodities in any given place, and many labour questions, are more purely Economic.

\section{IVAR}

Its Evils-In some cases, of course, there is also a political question in the background, involving the possibility, if not the probability, of war. War is-from a commercial point of vicw-an almost unmixed evil. Not only does it utterly disorganize all commerce while it lasts, but the possibility of it, and the preparation for it, involve nations in countless economic absurdities, e.g. 
difference of railway gauge, the hindrance of fortifications to the natural growth of towns, the loss of male adult labour during the period of compulsory service under a conscription, and the enormous taxation necessary to maintain the various military and naval establishments.

Incidental Effects-War has had, however, curious effects on the development of industry and commerce in a few cases. For instance, the wonderful canal system of Canada and the railway system of India were created originally for military reasons; and, thanks to the one, ocean vessels can now load grain 2,000 miles up-country from the coast of Nova Scotia ; and, thanks to the other, famines in India have become much fewer and very much less fatal than in former times. It is also largely for political reasons that the canal system of Canada has been so wonderfully supplemented by railways, especially by the Canadian Pacific Railway ; and yet the commercial importance of the Canadian railways may be gauged from the fact that, quite contrary to custom, the Government built only a very small portion of the Canadian system. Of course, every encouragement has been given by the Government to railway enterprise in Canada, nearly $£ 30,000$,000 having been spent at different times in the shape of bonuses, and most extensive grants of land having been made in different parts of the country, especially in Central Canada; but the great Canadian Pacific Railway system was entirely a private enterprise.

The Canadian Pacific Railway system is of enormous importance. It provides uninterrupted communication across North America on British territory, and much the shortest route from Great Britain to the east coast of Asia and Australia. Moreover, it has most valuable deposits of coal at both ends and en route; and the terminal coal-fields are close to two of the finest harbours in the world, Esquimalt and Halifax, both of which possess graving docks that are capable of holding the largest vessels in existence. In times of possible war, especially with any 'Mediterranean' Power, the Suez Canal route 
to India would be too dangerous, and the Cape route too long; but the Canadian Pacific Railway would afford a perfectly safe and quick alternative route.

Sugar-Actual war with two European countries had a marked effect on some industries in or closely connected with Great Britain. For instance, the Napoleonic wars rendered the import of timber from the Baltic to Great Britain quite unreliable; and, at the same time, Lord Nelson completely cut off the French sea-borne supplies, e.g. of sugar. In consequence, the French commenced to grow beet-root for sugar-to the utter ruin of the Bristol sugar trade; and British merchants began to import timber from Canada. To this, indeed, Canada owes much of her subsequent prosperity, for the lumberers were the best possible pioneers of the countryclearing the land, making roads, and bridging rivers.

Jute-A similar state of things arose at the time of the Crimean War, when the import of flax and hemp into Great Britain from Russia was, of course, abruptly stopped. To supply the want, British merchants began to turn their attention to India, and the jute industry was commenced which has since then attained such wide dimensions. India reaped advantage also from the American Civil War. That struggle stopped the export of cotton from the Southern States; and this, in turn, caused the most terrible distress among the Lancashire spinners and weavers and the Lanarkshire printers and dyers. To remedy the distress, and to ensure, as far as possible, that it should never occur again, a large area of land in the basin of the Tapti was laid down in cotton; and it was thus discovered that the remarkable power of the Indian "black soil" to retain moisture, the amount of lime in the soil, and the entire absence of frost, guaranteed-with careful cultivation and harvesting - a plentiful supply of cheap cotton from Bombay. It should be noticed, however, that Indian cotton is short in staple, and therefore of less use than American cotton for spinning finc yarn. It is also, for the same 
reason, not well suited to the Lancashire mills. At the same time, work in cotton factories in the latitude of Bombay can be carried on for at least eighty hours a week the whole year through without any artificial light. This is one reason why the competition of the Bombay mills has ruined the trade of South Lancashire with India in coarse yarns.

Of course, the shortening of actual distances by mechanical means, such as the Suez Canal and the Queensferry Railway Bridge, is of the highest importance; and the shortening of time over such distances, e.g. by the introduction of artificial lights along the Suez Canal to enable vessels to pass through by night, still further reduces the cost.

Fishing-The importance of marine industries in relation to commerce and to defence, as well as to food and to agriculture, is too much taken for granted in Great Britain. The fisheries of the Cornish peninsula and of Brittany have been of equal importance to the commerce and defence of their respective countries; but, while no recognition of this is shown by the British Government, the French spend hundreds of thousands of francs every year on bounties to fishermen. The Canadian Government pursue the same patriotic, if uneconomic, policy; and, by their minute and instant attention to the needs of their fishermen, they show that they look upon them as a possible and invaluable Marine in times of national danger, as they were in I9I4.

British Commerce is, however, of such enormous extent that it does receive special attention, partly in the maintenance of a very powerful navy and partly in the occupation of posts of vantage along the great trade routes. The North Atlantic route, with its abundant supplies of steam-coal in Lancashire and Nova Scotia, does not need such posts; and, if it did, there are none in the North Atlantic. The Cape Horn route is almost equally destitute, the only coaling stations for Chilibound vessels after learing the Azores being Rio and 
Monte Video; but the weather by this route is very adverse, and the trans-continental railways of Canada and the opening of the Panama Canal have practically stopped all traffic to New Zealand via the Horn. In any case, the only post of vantage held by Great Britain on this route is the group of the Falkland Islands.

The three other great routes- the Suez and Mediterranean, the Cape, and the Panama or West Indian-need, and have, many such posts. The Suez route is the most important of the three, and is via Gibraltar, Malta, Perim, Aden, and Point de Galle; the Cape route is via (the Azores, Madeira, the Canaries, the Cape Verde islands $\left.{ }^{1}\right)$ Ascension and St. Helena; the West Indian route is via the Bermudas and Bahamas, or via St. Thomas and Jamaica. In all these cases, however, the coal has to be sea-borne; and, therefore, its price is very mucl higher than at the pit mouth, e.g. along the Canadian Pacific Railway and at its two termini.

Export of Coal-The importance of sea carriage to a country like Great Britain is incalculable, but it lies in two facts: the internal trade of a small country that is rich in coal and iron, must merge into an external trade ; and for this sea-ports are the distributing centres. Germany, a large continental power in much the same latitude, and therefore working under much the same conditions, as Great Britain, has little sea-coast. All that little is in the nortli, and the only open sea-ports are in the north-west. Consequently, German goods must seek markets in the same direction as British goods do ; the Elbe becomes naturally the rival of the Thames. The latter, lowever, is much freer from ice than the former, and has unique tidal conditions. On the other liand, our whole sea trade is based on the export of coal; prices will never fall in this country unless and until we are again exporting at least 50,000,000-by preference, $70,000,000$ - tons of coal at a price which our foreign customers can afford to pay.

\section{Not British.}




\section{PART II \\ THE BRITISH EMPIRE}

THE British Empire, even without mandate territories, covers more than one-fifth of the land of the Globe, and the tonnage of its Merchant Navy before the war was very nearly equal to that of all the other countries in the world put together. Excluding sailing vessels, the proportion was even larger. The total steamer tonnage of the world was then estimated at $36,000,000$; and of that of the British Empire owned about I7,500,000.

The reason for this is that the Empire is an Oceanic Empire,- that is to say, an empire the different parts of which are "divided" by oceans. Once that was, or might have been, a drawback ; but now, for all commercial purposes, union by water is positively better than union by land. Of course, some of our Colonies are at an immense distance; but shortening time is the same as shortening space, and our "Ocean Greyhounds" are much faster than most of the Railway "Expresses" of the world. And the cheapness and the comfort of travelling under the Red Ensign are unrivalled. Not only, then, do modern facilities for communication minimize the disadvantage of distance; but this is more than counterbalanced by the advantages which come from the great differences of climates, seasons, soils, etc., enjoyed by the various parts of the Empire.

The war made a great change in the relative size of our mercantile marine, mainly owing to the immense advance made by the United States and Japan. In I9I4 we owned nearly $42 \%$ of the world's steam ${ }^{1}$ tonnage, but in I920 we owned under $34 \%$. In the

${ }^{1}$ In 1914 the percentage of sail to steam was just over 8 , but now it is under 6 . 
meantime, the States have raised their sea-going tonnage from about 2,000,000 to I2,400,000; Japan has raised hers from I,700,000 to 3,000,000. Excluding the shipping on the Great Lakes-where the States had more tonnage than on the high seas, our percentage has fallen between I9I 4 and I920 from about $44 \%$ to $35 \%$ and the U.S.A. percentage has risen from under $5 \%$ to over $24 \%$. Our total imperial tonnage now is about $20,600,000$, and the U.S.A. total is about $16,000,000$.

At the same time, the Mother Country is a tiny landabout $\frac{1}{11}$ the size of India, $\frac{1}{25}$ that of Australia, $\frac{1}{30}$ that of Canada; and her civilization is old. Some of her citizens cannot obtain work at all, although she throws open her doors somewhat gratuitously to foreigners; others see no hope of making a fortune; others, again, find no sphere in which to gratify their love of adventure. Consequently, year by year thousands (470,000 in I9I3) of her sons and daughters seek work, or fortune, or adventure, elsewhere.

\section{THE BRITISH ISLES}

\section{SURROUNDINGS}

Mathematic Position-Great Britain and Ireland are Islands in a Temperate Zone, at a distance of between $50^{\circ}$ and $60^{\circ}$ north of the Equator. In such a latitude the passage of the sun's rays over any given area is neither very fast nor very slow; and his light continues in summer for as much as seventeen hours a day, and in winter for not less than seven. Moreover, their insular position preserves these islands from great extremes of climate, and especially from any sudden change of temperature; it also guarantees an abundance of moisture.

These advantages are increased by the presence of the North Atlantic Drift and the S.W. Anti-Trade Winds. The influence of these two saves"Glasgow from having the climate of South Greenland; and, as warm 
water evaporates more easily than cold, especially in a latitude where distance from the equator is compensated by the slower passage of the sun's rays, it also gives the country much more than its fair share of moisture.

World Relations-Though so favoured in the matter. of rainfall, the British Isles are practically in the centre of all the Land on the Surface of the Earth. Four-fifths of the total 55,000,000 square miles of land are north of the Equator; and London will be found to be almost the exact centre of that area. Consequently, London will continue for ever to occupy, with regard to the world, the same position which Switzerland occupies with regard to Europe ; that is to say, it musthumanly speaking-always be a transit centre.

Again, the position of the British Isles on the eastern edge of the Atlantic not only gives them the full climatic and commercial advantages of the N.E. Trades and the S.W. Anti-Trades, but also brings them into close proximity to the Continent of Europe, the most civilized of all the continents up to the present age. This proximity is much more useful than contact would have been, for the English Channel enables Great Britain to remain quite independent of Europe, and yet to make a full use of it ; it enabled the English farmers to keep sheep in the Middle Ages, when war made sheep-farming impossible on the continent; and it has preserved England from many of the terrible plagues which have devastated the neighbouring countries. Even when it did not entirely stop invasion, it delayed it considerably, for in olden days ships were too few and too small for any large army to be transported suddenly to Great Britain from Europe. For instance, if William the Conqueror had not been delayed for half a year by the necessity of building a fleet, Harold would almost certainly have been victorious in the ensuing war; and, in that case, the civilising influence of the Normans in England would have been indefinitely postponed. 
The advantage of water-communication in the days when land carriage was conducted by pack horses, was very marked. It saved time, trouble, and expense,the latter especially when river and other facilities existed for shipping goods where they were made, and unshipping them where they were wanted. In recent years, when canals are cheaper, and railways are quicker, than any of the old means of communication, a plain must become an important natural line for commerce to move over; and, therefore, people have crowded on to the plain of Europe, especially that part of it which has both an open sea-coast and mineral wealth. That part is the one nearest to Great Britain-a fact which makes the German and the Belgian natural rivals of the British merchant.

Coast-Of course, the whole of Europe has a very large proportion of coast-line to surface, and this makes communications easy for all the European countries; but the advantages of this must be greatest to the nation which itself has the greatest similar advantages. The average proportion for Europe is I mile of coast to about 200 miles of surface ; that for Great Britain alone is I mile of coast to about 20 miles of surface. Consequently, while some places in Europe are nearly I,ooo miles from sea, no place in Great Britain is more than about 65 miles from sea.

Nor is this all. The configuration of Great Britain gives it a series of harbours vis-à-vis-the Clyde and the Forth, the Solway and the Tyne, the Mersey and the Humber, and the Severn and the Thames; and the distance across the country between these harbours is in no case more than roo miless, while in the case of the Scottish harbours it is not more than 40. Moreover, canals join all the last four rivers together; and the Thames and the Severn enjoy great tidal advantages, those on the Thames being practically unique. The latter has a double tide, the "Channel" tide entering the river at the same time as the "Irish" tide, though 
the latter is really I 2 hours behind the former, having had to travel round Scotland.

Four of the harbours look eastward, and four look westward; and the development of North America has made the latter more important than the former, always excepting London. Two hundred miles west of Land's End the bed of the Atlantic suddenly falls from Ioo to 2,000 fathoms-which is the average for the rest of the way across to Newfoundland ; and the fall causes a change of colour and of motion in the waves which is easily distinguished by a practised eye. This change is still useful to vessels sailing eastward, and it was much more useful to them in days when nautical instruments were roughly made, and when ships were so few that there was no fear of a collision except in the narrow waters of the English Channel.

Colonies-Great Britain has naturally, therefore, enjoyed special facilities for commerce from the time of Columbus; and, as her size has been too small for the maintenance of her increasing numbers, she has been obliged to send out Colonies of Settlement. These succeed best when set along Parallels of Latitude, where the conditions of life are more or less similar to those of the mother country; and this fact made the discovery of North America of immense importance to Europe generally, and to Great Britain in particular. Moreover, the enormous proportion of land north of the Equator confines the vast majority of the population to the same area; and the natural westward drift of this population brought its surplus to the eastern shores of the Atlantic, i.e. to the point from which the N.E. Trades " carry" across the narrowest ocean on the face of the Earth.

The narrowness of the Atlantic is itself a great advantage to commerce, and it is not the only advantage. Besides being the narrowest ocean, the Atlantic is also the most free from islands; and this freedom makes its navigation exceptionally safe, and increases the 
regularity of its winds. On the other hand, the possession of the few existing islands-most of which belong to Great Britain-is most useful to a commercial nation.

England alone has a coast-line of nearly 2000 miles in length, forming a rough triangle. The Eastern side of the triangle is composed of soft rocks which have weathered into a low monotonous line of shore, broken only by the estuaries of the rivers; and many of the rivers and the sea itself are, therefore, shallow and shoaly, and the tides over such a surface are slight and regular.

The East Coast-There are four estuaries of importance along this coast-those of the Tyne, the Tees, the Humber, and the Thames. The Tyne and the Tees empty close to one another at opposite ends of a small stretch of Magnesian Limestone, which is backed by, rich and extensive coal measures. Both the rivers open towards Denmark and Germany, and from both the transport of coal and other wealth is easy and cheap by sea. Newcastle and a number of suburban towns occupy the banks of the Tyne for I2 or I3 miles, and manufacture glass, chemicals, and the metals-iron, lead, and zinc-which were originally found along the deep river valleys of Northumberland. The Tees drains the great Cleveland iron and salt field, and the trade in these two commodities has given an extraordinary rapidity to the growth of Middlesbrough. Stockton, which used to be the port of the Tees, has been outstripped by Middlesbrough, because the former is the farther up the river. In connexion with the general trade of these two estuaries, large shipbuilding yards sprang up at Jarrow and Sunderland, and a large sail-making industry has its centre at Hartlepool.

The other two estuaries are those of the Humber and the Thames; and, between the two, Yarmouth Roads afford a safe anchorage. The Humber is the only opening through a long line of coast-uplands; and it leads up through the plain cnclosed by these uplands towards 
the coal-field of South-West Yorkshire. Consequently, the port of Hull has a large trade both in agricultural and in manufactured commodities, though it is too far from the coal mines to command all the coal traffic. From its position Hull almost monopolizes the English trade with the Baltic. It has also a large fishery, in which its nearest rival is Great Grimsby, on the south bank of the Humber. It is a great oil-seed port.

The Thames is the most important, as well as the largest, river in England. As it rises at a height of little more than 300 feet-close to the Severn-and yet runs for more than 200 miles before entering the North Sea, its navigation is not impeded by swift currents or rapids. The estuary opens into the North Sea, near its narrow exit through the Straits of Dover, through which practically the entire foreign shipping of Central Europe is compelled to pass; and the Goodwin Sands shut in the largest natural refuge for shipping in the world. London may be said to cover an area of nearly 700 square miles, and to contain a population of $7,000,000$ ! The great drawback to the port is its distance from coal and iron; but the river is navigable by the largest vessels afloat to the very heart of the city, its mouth is directly open to the great harbours of Rotterdam and Antwerp, and the city is in direct communication by rail, road, or canal, with every inland part of Great Britain. Harwich, which is just off the northern limit of the Thames estuary, is a packet station for passengers and goods to and from the Continent.

The South Coast, or base of the triangle, has no important rivers, but there are three very important harbours. Two of the three, Portsmouth and Southampton, lie behind the Isle of Wight, which thus defends the approach to them from both storm and foes. Portsmouth, which is entirely landlocked, is the chief naval arsenal of the kingdom. Southampton has a very large passenger service, mainly with South Atlantic 
ports, and ocean "Liners" can now lie up to a railway quay. The third harbour, Plymouth, is on the beautiful estuary of the Plym and the Tamar, and is protected by a huge breakwater. The deep-sea approach from the south-west is guarded by the Eddystone Lighthouse.

Dover, Folkstone, and Newhaven have a large " crossChannel " trade, though they can in no sense be called natural harbours; and Falmouth, which is a real harbour, is too far out of the way to be of much importance.

The West Coast harbours are more important than even those of the east, chiefly owing to the ever-increasing trade with North America. Much the finest estuary is that of the Severn which contains the three great harbours of Bristol, Cardiff, and Swansea, and which has an exceptionally high tide. Swansea and Cardiff are on the South Wales coal-field, and Cardiff exports more coal than any other port in the world. The presence of copper and iron in the neighbourhood, and the ease with which they can be imported, especially from Spain, have given rise to huge metal industries at both places.

Between the North Wales and South Lancashire coal-fields is the estuary of the Mersey. There is a rather dangerous bar across the river, which has to be kept constantly dredged, but the enormous coal and manufacturing wealth of the surrounding country have made Liverpool in some senses the most important city in the country. Most of the Liverpool trade is with foreign countries, but the city shares with Holyhead the greater part of the Irish trade-though the new port of Fishguard is affecting the trade of both.

The finest harbour of all on this West Coast is, however, that of Milford Haven. It is about 200 miles nearer than either Iiverpool or Southampton to America ; it avoids the most dangerous part of the present searoute to America; it has a harbour the entrance to which is two miles wide, and perfectly free from any bar; and the demand for a line of good steamers 
between Canada and France is sure eventually to make Milford Haven a calling port for vessels on that route, especially as there will no longer be any necessity to call at Queenstown.

The Coast of Scotland is so deeply indented that its total length is several hundred miles more than that of the English coast ; and the western part of it is even much more broken than the eastern, owing to its being exposed to the force of the Atlantic waves and winds. Indeed, all the softer portions of the west coast have been washed away, leaving an outer barricade of islands and an inner wall of very hard rock, pierced by numbers of sea lochs, in which the herring fishery is very productive. The eastern coast, on the other hand, is mainly formed of sandstone and clay, which are easily worn away-especially round the mouth of a rapid river, e.g. the Tay-into deep, wide estuaries.

The West Coast-The principal port of Scotland is Glasgow, which is on the southern portion of the west coast. It stands on the river Clyde, the Firth of which is a large and very beautiful expanse of sea encroaching into the Lowland Plain and having canal communication with the east coast. Within the memory of living men the Clyde at Glasgow was fordable on foot. Now, as the result of persistent and extensive dredging operations, the largest ocean-going vessels can be berthed in the very heart of the city.

On the East Coast the Dee, the Tay, and the Forth supply three good harbours ; and Cromarty Firth gives perfect shelter in stormy weather. The importance of Aberdeen is largely due to its position at the opening of two valleys commanding the internal trade of the north of Scotland; but Dundee and Leith owe their importance almost entirely to their harbours. The Tay pours into the sea a greater volume of water than any other river in Great Britain, and is navigable above Dundee as far as Perth; but Dundee is nearer than Perth to both the ocean and the coal-fields of the central plain. 
The easy communication with the Baltic ports gave Dundee originally almost a monopoly of the import of flax and hemp, and this import also attracted the jute trade to Dundee.

Leith, though the port of Edinburgh, and immensely improved during the War, is of less importance than Dundee. The Forth is navigable far above Leithindeed, up to Stirling for small vessels; and the coalfields of Alloa on its north bank, and those of Midlothian and the ironworks of Falkirk on its south bank, have attracted a considerable population.

The Irish Coast is also deeply indented, especially on the western side, where it is exposed to the full force of the Atlantic; and no part of the country can be much more than fifty miles from deep sea. It differs from the coast of Great Britain, however, in several important particulars. The islands which fringe its northern and western portions, are-unlike those fringing the shore of Great Britain-too small to give much protection; there is only one good river emptying through the west coast, the Shannon, and that is too far from any populous centre for its port, Limerick, to have any great trade. Galway, situated on a splendid harbour, which is protected from the Atlantic storms by the Aran Islands, is obviously the nearest British port to the United States, and so may become now the starting point for a line of steamers to New York.

The eastward rivers are too small to form good liarbours, too much sheltered to have their estuaries kept clear of sandbanks by the rush of the waves, and prevented by the intervening English ports from having any real Continental trade. Indeed, the only natural harbour on the east coast is that of Strangford Lough, which is shut in by the Ards Peninsula; Dublin Bay, througl which almost all the foreign commerce enters the country, is spoilt by sandlanks.

At the extreme N.L. and S.W. conners of the country, 
however, there are two very important harbours. Belfast owes its importance to its position on the Ulster iron-field, and its close proximity to the Scottish coal and iron; Cork is completely landlocked, and stands very near the present route of the Ocean Liners between England and America.

\section{SURFACE}

Natural Units-The division of Great Britain into three areas under different names is not altogether artificial. The disproportion between the length and breadth of the country, and the physical obstacle presented by the Cheviot Hills, gave Scotland naturally a separate political existence; and the protection of the Cambrian mountains, and the uninviting barrenness of the Welsh moors, favoured the conservation of a separate kingdom west of the Severn.

Great Britain may be divided into belts of land, running from S.W. to N.E. The first includes the Scottish Highlands, and is bounded on the south by a line from Helensburgh to Stonehaven; there the barren slopes of old crystalline rocks are succeeded by the fertile Lowlands of carboniferous limestone. These Lowlands break on to the grassy downs which cornmence a belt of hill and mountain, bounded on the east by a line from Berwick to Exeter. All the rest of the country, i.e. the entire East and South of England, is a plain, covered by low limestone or chalk hills, over the southeastern portion of which the soil is newer and more fertile than elsewhere.

Relief Rains-The evaporation off the warm North Atlantic Drift is, therefore, met by mountains along the west coast, so that the condensing medium is as near as possible to the point where the wet Anti-Trades first touch land. These mountains, however, expand towards the north, not the south; and, therefore, not only is the south-eastern area the most fertile, but also 
it had no physical barrier to check invaders from the South or the East who were tempted by that fertility. At the same time, the mountains in the North and the West gave a safe retreat to the natives; and thus conquest was always gradual, and the recesses of the mountainous districts became unnaturally-well explored.

The gradual progress of conquest, e.g. in the case of the Saxon invaders, enabled the hostile parties to become acquainted with one another; and the conditions of war caused the number of native young men to be continually decreased, while the invading army was being continually recruited by young men from the Continent. Consequently, as the proportion of native young women increased, they compulsorily married amongst the invaders.

The mountains in which the natives took refuge, werc along the west coast; and against them on 225 days out of every 365 the S.W. Anti-Trades bear their burden of rain. Thus tin, copper, coal, iron, slate, salt, and lead were washed bare in the Cornish, Devon, Mendip, Cotswold, Cambrian, Pennine, and Lowther hills ; and as the rain was heaviest where the ground was highest and nearest to the sea, the minerals of Cornwall, Wales, and Cumberland were laid bare before those of Gloucestershire, Lancashire, and Lanarkshire.

Having deposited their burden of rain on the west of these mountains, the winds travel on eastward much drier; and thus extensive areas on the tablelands of Wiltshire, Warwickshire, Leicestershire, and Yorkshire, grow only the short grass which is specially suited to sheep. At the same time, on the Lias plain west of the great Chalk Range from Cheddar to Stilton, the richer grass made the counties of Somerset, Gloucester, and Leicester-like the part of Cheshire which is on Lias -famous for checse; while the Bunter Sandstone west of the Pennine Range and of the Dorset Heights made Cheshire and Devonshire famous for butter and cream.

The country is so narrow, however, that the variation 


\section{THE BRITISH ISLES}

in the rainfall is not very great; the average rainfall of London is 24 inches, that of Liverpool is 35 , and that of Plymouth is 40 ; and, considering the latitude, the rainfall is too great and too continuous for wheat everywhere except in the East and East-Centre of England, e.g. in the basin of the Thames, where it supplies the biscuit factories of Reading. Barley flourishes much better, e.g. in the basin of the Trent, where it supplies the breweries of Burton, and in the basin of the Tay, where it supplies the distilleries of Strathmore.

The Narrowness of the Country further accounts for the exceptional suitability of inland towns like Manchester and Leeds for spinning cotton and wool, which, in a country as dry as South Africa or the Argentine, becomes a practical impossibility; and this caused the dense concentration of population on the Lancashire and Yorkshire coal-fields, although they had originally no direct sea communication. Hardware industries have grown up along with-partly owing to-the textiles.

At the same time, this narrowness would have been a great drawback if there had been mountains either along the east coast or down the centre of the island; but, as it is, the position of the mountains along the west coast makes an excellent watershed for comparatively long flowing rivers towards Europe, and flowing over such a gradual slope that they are slow enough to be navigable, and not to bring down too much sand, and not to injure agriculture by floods. Consequently, the harbours at their mouths admit the largest vessels afloat, are kept open with little dredging, and have no obstacle to rail and canal communication inland; and the undulating surface of the slope hinders the formation of marsh, and concentrates the rainfall into great rivers.

The presence of the mountains in close proximity to the sea has another important aspect. They are naturally unfitted for tillage, the products of which are light in bulk; but they are rich in minerals, which are so heavy that water carriage for then is a necessity. 
The manufacturing districts are directly connected with the mineral deposits, especially of coal and iron; and thus goods are made on or near the sea-coast, with the exception of those made in the Leeds and Birmingham districts.

The distribution and collection of goods inland is carried on by a magnificent railway system radiating from London. Special local services, e.g. between Manchester and Liverpool, or between Glasgow and Edinburgh, are said to be unrivalled in the world. Indeed, the excellence of the railway and the coasting services has led to the partial neglect of the canal service of the country.

\section{INDUSTRIES}

The Industries of the United Kingdom may be said to be five in number-Agriculture, Fisheries, Manufactures, Mining, and Trading; and in the past the Agriculture has been of the greatest importance to ourselves, and the Trading has been of the greatest importance to foreign nations.

At present our commercial position is, on the whole, as good as that of any other country; but we have come to a critical point, and it may be well to inquire into the character and the causes of our present position.

Our Past Prosperity has been due to a variety of causes, of which the chief are-the geographical position, the climate, the abundance of coal and iron in easily accessible places and in workable forms, the excellent harbours, the fact that almost all the most valuable mechanical inventions were either invented or first adopted in this country, the character of the people, the abundance of capital, the extent of our colonies and the necessity of keeping up communication with them across the various oceans, a free-import policy, and the extent to which the English language is used by the great producers of raw materials throughout the world. 


\section{THE BRITISII ISLES}

At the same time, it is certain that our trade has in some directions reached its farthest limit. For instance, several continental nations are now producing at home goods which they formerly purchased from us; and this will be increasingly the case. Moreover, other countries-partly as a fiscal necessity, partly from economic ignorance-are imposing, and have imposed, high tariffs which paralyse their trade; and thus our industries decline at the same time that their industries are in an artificial and utterly unhealthy condition. In a few instances, however, e.g. with parts of South America, our trade might be expanded to an almost unlimited extent.

Division of Labour-These tariffs are, of course, absolutely inconsistent with any scientific Division of Labour ; and this principle is becoming stronger every day. Indeed, it is likely to revolutionize some of the industries of Great Britain. For instance, it is recognized that Canada can produce wheat, New Zealand mutton, and Australia wool, better than other competing countries; and, as has already been pointed out, ocean carriage is cheaper than any other form of water carriage; for a Shipping Company has not to buy the site for its " permanent way," nor to maintain it, nor to pay rates and taxes on it ; and as "empty" vessels must have ballast, heavy goods are often carried across the Atlantic at a comparatively insignificant cost.

Consequently, the question of home industries has to be discussed in the light of these very significant facts - that other countries can produce certain things which have hitherto formed a very important item in our home trade, that they can produce them better and cheaper than we can, and that the long distance transit is all in their favour so long as the goods in question can come by sea. Narrowed down to the utmost, then, the question at issue is practically-What can we produce well at home which cannot be imported? 
And subordinate to this is the question-What are the necessaries of ordinary life in this country?

Food-Shelter and Artificial Heat we can easily provide ourselves with, and our attention may be confined at present to Food and Clothing. Food may be limited to milk, bread, and meat; but fruit and fish are desirable, and tea has become an "acquired" necessity. In the same way, Clothing may be limited to cotton and wool ; but silk and flax are also used for it. Now, it is obvious that tea, silk, and cotton cannot be produced at all in this country; and it is being gradually forced on our notice that our climate is too fickle, our land too dear, and our soil too much in need of scientific culture, for us to be able to compete with other countries, e.g. Central Canada, in the production of wheat. The same is largely true with regard to meat, mainly because of the increased price of cattle"cake." This would be lessened, and a better profit would be made off poor land-with the present price of wheat-by tilling it.

Milk-Broadly speaking, the agricultural future of the country depends on grass and market gardens on a large scale, especially the production of potatoes; and the grass is very much the more important of the two, but it should not be used for the production of cheese and butter. The use of machinery, the free import of wheat, social advantages, and other causes are drawing all our population into the towns; and the future of the whole race depends on the success with which we face the question of providing the enormous and rising infant population of our huge cities with plentiful supplies of good milk at a price within the reach of all, even the very poorest. Now, milk will not travel; and, even if it could, it has a most unfortunate power of absorbing noxious germs and clements (e.g. from oranges, smoked bacon, or tobacco, standing in the same window). Consequently, imported milk would never be quite free from suspicion; and, as a matter 
of fact, foreign competition can scarcely enter into the trade except for " condensed" milk.

Hundreds of millions of gallons of milk are produced annually in the country; but even if all were used directly as food, and if every one had a fair share, that share would be considerably less than one pint a day. As a matter of fact, 400 or 500 million gallons of the whole amount are consumed in the manufacture of butter and cheese, both of which can be produced better and much cheaper elsewhere (e.g. in Ontario) ; and, on the other hand, in I9I9 condensed milk was imported to a value of $f_{14}, 000,000$. It is, therefore, obvious that, if the question were faced boldly and scientifically, there would be a very large increase in the number of milch cattle in the country. The sanitary condition of dairies and the cleanliness of the workers in them might also be immensely improved.

Fish-With regard to Fishing, it is becoming more and more the practice for it to be carricd on at a distance from shore. For instance, the shores of Iceland are regularly visited by British ressels engaged in the cod fishery. This practice, of course, brings us into relations -sometimes unpleasant-with Foreign Powers; and it has revolutionized the social conditions of the industry.

Every small port has a few craft engaged in fishing, but the great fisheries of the country are concentrated in a few places; and England possesses more such places than Scotland, and Scotland more than Ireland. The conditions which make a great fishing centre are three in number-proximity to the best markets, proximity to the best fishing-grounds, and proximity to the fishermen's homes ; but the last point is becoming of less importance in proportion as improvements are made in the vessels employed in the industry. Moreover, as the "season" varies at different places, the same boats-if supplied with means of quick movement -can "follow the seasons." For instance, Yarmouth boats will be engaged in the mackerel fishery off the 


\section{A COMMERCIAI GEOGRAPHY}

south-west coast of Ireland, in the pilchard fishery off Cornwall, and in the Manx or Shetland herring fishery; and in each case the "centre" is a port from which the distribution of fish can be conducted with great speed and regularity and cheapness-so cheaply that cost of carriage does not add anything like Id. per lb. to the cost of the retailed fish.

Great Grimsby is " the metropolis of the British fish trade," and possesses the same advantages over Hull that Harwich does over London; it is in purer water and nearer the fishing-grounds of the Dogger Bank, and the introduction of "welled" smacks has made the condition of the water a matter of great importance.

London, as the ideal centre for distribution, collects practically the whole "catch" of the east and south coasts, in Billingsgate market; but any port which is well provided with railway accommodation, and within easy reach of ice (e.g. Leith, which obtains constant supplies of ice from Norway), would be almost equally good. Salt and barrels are also nccessities, the latter especially in connexion with the Scotch herring fishery, three-quarters of the whole Scotch herring catch-as a rule-being pickled for export. Besides the ports already referred to, Aberdeen, Plymouth, Stornoway, Wick, Fraserburgh, and Peterhead are important centres. In I9I8 fish landed on the coasts of the British Isles was valued at over $£ 21,000,000$.

Mining and Manufactures are very closely connected, as the great mineral wealth of the country consists in coal and iron, i.c. fuel and machinery ; and, fortunately, in Great Britain these two most important minerals are found side by side, near the sea, and near plentiful supplies of limestone for flux. The deposits in Ireland are not large, and are far apart. In England there are thrce, and in Scotland two, chief coal-fields; and, though Wales only possesses one important field, that one is cxtremely valuable.

"Newcastle"-In the north of England there is the 
Newcastle coal-field, which extends along both the Durham and the Northumberland banks of the Tyne. On the north bank stand Newcastle itself, North Shields, and Tynemouth; and on the south bank stand Gateshead, South Shields, and Jarrow. The coal lies actually along the river; and the ease with which it can be worked and exported, has made the Tyne ports famous throughout the world for coal. Indeed, they export more coal than any other centre except Cardiff; and this trade gave rise to the very large shipbuilding industry which flourishes on the Tyne and the two neighbouring rivers, the Wear and the Tees. A great proportion of the coal is now used in the ironworks and shipyards of Newcastle, Sunderland, and Middlesbrough ; and in the smaller town of Hartlepool a valuable rope and sail-cloth industry sprang up in connexion with the shipping. The coal and the shipping have also given rise to an enormous trade in chemicals-soda and sulphuric acid. The Durham coke is the best in the world.

"Textile"-Between the Mersey and the Humber lies the great Lancashire and Yorkshire coal-field, known also as "the Cotton and Woollen." The coal lies along both sides of the Pennine Range, and extends to the south of it into Derbyshire and Nottinghamshire. As that range is much nearer to the west than to the east coast, the western coal area is much the more convenient for shipping; and this fact, coupled with the convenient situation of Liverpool with regard to North America, and the moist climate of the west coast, drew the cotton trade to South Lancashire. The wool trade depended at first entirely on home supplies of wool, and therefore naturally preferred the Yorkshire moors.

Cotton-Manchester is the centre of the whole cotton trade; Bolton, Oldham, Bury, Rochdale, and Stockport are all engaged in spinning, with populations varying from 180,000 down to 60,000 ; Preston, Blackburn, Accrington, and Burnley are the chief weaving centres, the first producing the finest and the last the coarsest 
fabrics. Relatively, more dyeing and printing are done in Lanarkshire than in Lancashire. Distribution of the manufactured goods by land is provided for by an excellent railway service, the L. \& N.-W.R. main line from London to Glasgow running through the coal-field, while the Lancashire and Yorkshire and the Great Central provide excellent communication across the Pennine Range from the Mersey to the Humber basin. Liverpool is at present the great port of the whole district ; and, in connexion with the enormous population behind it, it almost monopolizes the American grain and cattle trades. The imports of timber and, of course, of cotton, are also very large ; and naturally shipbuilding, with the usual metal industries, is important. Widnes has the chief copper-smelting works in England; and St. Helens shares with Newcastle the glass and chemical trades.

Wool-Leeds and Bradford are the centres of the woollen trade, and are surrounded by a number of large towns such as Huddersfield, Halifax, and Wakefield. There is a considerable Division of Labour. Leeds and Huddersfield make broadeloth ; Bradford makes alpaca, mohair, and woollen damasks; Halifax makes flannel, rugs, and carpets. Leeds has also a linen trade, which sprang up in connexion with the flax cnlture of Yorkshire; but Barnsley has a more special interest in the linen trade, and normally draws its supplies from Russia via Hull. There is an excellent railway service through the country from London to Scotland, the East Coast Joint Stock running via Doncaster, and the Midland via the cutlery town of Sheffield; and the excellence of the Midland mineral traffic, and the distance of the coal-mines from the Humber, cause the surplus coal to be sent to London chicfly by rail.

"Midland"-The nearest coal-field to London, however, and the one best provided with canal communication, is that which lies between Coventry and Stoke. The northern part of it is known as the Potteries, and draws its supplies of china clay from the clecayed granites 


\section{THE BRITISH ISLES}

of Devon and Cornwall, through-communication being provided by the Great Western Railway via Bristol. The southern part of this Staffordshire coal-field is known as the Black Country. It is shut in on two sides by the Severn and the Trent, and contains the great cities of Birmingham and Wolverhampton, which are almost entirely devoted to metal and hardware industries. Wolverhampton, with the neighbouring towns of West Bromwich and Walsall, specializes in iron, but almost every kind of metal work in the world is found represented in Birmingham. Machinery and munition of war bulk most largely; but wire, nails, and screws, scientific instruments, gold and silver plate, and pens, are also very important items. Several thousand tons of Swedish iron are used every year in the production of pens alone. Coventry produces bicycles, sewingmachines, motor-cars, and aeroplanes.

Smaller Coal-fields-Besides these three great coal areas, there are several small fields in different parts of the country. The most important are two which lie respectively along the coast of Cumberland and along the south-west course of the Severn. The former lies close to a very valuable deposit of red hematite iron in the Furness district of North Lancashire; and, owing to this, Barrow, a port between the mouth of the Duddon and Morecambe Bay, has developed, with almost unique rapidity, into one of the largest shipbuilding centres in Great Britain. Whitehaven is the chief coal port, but Maryborough and Workington also export.

The coal on the west bank of the Severn, i.e. in the Forest of Dean, is now more valuable than that on the east bank, i.e. along the Avon, as the latter is very difficult to work; but the latter has been, in the past, of even more use to the shipping, sugar, and tobacco industries of Bristol than the former has been to the tweed manufactures of Stroud and other towns along the foot of the sheep-ranged Cotswold Hills. Bristol was a place of very great importance in earlier times, 
when it was a distinct advantage to a port to be some way up a river; and-through its outports of Avonmouth and Portishead-it may again rise to its former position if full use is made of the opening for developing our trade with South America.

Wales-Bristol has, however, some formidable rivals on the west bank of the Severn. Along that bank, in the counties of Glamorgan and Monmouth, stretches what is known as the South Wales coal-field; and, as it contains very valuable supplies of anthracite coal, the ports of Cardiff, Newport, and Swansea have a great advantage over all other ports in Great Britain. Indeed, Cardiff exports more coal than any other port in the whole world; and its dock acreage, in the Barry and Penarth Docks, makes it the third port in the United Kingdom. In I84I its population was Io,000; it is now over I80,000. In addition to its huge coal trade, Cardiff-like Swansea, Llanelly, etc.-- manufactures an enormous quantity of tin-plate and zinc-plate, chiefly for export to the United States. Swansea is, however, specially the headquarters of the copper-smelting industry of the country, and at Merthyr Tydvil there are large steel works; but almost all the copper and the iron ore are imported, mainly from Spain. Some of the tin, on the other hand, still comes from Cornwall and Devon, though they now produce less than 5 per cent of the world's output.

The Scottish Coal-fields lie in the narrowest and the lowest part of the whole country, a fact which gives them particularly easy communication by sea, rail, and canal. The western field lies partly along the Ayrshire coast and partly along the Clyde. In Ayrshire it feeds the ironworks and woollen factories of Kilmarnock, the latter of which arose in connexion with the sheep-farms along the Haughshaw Hills; and the Ayrshire ports of Troon and Ardrossan send large supplies of coal to Belfast. The Clyde ficld has made Glasgow the second city of the Empire in importance, and the sccond in 
the United Kingdom in actual numbers. It is the centre of the cotton and iron industries, and transacts an enormous proportion of the foreign commerce of Scotland. This commerce is largely fed by a number of towns in the immediate neighbourhood, the whole of which are abundantly supplied with coal and iron. For instance, Paisley manufactures thread and shawls, Renfrew silk and muslin, and Johnstone linen, while Airdrie, Hamilton, Coatbridge, Rutherglen, Wishaw, and Motherwell mine coal and iron. Glasgow itself has very large engineering works and shipbuilding yards. In the latter industry Greenock, Dumbarton, and PortGlasgow also share; and its position at the very mouth of the river has also drawn an extensive foreign trade to Greenock, sugar and timber being the staples. Greenock has a special industry in sugar-refining.

The eastern field, which is the less important, lies along the two banks of the Forth, and its southern area stretches through the Lothians. To the east of the Pentland Hills there is little coal, and that is mainly confined to the west of Haddingtonshire; but to the west of the Pentlands there is abundance of coal, specially round Bathgate, and there is also a rich oilshale field. West Calder is the centre of the latter, from which wax and paraffin oil are made. Leith is the chief port of the district; but Grangemouth is also important, being near the iron and coal centre of Falkirk. The northern area stretches through the counties of Clackmannan and Fife, and its produce is exported from Alloa and Kirkcaldy to the Baltic and the industrial towns of East Scotland. Dunfermline, which stands in the centre of the area, has an extremely important linen trade, millions of yards of table linen alone being manufactured there annually.

Ireland has two useful coal-fields; but both of them are small, and neither is conveniently situated. The Leinster field, where the coal is of a very good quality, has its centre at Kilkenny. The Munster field lies along 
the lower course of the Shannon, and supplies the little port of Limerick.

The only manufactures of any real magnitude in Ireland are found in Ulster, where the presence of iron, the suitability of the soil for flax, and the proximity of the Ayrshire coal-field, have developed a very large linen industry in Belfast and a number of much smaller towns in Antrim, and in Londonderry and Armagh.

Other important industries in the country which are not so directly connected with the coal and iron fields, are those in slate, salt, and leather. The slates are quarried mainly in Wales, at Bethesda, Llanberis, and Festiniog; the salt is obtained from the rock-salt mines of Cheshire and Worcestershire, especially from Nantwich, Middlewich, and Northwich, and in Cleveland; Northampton is the centre of the boot and shoe trade, and Walsall of the harness trade.

\section{THE DOMINION OF CANADA}

Canada is at present the most important of all the British Colonies, partly because of its geographical position and partly because of its size. It is the largest continuous expanse of land in the world under one flag except China or Russia. When compared with its continental and oceanic neighbours, it is found to be larger than the United States, and very nearly as large as Europe ; when compared with the Mother Country and her Empire, it is thirty times as large as the United Kingdom, and constitutes almost half of the whole Empire.

\section{SURROUNDINGS}

Coasts - Canada has sea on three sides; and even on the fourth side, i.c. the south, there is a large area of water in the form of fresh-water lakes. The sea on the north, however, is rendered useless for commerce by the climate. This is specially to be regretted because the 
islands with which it is studded, are rich in mineral wealth, composed of rock which "weathers" well, and provided with excellent natural harbours.

In the north-east corner, however, there is a very important area of sea known as Hudson Bay. It is several times as large as the area covered by the United Kingdom and the Irish Sea, and its effect on the climate south of it is very marked. Its coast-line is comparatively valueless, owing to the climate; and, though the level of the country offers extraordinary facilities for railway construction up to Lake Winnipeg, the rivers which empty into the bay are so shallow that even the lightest birch-bark canoe has to be unloaded from time to time and carried over shoals. Moreover, as this is due mainly to a " natural " cause-the excessive evaporation off the central lakes, from which the Churchill and the Nelson draw their waters--there is no hope of any real improvement being made in the water-way without canalization.

The only real difficulty with regard to the Bay itself is the approach from the Atlantic up Hudson Strait. The northern end of the latter is in the latitude of the White Sea, and is therefore shut by ice for more than half the year. Strong steamers specially built for the traffic can, however, keep up a continuous service between Fort Churchill, Fort York, Port Nelson, and Europe for at least four months in the year, including the month immediately after harvest; and a line of rail is now being constructed from Winnipeg to Fort York. The advantage of the route, as far as distance is concerned, is very great. Owing to the much smaller circumference of the earth in the more northerly latitude, Fort York is nearer to Liverpool than Montreal is, although the latter is $20^{\circ}$ farther east than the former ; and the journey from Liverpool to Winnipeg is about a thousand miles shorter via Fort York than via New York.

The East Coast is at present the most important of the three, owing to the fact that colonization came from the 
east; but it has really fewer advantages than the west coast. Davis Strait is so broad and so deep that it admits a large quantity of ice through into the Atlantic ; and thus the coldness of the Labrador current from the Arctic Ocean, the freshness of the St. Lawrence water, and the amount of land round its mouth; cause that river to be ice-bound for four months every year. Even when the river is open, the navigation is not very safe. Two of the three entrances to the Gulf-Belle Isle Strait and the Gut of Canso-are very narrow; and the meeting of the warm Gulf Stream with the cold Labrador Stream causes dense and frequent fogs over the approach to the Gulf.

The route has, however, immense advantages. The river comes through so many lakes that its waters, though fresh and therefore easily frozen, are too pure to deposit any bar at the mouth of the river; and the bed has been dredged so as to admit vessels drawing 30 feet as far as Montreal, i.e. I,000 miles from the Atlantic. Thus Montreal, which is about 300 miles nearer to Liverpool than New York is, has been made a fresh-water ocean port. Moreover, the river has been so perfectly canalized and provided with ship-canals round its numerous rapids, that ocean vessels can now ply direct between Liverpool and Fort William or Duluth, the great grain ports in the extreme west of Lake Superior, i.e. 2,000 miles from the Atlantic.

However, Montreal, like the less important harbours of Quebec and Charlottetown, is ice-bound in winter ; but on the Atlantic shore two ports--Halifax and St. John-are kept open the whole year through by the influence of the Gulf Stream. Halifax is the better of the two, and has thus become the winter port of Eastern Canada. It stands on the ocean, not on a bay; its harbour is very large, deep, and safe; the anchorage is excellent; the entrance is protected by M'Nab Island; the place is strongly fortified, and garrisoned by Canadian troops; no charge is made for dockage; it 
is connected with all parts of Canada by rail or canal ; it has richer land round it, and is nearer to coal and iron. The inferiority of St. John lies in the absence of coal and the extraordinary tidal conditions. The shape of the Bay of Fundy, the smoothness of its " trap " floor, and the pressure of the Gulf and Labrador Streams, cause the tide to rise faster and higher than anywhere else in the world.

The west coast seems to have a great commercial future before it. Behring Strait is too narrow and too shallow to admit much ice into the Pacific; the warm Japan Stream and Anti-Trade winds bear constantly towards it; and there are no large openings such as the Gulf of St. Lawrence. Consequently, it is never icebound; and, as it is admirably supplied with coal and iron, its harbours must become extremely important. They are three in number-Prince Rupert, Vancouver, and Victoria (Esquimalt). Vancouver, like New Westminster, is on the mainland, Vancouver being the better of the two. It has a large, deep, and safe harbour on Burrard's Inlet; it has immense supplies of timber. metal, and food; and, as the terminus of the Canadian Pacific Railway, it can always obtain coal easily if not very cheaply. It cannot, however, rival-simply as a port-the Grand Trunk Pacific terminus of Prince Rupert.

Esquimalt, the port of Victoria, is one of the great harbours of the world. It stands on the Juan de Fuca Strait, sheltered from the south-west gales by the Olympian Mountains. It enjoys a beautiful climate; its sea-approach is straight and deep ; its harbour is large and land-locked; its wharves are very extensive and lit by electricity; it has most valuable forests and coalmines in its immediate neighbourhood, and accessible by water; it commands all imports from the west, e.g. tin (for the salmon canneries) from the Malay Peninsula, and thus has come to control all exports, e.g. the salmon ; it is the most convenient harbour for the sealing vessels, and thus has developed a shipbuilding industry. It has 
all the advantages of Vancouver, except continuous communication with the C.P.R.

The fisheries off the west and the east coasts are very valuable, the chief products being salmon, cod, and herring. The salmon are most plentiful on the west coast, where they specially frequent the Fraser river. They are caught by Indians, and tinned by Chinamen; and the river is so clear, owing to its having come through so many lakes, that the fishing can be carried on only at night. The cod and the herring seem to prefer the colder waters of the Atlantic, and are found on the banks over which the Labrador current deposits the millions of minute organisms that it brings down from the Arctic Circle. The east coast has also easier access than the west both to markets, e.g. New York and Boston, and to supplies of ice; but the smoothness of the water on the west coast greatly facilitates the fishing operations there.

The southern boundary of Canada is partly artificial, but also partly natural-the Great Lakes. These lakes are all connected with each other by the St. Lawrence and ship-canals; and the trade on them is simply enormous. Lake Superior alone is as large as Ireland; the annual tonnage through the Detroit passage, though the river is ice-bound for four months, is much more than the combined tonnage of London and Liverpool ; and the actual number of vessels using the St. Mary Canal is three times as great as that of vessels using the Suez Canal. The navigation is, however, rather dangerous. The air over such a huge extent of water, under a cloudless sky, is naturally very moist; and thus warm dry winds from the south are apt to cause dense fogs, and cold dry winds from the north are apt to cause terrible snow-storms.

\section{SURFACE}

Canada lias four natural divisions-a Forest Region in the east, a Prairie Region in the centre, a Mountain 


\section{THE DOMINION OF CANADA}

Region in the west, and a Frozen Marsh Region in the north ; and the Prairie Region is much the most important of the four, owing to its intimate connexion with the food question in the Mother Country. Central Canada can produce a great number of different commercial plants with exceptional success, but the great product is wheat.

Central Canada is an enormous plain of very slight elevation, which separates the forest region of the Atlantic sea-board from the mineral wealth of the Rocky Mountains. It slopes almost imperceptibly from the south, i.e. the U.S.A. frontier, down to the Arctic Ocean ; but there are three distinct "steps" running across it in the other direction, i.e. from the Rockies down to the level of the Great Lakes. The first of these from the east is the Red River plateau, which is practically Manitoba, and its height averages about 800 feet above the sea, rising on the international boundary to about I,000 feet. The middle "step," which includes the eastern half of the Province of Saskatchewan, is twice the height of the first ; and the third, which includes the whole of Alberta and the western half of Saskatchewan, rises from about 2,000 feet to 4,000 feet at the base of the Rockies.

The southern part of the North-West Territories, e.g. the Great Slave Lake basin, has some very valuable grain land ; but the latitude and the absence of communication make agriculture rather precarious and transport very expensive. Consequently, at present the great wheat-fields of Canada are confined to latitudes corresponding to those of the United Kingdom.

The predominant formation over this area is cretaceous, with patches of other rock, including volcanic; and a glance at the map will show that the whole area is well supplied with rivers, some of them very long, and all of them flowing towards the Atlantic coast, i.e. towards Europe, the greatest market in the world. 
Relief Rain-The most conspicuous feature on the map is, however, the mass of mountains along the western sea-board of the country; and a further examination will show that these mountains are broad, very high, increasing in height towards the south, containing no isolated cones, and cut across by very deep depressions. As they run north and south near the sea, they will present an almost full face to any west or southwest wind; such winds come off the Pacific Ocean after a course of hundreds of miles over warmish water and under a hot sun, and are therefore saturated before they reach land; and the mountains meet them at the very coast-line, i.e. when they are at their wettest. The precipitation of rain is, therefore, very heavy and violent on the lower elevations; and, as there are no volcanic cones, the mass of snow precipitated on the higher elevations has numerous depressions and valleys in which it can solidify into glaciers. These glaciers guarantee a constant supply of water to all rivers which rise in them, and the volume of water in these rivers will be greatest about harvest time, when the heat has gained most power on the ice; and, as the mountains increase in height towards the south and have deep depressions across them from east to west, the greatest precipitation will be where the heat is subsequently greatest, and the rivers which flow from this part of the range, will have every opportunity of making their way eastward through the depressions.

Once at the foot of the Rockies, the rivers are on the great plain of Central Canada, where their pace gradually decreases until they become navigable without the slightest difficulty; and even where the pace is too fast for ordinary "up and down" navigation, light goods, such as grain, can be sent down on rafts, as is done also on the Damube. These rafts are naturally made of the timber which covers the foot hills of the Rockics, and which is very valuable in the middle of the plain, where there is neither wood nor coal ; and any 


\section{THE DOMINION OF CANADA}

heavy articles, such as agricultural machinery, which are needed " up " country, can usually bear the cost of transport by rail much more easily than food can.

Railways-The same physical conditions which make the rivers so useful for navigation, have also rendered railway construction easy and cheap; and the possession of excellent coal on the Atlantic and Pacific coasts, and at intervals along the southern latitudes of the country, has rendered the working of the railways equally easy and cheap. Of course, the Rockies have to be climbed; but, as the Canadian Pacific Railway crosses them (by the Wapta Pass) at 3,000 feet lower, and the Grand Trunk Pacific (by the Yellowhead Pass) at nearly 5,000 feet lower, than any U.S.A. line, the saving of steam power by the Canadian lines must be very great.

Besides the direct railway route through the whole country from east to west, and the wonderful waterway from the centre to the Atlantic coast, there are also routes northward and southward. One of the latter runs up the Red River valley into the States; the river itself is navigable into U.S.A. territory, and there are two lines of rail along its banks. The chief northward route is that via Hudson Bay and Strait.

The facilities for communication in all directions imply the absence of mountains, even along the U.S.A. border ; and, though this might lead to political trouble which would disturb commercial confidence, it gives free access to air and sun, and makes cultivation by machinery possible. Of course, cultivation of any kind is greatly helped or hindered by the level of the surface ; but cultivation on a large scale can be made profitable only by the use of machinery, especially in a newly settled country where labour is very scarce and dear, and machinery can be used best only on a surface like that of Central Canada.

It remains to be seen whether the soil and the climate are suited to the production of wheat as a special product. 


\section{CANADIAN WHEAT}

Wheat is a cultivated grass, the value of which lies almost entirely in the ear ; and this makes it top-heavy. Consequently, it requires to have its roots very firmly planted in the soil; and it is very sensitive to wind or rain, and especially to both combined. As a grass, it also requires moisture, light, and heat; and, though there are numerous varieties suited to different soils and different climates, to produce any variety in paying quantities sunshine and rich soil are necessities.

Now, the height of the Rockies guarantees that no wet wind can cross them without precipitating its burden of moisture ; and, even if it could, on the dead level of Central Canada there is no condensing medium to precipitate rain. Morcover, the precipitation of rain obviously frees heat; and, therefore, the S.W. Anti-Trade winds, having left their moisture on the sea-ward face of the mountains, pass on through the deep depressions across the range warm and dry. As they pass over the miles of land in summer, they naturally become warmer and drier ; and thus, as the " Chinook winds," they become of extreme value to the wheat-farmer of Central Canada.

Wind alone, however, will not ripen wheat; and the heat of the sum, of course, varies with the latitude. Paradoxical as it sounds, the farther wheat can grow from the Equator, the better it ripens. In the latitude of, e.g. the Qu'Appelle valley, the circumference of the Earth is so much less than at the Equator that the pace of the daily rotation is also much less; and, therefore, any given area of land passes from under the sun's rays nuch more slowly than at the Equator. Morcover, the farther north you go, the longer is the summer day; and the length of the day, and the slow passage of the sun over the wheat, cause the ripening to be very continuous and rapid, and yet very perfect. The same two factors also enormously facilitate harvesting. Norcover, the entire absence of both mountains 
and timber leaves free access to light and air from every side at the same time that it facilitates agriculture and communication.

Being a grass, wheat must have moisture; being top-heavy, it may be injured by rain. How then can it obtain the necessary moisture? Partly, from subterranean reservoirs, excavated by frost and filled with snow. The vast extent of land on every side makes the air very dry, and this causes intense cold in winter, the absence of vapour facilitating the radiation of heat from the soil at night. This intense cold covers the surface of the land in all directions with a network of cracks, sometimes several feet deep; and these cracks are subsequently filled with snow. From this source the roots of grain and grass can draw almost sufficient moisture to last them throughout the whole summer, especially if the land is well rolled; and, of course, the more it is rolled, the firmer are the roots of the plants in it, and the slower is the evaporation from the reservoirs.

The other source is from the light, but invaluable summer rains drawn inland off the Hudson Bay and Great Lakes by the continental area of low pressure; three-quarters of the total rainfall (under 20 inches in most parts of the prairie) comes in this way during the "growing" months, May-July.

Such retention of moisture, however, would be quite impossible in a loose soil ; but the formation of Central Canada is a stiff clay resting upon limestone, and the clay retains not only moisture, but also everything else which comes in contact with it. Consequently, upon the sub-soil of clay there is now a rich black alluvial loam, which is practically inexhaustible ; at all events, the same crop has been grown on the same land, e.g. at Kildonan, without any artificial manure for twenty to thirty years. The ricliness of the soil, as also its colour, is due to the accumulation through centuries of the droppings of birds and beasts, and the ashes of prairie fires. As the latter generally occur in Spring, the ficlds 
of young grain have to be protected from them by a few furrows of fallow.

The obstacles to the successful cultivation of wheat in great perfection, and on an enormous scale, have been locusts, summer frosts, and floods. The locusts have, as usual, disappeared before the plough ; but the frosts and the floods are the result of the more permanent causes.

The frosts are primarily due to the absence of mountains along the north of Canada, which allows the cold winds to blow down from the Arctic Ocean over the wheat-fields of the central plain; and they generally occur during the latter half of August, i.e. when the long summer has dried up every green thing on the face of the prairie. Then no moisture is left to be evaporated, and the slightest breeze from the north nips the wheat. The cause of the frosts being known, there is a choice of remedies. One is planting artificial grasses, shrubs, or even trees, all of which draw their moisture from the deeper layers of the soil, and therefore can resist long-continued heat much better than the natural grasses of the prairie can. Another is sowing early; but, as that necessitates ploughing in Autumn instead of waiting till the Spring, it cannot be done everywhere or in every case. A third is using hardier seed, e.g. Fife or North Russian. The most obvious device, however, is what is known as smudge-firing, i.e. burning damp straw along the north side of the wheat on a frosty night. Straw is of no value in these districts, and the climate is dry enough for it to be left permanently in heaps on the field without its rotting away; the frosty nights are very rare, and almost never come twice in the same summer ; the number of " hands " on a wheat farm is sufficient to make the work of watching for the frosts very easy during the two or three wecks during which they are to be dreaded; and, as a rule, the wind is so light that there is no danger of the smoke being blown too far. In any case, the wind would be quite harmless after passing the line of bonfires. 
The floods are due to several reasons. One is the great want of wood to check radiation at night ; and, of course, that want can be supplied by planting trees. Another is that ploughed land naturally presents a larger surface for evaporation than unploughed; but, as the area under the plough increases, the wider distribution of the rainfall will relieve the local pressure. The third is the absence of mountains along the south of Canada, which causes the cold winds from the north to meet the warm winds from the Gulf of Mexico just over the slight elevation which forms the International boundary, and from which the Mississippi and Red rivers flow.

In Central Canada, then, there is an enormous area of level, easily tilled land, with very rich soil, underground reservoirs of water, long summer days, intense frost to clean and pulverize the soil, and just enough rain; the price of land is extremely small, and there is a magnificent system of railways and waterways. Consequently, humanly speaking, merchants can rely on huge, perfect, and constant supplies of wheat from this part of the world.

\section{CANADIAN TIMBER}

Eastern Canada produces timber and, where the timber has been cleared, grass; and the Dominion owes much of her present prosperity to the lumberers who cleared the land, made roads, and bridged rivers. The suitability of Eastern Canada for timber and grass is owing to its position between three large areas of water - the Great Lakes, Hudson Bay, and the Atlanticwhich affects its climate, especially with regard to the amount of moisture. There is, however, practically no condensing medium for rain; so that most of the moisture is precipitated-by cold winds from the north -in the form of snow. This is not so true of Nova Scotia as of the other maritime provinces, and the 
facilities for export by canals and by sea have caused the Nova Scotia forests to be largely " cleared " for pasture. Indeed, the ease with which stock can reach Halifax from all parts of the province, gives the Nova Scotia farmers a great advantage over the farmers farther west. Even in the matter of timber, however, Nova Scotia is favoured-by the number of its canals, its command of sea carriage, and the enormous demand for firewood in the densely populated north-eastern States of the Union.

New Brunswick is the most entirely a lumber province, and much of the timber is grown along the Restigouche river. The province is very flat; and, though the air is too dry for the climate to be unhealthy, there is a vast amount of marsh. This is the home of the cedar; and its preference for swamps makes it very useful for boats, fences, and railway "sleepers." The commonest tree, however, is the black spruce, which is strong and light, and grows to an average height of sixty feet with an average breadth of two feet. The hemlock spruce, though less common, is more valuable, as its bark is very useful for tanning purposes. Indeed, the proximity of large hemlock forests to the north of Fredericton, and of pasture along the St. John river in the same district, has given that town a large leather industry. The most valuable of all the New Brunswick woods, however, are pine and maple. The former is soft, light, and free from knots; the latter compensates for its need of good soil by being extremely useful. Its sap gives a large amount of sugar during March; its beautiful timber is in great demand amongst cabinetmaliers; and the presence of sugar in it makes it superior to all other wood for fuel.

The cheapness of Canadian timber is due to two facts :it is cut in winter, when there is no other demand for labour; and it is transported in winter, when the snow can be beaten into excellent temporary roads. Obviously, too, these roads can be made as easily in unsettled parts of the country, where the supply of timber is largest and best, as in scttled parts, where the land is 
being rapidly cleared for pasture and agriculture. The "logs" are dragged to the banks of streams over the frozen snow, and left there for the Spring floods to carry down to the saw-mills. Half the capital of New Brunswick is invested in saw-mills at St. John.

Quebec Province produces hard timber as well as soft. The hard is grown on the comparatively " soft " rocks of the Notre Dame range, between which and the St. Lawrence there is excellent pasture ; and, in addition to the river, the main line of railway from Halifax to Quebec via Point Levis-the only route in winter-runs through the district. The soft timber, which is much the more valuable, is grown in the limestone valleys that intersect the " hard" rocks of the Laurentian range. Towards Ottawa the species are the valuable red and white pine, elsewhere spruce, cedar, maple, and birch. An immense trade in the latter is carried on down the Saguenay river to Tadousac.

The centre of the lumber trade in this province is the city of Quebec. There, as at Fredericton, the proximity of hemlock forests and of pasture has given rise to a leather industry-one of the most important on the North American continent

The centre of the whole lumber trade of the Dominion is Ottawa, which draws supplies of red and white pine both from its own province and from Quebec. It stands on the Ottawa river about ninety miles from its mouth, and it has canal as well as river communication with Montreal. The mills are at the Chaudière Falls, which are close to the city, and are kept going day and night while the river is open. The abundance of water guarantees protection from fire directly and indirectly, the latter by affording means of lighting the mills throughout by electricity at an extremely small cost. The same men who work in the mills, go up-country "log-cutting " when the river is frozen.

The manufacture of the timber also has its centre in Ontario, at Deseronto, where the Grand Trunk Railway 
skirts Quinte Bay. This position is admirably adapted for both collection and distribution by rail and by water. The chips provide fuel, or are combined with clay into terra-cotta ware, or are converted into charcoal.

Forests-almost untouched as yet-also cover the west, i.e. the wet, side of the Cascade Mountains in British Columbia. The principal trees are pine, cypress, and cedar; and, owing to the moderate temperature and its slight range, some of them grow to an enormous height without growing too fast to have a good grain. For instance, the Douglas fir, though it grows to a height of 300 feet almost perfectly straight and with very few knots, is tougher than some species of oak. It is, therefore, very useful for masts.

\section{CANAIIAN PASTURE}

The great export trade in cattle and clieese is maintained by the Maritime Provinces, Ontario, and the eastern slopes of the Rocky Mountains, especially those in Alberta.

The Maritime Provinces.-The eastern half of Nova Scotia has poor soil and a damp climate, and is specially well situated for export via Halifax; Prince Edward Island produces enormous crops of grass, partly owing to the valuable supplies of "mussel mud" manure found round the shores of the island; New Brunswick has dyked lands along the Bay of Fundy, which produce rich saltish grass, especially between St. John and Shepody.

Ontario has had such an uneventful history that its population is denser than that of any other province; the soil carries very heavy root crops and is magnificently watered ; the failures among agricultural farmers in the past, owing to gross stupidity in over-cropping the land with wheat, frightened the pcople a generation ago into pastoral farming; and the demand for cheese and butter in the British markets made them 
turn their attention to cattle. Four-fifths of all the Canadian cheese-and Canada is at the head of all cheeseexporting countries-comes from Ontario, though it is actually shipped at Montreal. Indeed, in I9I7 Ontario produced creamery butter to the value of about $£ 2,500,000$ and cheese to that of $£ 5,150,000$.

In Alberta the number of streams, the slope of the ground, and the climate are very favourable to cattle; and Calgary, which stands on the Canadian Pacific Railway, thus became the centre of a huge meat and dairy trade. In the Eastern Provinces the heavy snowfall necessitates the housing and artificial feeding of the cattle in winter, and the grass is largely "sown" (Timothy); but in Alberta the snowfall is very light, owing to the dryness of the air, and the grasses are all " natural," which do not produce quite as much milk as "sown" grasses do. Moreover, the dryness of the climate has the remarkable effect on two grasses"Buffalo" and "Bunch"-of converting them into hay while they still remain uncut. This hay is much more nourishing than ordinary cut hay; and, as the snow is never deep enough to cover it, the cattle can feed over the pastures in winter, thus obtaining exercise in the fresh air and requiring little or no house-feeding.

The result of all this was that from I880 to 1900 Alberta was the greatest ranching country in North America; but recently the relative importance of ranching as compared with agriculture has fallen rapidly, and inixed farming-combining dairy work with pig-raising -has become so important that in I9I7 no less than $23,000,000 \mathrm{lbs}$. of butter were made.

\section{CANADIAN FRUIT}

There is a large field for fruit-growing in many other parts of Canada, especially in Ontario and British Columbia; but Nova Scotia has already become the most famous country in the world for apples. 
The centre of the industry is Minas Basin, which is in the latitude of Bordeaux. That district combines all the essential conditions for successful apple-growing. Round the Basin lie some pine-clad hills which shelter the slopes beneath them; the North Mountains keep off storms from the Gulf of St. Lawrence; the seasons are ideally arranged-late spring, hot summer, and short autumn, the latter checking the flow of sap very shortly after the fruit is picked; the usual parasites are almost unknown; the dry climate has a favourable effect on the fruit both before and after picking; land is cheap ; the same trees will continue to bear fruit for at least fifty years on an average; markets are near; and connexion with them by rail and canal to Halifax and by steamer to New York is easy and cheap. There is a slight lack of labour, but women and children can do the picking and packing. Gravensteins and Golden Russets perhaps suit the climate best.

In British Columbia, especially round New Westminster, pears will probably be most successful. In Ontario apples, peaches, and grapes seem equally promising. The peaches and grapes do best in the semimarine climate of the Niagara peninsula, especially on the shale formation of Hamilton.

\section{CANADIAN COAL AND IRON}

There are three great coal areas-those of Nova Scotia, British Columbia, and the "Winnipeg Basin"; but at present coal-mining is practically confined to the neighbourhood of harbours and railways.

The Nova Scotla coal is found along the north shore of the Peninsula and on Cape Breton Island. The Island field is round Sydney, near the narrow entrance to the Bras d'Or Lake; and its proximity to Louisberg, the most easterly harbour in North America, gives it special advantages. It raises steam very quickly, and makes cxcellent gas. The Peninsula field lies along 
Northumberland Strait between Pictou and Springhill, in the narrow plain which divides the Cobequid Mountains from the sea, and across which the Inter-colonial Railway runs. It contains excellent coking coal in very thick seams; and the presence of the finest iron ore and pure limestone in the same district has given rise to important iron industries at New Glasgow, Truro, and Londonderry.

The British Columbian coal occupies a very similar position, and is perhaps more important. It lies-partly inland along the Canadian Pacific Railway near Kamloops, where, however, there is no water communication in any direction,- - partly along the eastern, i.e. the landward, shore of Vancouver Island, at Nanaimo and Comox -partly Ioo miles farther north, in the Queen Charlotte Islands. The facilities for shipping at Nanaimo and Comox are magnificent; the island of Texada, which lies off Comox, is simply a mountain of magnetic iron ore; and the coal itself is better than any other bituminous coal found on the Pacific Coast of the Americas. The Queen Charlotte Islands contain the only known deposits of anthracite-except a few seams in Vancouver Island-along the whole length of the same coast-line.

The Coal in the Central Basin is generally of poor quality, but of enormous extent. The northern area stretches along both sides of the Mackenzie River, from its mouth to Fort Norman; the central area stretches for at least 400 miles north and 400 miles south of the Peace River, from its mouth up to the Rocky Mountains ; and the southern area stretches from the Turtle Mountains along the South Saskatchewan River also up to the Rocky Mountains. The latter is at present much the most important of the three, as the Canadian Pacific Railway runs through the district. Moreover, some of the coal, especially between Banff and Calgary, is anthracite; and the importance of deposits of anthracite, within two days' journey of the Naval Station of Esquimalt on the great Imperial Route of the Canadian 
Pacific Railway can scarcely be over-estimated. Most of the inferior coal goes, from Dunmore and Lethbridge, to the mining centres of Montana, e.g. Helena and Butte City. Edmonton is the chief lignite centre.

\section{CANADIAN PRECIOUS METALS}

Gold is worked in Nova Scotia, and both gold and silver are worked in Ontario and British Columbia. The gold is found along the Fraser and the Columbia Rivers, specially in the Cariboo section of the Fraser basin; the silver is found farther down the Fraser, at Hope, where the river is navigable, and along the shore of Lake Kootenay. Abundance of water and of timber has given the British Columbia miners an immense advantage over their Australian rivals; but the cost of importing machinery is enormous. There is considerable difficulty in carrying on the work during the winter, and the silver mines are not nearly so rich as those of Cobalt (Ont.). There are also large deposits of gold in the Klondyke district of Yukon. Good roads have been made, and there is both rail and river communication with the Pacific coast.

Ontario contains the richest deposits both of copper and of nickel in the world. The former are in Algoma, on the navigable waters of Lake Huron, and along a branch of the Canadian Pacific Railway; and the copper is almost absolutely pure. The deposits of nickel are round Sudbury, where the same branch joins the main line of the Canadian Pacific Railway; and the impenetrability of nickel-steel armour, the superior toughness and elasticity of nickcl-stcel over the best mild steel, and the freedom of nickel-plated hulls from corrosion and fouling, make the deposits of immense importance to a naval power like Great Britain.

Amongst other important mineral products of Canada are Gypsum and Apatite, two compounds of lime, which are very useful as manure, especially for wheat. The 
Gypsum is exported chiefly from Windsor (Nova Scotia), though there are rich deposits along the Tobique River (New Brunswick) and between Niagara and Lake Huron. The Apatite is exported chiefly from Hull, though the deposits run on westward into Ontario, in the direction of Perth and Kingston.

\section{CANADIAN FURS}

The Fur trade is entirely in the hands of the Hudson Bay Company, except as far as sealskin is concerned; and the most valuable furs-those of the beaver, fox, mink, skunk, and musquash-come from the least valuable land-the rough marshes to the east of the Mackenzie River. They are collected by "Indian" hunters, who are paid in ammunition, tobacco, cloth, etc. The headquarters of the Company which used to be at Fort York, have been transferred to Winnipeg, and most of the export goes up the Red River valley into the United States; but the trade will now probably make use of the new railway facilities that are being provided to Hudson Bay, i.e. return to its old route.

\section{NEWFOUNDLAND}

Newfoundland itself is not much larger than Ireland, but the colony includes an area of Labrador about equal to the United Kingdom.

The Coast-The chief characteristic of both the island and the mainland portions is the extent of broken islandfringed coast, which provides a series of excellent harbours, the capital of St. John's being particularly good. By the Treaty of Utrecht (I 7 I3) the French possess the islands of Miquelon and St. Pièrre, and till lately claimed exclusive fishing rights along the west coast, from $\mathrm{C}$. Ray to C. St. John. This was a great injustice to the colony, as it is essentially a fishing community,-thanks mainly to the action of ocean currents in piling up banks 
near enough to the surface of the water-over a vast submarine plateau-to be covered with the seaweed in which fish can find their food and lay their eggs.

Fishing-One-third of the population is engaged in fishing, the cod fishing-off the Great Banks-being more important than all the other industries of the colony put together. Next in importance are the seal and herring fisheries, the seal fishery (off Labrador) being conducted for oil and skins, not furs.

Minerals-The constant fogs and the rough hilly surface make agriculture quite insignificant, but the mineral wealth is considerable. There is good coal in the Grand Lake district and round St. George's Bay ; large beds of iron are being worked on Bell Island, in Conception Bay; and there is excellent copper round Placentia Bay, which is conveniently near to the cable terminus of Hearts-Content Harbour. There is a railway right through the island, connected at Port au Basques by a steamer with C. Breton Island ; and there will probably be a considerable development of " coldstorage" trade with England.

\section{BRITISH CENTRAL AMERICA}

British Central America is a very "rough" title for three areas ; (I) the mainland of British Honduras and British Guina, (2) the British possessions in the West Indies, and (3) the Bermudas.

The Bermudas are a group of coral islands, which owe their existence-so far outside the Tropics-to the Gulf Stream, as the coral formation of Japan is due to the Kuro-Siwo. The Gulf Stream also gives them a wonderful climate, which makes Hamilton and St. George favourite winter resorts for Americans, and which makes the islands generally a market-garden for early vegetables (onions, potatoes, tomatoes, etc.) for NewYork.

British Honduras and British Guiana consist of low, 
swampy plains, backed by forest-clad mountains. The lowlands grow quantities of sugar, especially along the Demerara, and the forests include logwood and mahogany. The chief mahogany centre is Belsize, and the chief sugar centre is Georgetown.

The West Indian possessions may be divided into the Bahamas-low, unfertile coral islands, outside the Tropics, and the West Indies proper-fertile volcanic islands inside the Tropics; and the latter group may be sub-divided into (I) Jamaica, and (2) the Lesser Antilles or Windward Islands. The British Government divides the Lesser Antilles into "Windward" (St. Lucia to Trinidad) and "Leeward" (the Virgins to Dominica); but the name "Leeward" is absurd for islands which are full in the teeth of the trade-winds. The chief products are coffee, cacao, sugar and rum. The coffee comes specially from the Blue Mountains of Jamaica, via Kingston and Port Royal ; the cacao comes specially from Trinidad, via Port of Spain; and the sugar specially from Jamaica and Barbados (Cf. "Jamaica rum "). Fruit is also widely grown, e.g. bananas and pine-apples, specially in the Bahamas, cf. the limes of Montserrat; and cotton is becoming important again, e.g. in St. Vincent, Barbados, and Grenada.

\section{AUSTRALIA}

\section{SURROUNDINGS}

Australia is an island; but it is so large that it must be regarded commercially as a continent. It occupies an area twenty-five times that of the United Kingdom; and, in relation to the rest of the empire, it ranks next to Canada in size.

Coasts-Australia lies between the Indian and the Pacific Oceans; and Sydney is in about the latitude of Cape Town or Buenos Ayres, which corresponds to that of the Bermudas or Cyprus north of the Equator. Warm currents wash its north, east, and south coasts; on the 
west there is a cold current, off which evaporation is small and slow. The coast-line is very little broken; and the indentations which do exist, the Gulf of Carpentaria and the Great Australian Bight, have little effect on the "solidarity" of the whole continent.

This is most true of the south coast. In the western half there is absolutely only one harbour-Albany, on King George's Sound, which is a very important harbour of call for vessels making Australia from the west. The eastern half of this coast is much more broken -by Spencer Gulf, the Gulf of St. Vincent, and Port Phillip; but the abrupt cliffs, the heavy swell, and sunken islands make navigation by no means safe. Lighting and buoying are, however, very carefully carried out. On Spencer Gulf there are two very important harbours, Port Augusta and Port Pirie. The latter, which ships large quantities of wheat, has the regular through-trade to the Broken Hill and Silverton mines. Port Augusta is the outlet of a large pastoral and mining area, a rising wheat port, and the terminus of the Great Northern Railway, which is the southern half of the projected Trans-continental line. Port Adelaide has a fine natural harbour under the lee of Mount Lofty; vessels of any size can enter its outer port, Semaphore, at any time and $i$ in any weather.

Melbourne-The Victorian portion of this coast, however, contains the most important harbour, that of Port Phillip, which has become one of the most important harbours in the Southern Hemisphere. The "Port" is an enormous bay, 40 miles long and 40 miles wide, and contains two smaller bays, Corio Bay and Hobson's Bay, on the latter of which Melbourne stands. At Port Melbourne there is berth accommodation for a whole fleet; and vessels not drawing more than 8 feet can go up the Yarra actually into the very heart of the city. The whole normal trade of Victoria in gold, wool, and wheat passes through Port Phillip; and, if there was only coal in the neighbourhood, the harbour would be 
one of the most important in the world. On the other hand, now that the Commonwealth has given up the absurd custom of having different railway gauges, and is instituting a complete Inter-colonial railway system, Wentworth, a small town at the confluence of the Darling and the Murray, will probably be made the centre of the system; and this may have a very bad effect on the trade of Melbourne.

The West Coast, from Cape Leeuwin to Cape Leveque, is low and monotonous, and largely protected by a line of coral reefs; but the shallowness of the water, the direction of the prevailing winds and currents, and the strength of the latter, make navigation difficult and dangerous. The northern half is also subject to violent hurricanes in summer (February), and is very unhealthy. Shark Bay is the only important inlet, and has thus become the centre of the pearl fishery. In the southern part of the coast Freemantle has been made into a fairly good harbour to accommodate the trade up to Perth, the capital of Western Australia; and it has a large salt industry.

The North Coast, from Cape Leveque to Cape York, contains a series of fine bays. The best is Port Darwin, the harbour of Palmerston. It is one of the finest of all the Australasian harbours, being accessible by the largest vessels in any state of tide or weather, possessing natural sites for a dry dock, fortifications, and lighthouses, and having been provided with excellent harbour works. Palmerston itself is quite a small town, and not healthy ; but as the junction of the Overland Telegraph with the Eastern Cable, and the destined northern terminus of the Transcontinental Railway, it is very important.

The East Coast is the best of all. It is protected for I,200 miles by the Great Barrier Reef ; it has a series of good harbours, that of Sydney being magnificent; it is well provided with excellent coal; and it has the richest resources behind it, and the best means of reaching them. For instance, Brisbane, Rockhampton, and 
Townsville have lines of rail running directly inland for several hundred miles. The Brisbane line commands the coal and wool trade of South Queensland; the Rockhampton line commands the gold and cattle trade of Central Queensland; the Townsville line commands the gold trade of the famous Charters Towers and Ravenswood mines. Cairns and Cooktown have slightly inferior harbours, and are backed by country too rough for easy railway construction; but the former commands the important tin trade of Herberton, and exports annually between I5,000,000 and I0,000,000 bananas. Cooktown has also a large tin trade, as well as a trade in gold, rice, sugar, and bêche-de-mer; but its importance is due to its position. It is the most northerly port on the east coast, and it is just opposite the best channel through the Great Barrier Reef. Cf. Townsville.

Sydney-On the New South Wales portion of this east coast there are several excellent natural harbours, c.g. Botany Bay, Broken Bay, and Port Stephens; but they have been rendered comparatively unimportant by the unique excellence of Port Jackson. The latter is an expanse of deep water about I2 miles long and from I to 2 miles broad; the entrance is protected by rocky heights, which are crowned by batteries 300 feet above the sea-level; Sydney itself occupies a succession of small promontories forming three sides of a square, with a natural wharf of freestone on each side; the largest vessels in the world can lie close inshore along these wharves; splendid coal-fields lie to the north and the south, at Newcastle and Illawarra ; and the harbour has a splendid railway service, being on the main line from Melbourne to Brisbane, and having direct communication inland.

\section{SURFACE}

Australia is an enormous plateau, with a margin of low coast-land on every side except the south. The 
outer edge of the plateau is formed in most places by a range of low 'mountains,' which often rise abruptly from the coastland only to break off abruptly on to the plateau. This has a most pernicious effect on the rainfall inland. Moreover, the plateau sinks as it recedes from the coast; and, though this natural sinking favours the accumulation of water underground in the limestone of which the country is largely composed, the dryness of the soil and the extreme heat give surface water a very slight chance of sinking at all. In the west, where rain depends on occasional winds blowing over a cold current, thousands of square miles are, and must ever be, barren desert.

The highest part of the 'mountain' ridge is in the south-east, where Mount Kosciusko and Mount Townsend rise to a height of about 7,000 feet. This is much below the snow-line in that latitude; and consequently, though the Murray and Murrumbidgee rivers, which flow from this centre, are extremely important for irrigation purposes, for navigation they are comparatively useless.

The coast districts of the continent are naturally in a very different position. Even in the west sufficient moisture is brought to the Darling Range to provide the strip of land between the range and the sea with sufficient rain for pasture, if not for agriculture; and in the north an even unhealthy abundance of rain is brought landward off the tropical Arafura Sea. The east coast is exceptionally situated. It is backed by the Great Dividing Range, and faces the S.E. Trade Winds, which blow landwards over hundreds of miles of warm sea. Moreover, the 'mountains '-at least, in Queensland, i.e. where the heat is greatest-are very near the sea; and this compensates partly for their want of height. This coast is, therefore, well supplied with rain and rivers; but many of the latter are simply temporary surface torrents, all are subject to sudden floods, and all are short. Thus they are of no use whatever for internal communication; and the floods not only make naviga- 
tion precarious or even impossible, but also bring down so much débris as to do often more harm than good to the low-lying agricultural lands.

\section{AUSTRALIAN PASTURE}

With such a deficiency of rivers and rain inland, it is obvious that agriculture must be extremely limited. Pasture, however, especially for sheep, is very much less dependent on the rainfall; and there is sufficient moisture in the interior of Australia to make wool the great product of the country.

New South Wales is far ahead of the other Australasian States, as a wool-producing country; and, in this connexion, it is worthy of notice that it practically monopolizes the entire continental river system. Yet even in New South Wales there are vast plains between the rivers, where the rainfall is not nearly sufficient even for grass. In these places there is a natural growth of saltbush, a semi-desert plant which is said to excel all other sheep-food in its wholesome and nourishing qualities; and, so long as the surface is not too sandy, the absence of rain is a positive advantage. The only necessary precaution is to stock the land very lightly for fear of a drought. Even with light stocking, however, pasture sometimes becomes so scarce during a severe drought that as many as 2,500 sheep have been killed and burnt on a single " run," their skins alone being worth keeping. Nevertheless, the importance of the wool trade has led to a great development of railway construction, e.g. the extension of the Western Railway as far as Bourke, and the excellence of the Southern system in the Riverina.

The same is true of Queensland. For instance, the pasture of the Richmond and the Darling Downs is so good that the Northern Railway was soon extended from Charters Towers to Hughenden and Winton, and the Southern and Western from Toowoomba to Charleville. The general character of Queensland, however, is more 
tropical than that of New South Wales; and wherever tropical rain falls, the climate is much more suited to cattle than to sheep. Consequently, the Central Railway brings frozen beef, not wool or mutton, to Rockhampton. Still, Queensland sheep-farmers have certain advantages in several parts. One of these is the possession of valuable native grasses, e.g. the Mitchell grass, which can withstand long droughts and recover very quickly after a very small rainfall. Another is that, even on the Pacific, i.e. the damp side of the Dividing Range, there is some volcanic formation, e.g. on the Rosella Plains in North Kennedy, which affords very healthy pasturage for sheep. A third is that, owing to the lower latitude and the lower elevation of the 'mountains,' more rain is carried inland in Queensland than in New South Wales. Want of water is, however, severely felt ; and dams and tanks have done comparatively little to guarantee squatters against terrible losses even in a single dry season. The difficulty is being solved by sinking artesian wells into the limestone formation. For instance, the continuous yield of water in Queensland is estimated at well over 400,000,000 gallons a day-from over I, Ioo wells.

The best wool comes from Victoria, where the quality of the grass and the dryness of the air, in the higher latitude, produce a wool that is almost unsurpassed for softness, lustre, and length of staple. The volcanic formation of the Ballarat district is specially beneficial, and in connexion with it a rather famous Tweed industry has sprung up at Geelong, where also the sheep skins are tanned with wattle bark brought from the north of the colony. But the comparative smallness of the colony, the excellence of the railway facilities, e.g. round such towns as Castlemaine and Sandhurst, and the bonuses given by Government on butter sold in London and Glasgow, have led to a very large development of the dairy industry. Indeed, nearly one-third of all the butter imported into London during the winter is 
Australian. The factories, of which Benalla possesses no less than eight, are on co-operative principles, and bonuses are paid after the sale of the produce.

Pasture is also of great importance to South Australia, but the intense dryness, the scorching winds from the north, and the consequent looseness of the soil-not to mention plagues of rabbits and wild dogs-make sheeprearing very precarious, and spoil the wool. There is, however, sufficient rain near the south coast, especially in the neighbourhood of Adelaide, to support an export trade in butter and cheese, most of which goes to the other Australian colonies. It is rather curious that Port Pirie, the great wheat port, should be also the centre of the wool trade. Port Augusta, though not much farther north, has only 9 inches of rain in the year.

\section{AUSTRALIAN AGRICULTURE}

The Agriculture of Australia is naturally confined to the edge of the tableland and the coastal strips, where the rainfall is much greater than elsewhere and reliable, and where machinery can be imported cheaply. The tableland districts are, of course, the cooler and the drier of the two; and, therefore, they produce plants like wheat and the vine, while the coast strip produces sugar, maize, and bananas.

Wheat is grown in all the states, but with very different results. Victoria usually produces the most, and South Australia comes third; but in I9I5-I6 New South Wales produced over 66,725,000 bushels against Victoria's 58,500,000, and in I9I6-I7 South Australia produced nearly $45,750,000$ against the New South Wales $36,585,000$. In I9I9-20 South Australia, with ncarly I $4,95^{\circ}, 000$, was even above Victoria. The other States are relatively unimportant, but Queensland is the only one that lias to import wheat, while all the rest, with the exccption of Tasmania, are usually able to export considerable quantities, 
Vine-There has been a great development in vineculture. The vine has a long root, which enables it to resist drought; the area of land required is small, and therefore the demand for labour is small ; the industry demands little capital, while the need of careful and constant attention is most likely to be supplied by men possessing little capital ; the stony slopes of the volcanic and limestone Downs, where the climate is perfect for the vine, produce wines of very fine quality. For instance, many gallons of quite good wine are produced annually even in Queensland, mainly from vineyards between Roma and Brisbane. Naturally, this industry has received great encouragement in the densely populated mining districts of Victoria; and, as the volcanic formation is equally favourable to the vine and to gold-prospecting, the important mining centres of Ararat and Stawell are also the wine centres. In the drier air of the Murray district, e.g. at Shepparton, Nagambie, and Rutherglen, the crop of the many thousand acres under the vine is converted almost entirely into raisins. Indeed, the success of the industry encouraged the farmers of South Australia to plant vines on the plains and hills round Adelaide. The plain vines produce "Spanish" wines, while the hill vines produce claret. The climate is admirably adapted for curing raisins; and a fair yield of grapes per acre is at least four times as valuable as a good yield of wheat. South Australia produced over 5,000,000 gallons of wine in I9I8.

The Sugar, Maize, and Bananas are largely confined to Queensland and the Northern Territory of South Australia, as all three require tropical rains. Sugar, which grows best on a fertile marly soil exposed to intermittent sea-breezes, naturally prefers that part of the Queensland coast strip which faces the S.E. Trade Winds, especially the land between Mourilyan and Cairns and that between Townsville and Mackay. The great difficulty is the "Labour Question." In the 
north, where the climate is most suited to the sugar, it is least suited to Europeans, though it pays to employ White labour; in the south, where the climate is fairly well suited to Europeans, the cane fares so badly that there has been a great decrease in the area under sugar, especially from Maryborough to Brisbane. At Bundaberg, however, which is just north of Maryborough, the industry is well maintained, chiefly owing to the large yield per acre (more than 20 tons).

Maize grows all along the Queensland coast, especially on the low land between Brisbane and Rockhampton, and along the northern coast of the continent. The advantages of growing maize are that -it provides food for both man and beast; it grows very rapidly, two crops being often grown on the same land in the same year; and this does no harm, as the crop takes very little out of the land, its needs being almost limited to heat and moisture. Moreover, the amount of labour required is very small. Indeed, on "scrub" lands it is only necessary to burn off the scrub and then to drop the seed into the ash " top-dressing." The success of the plant depends on the rainfall, the heaviest crops being grown round Geraldton; but the largest area under maize is on a sheltered plain west of Brisbane, where the smaller rainfall is compensated by the greater freedom from floods.

The Banana grows under much the same conditions as maize, and Queensland produces millions of dozens every year. The Cairns district alone produces between fifteen and sixteen millions; and the only obstacle to the industry is the necessity for regular access to large markets, e.g. London and Glasgow.

\section{AUSTRALIAN MINERALS}

Coal exists in abundance on the east coast, and is, in most cases, of a very good quality. There are four chief centres-two in New South Wales and two in Queens- 
land. The New South Wales collieries lie along two rivers, the Hunter and the Nepean; and there is a probability of good coal being found under the sandstone in the Hawkesbury valley. The most important of the four fields is that along the Hunter, and it has received the characteristic name of "Newcastle." The town of Newcastle itself stands at the mouth of the river, on the edge of a sudden break in the level of the country; and the coal was thus laid bare by the heary rains brought by the S.E. Trade Winds. Exactly the same thing happened between Bulli and Illawarra, where some of the seams are 600 feet above the sea. At both Bulli and Wollongong harbour works have been carefully constructed, and the facilities for shipping the coal are very complete. Sydney has thus an abundant supply of good, easily worked coal to the north and south and inland at Lithgow. In fact, the New South Wales coal-fields, both in extent and in quality, are far more important than those of any other State in the Commonwealth.

The Queensland fields are almost equally well situated. The more important of the two is at Ipswich-also on the edge of a sudden break in the surface level-which is about 24 miles west of Brisbane. The other occupies a similar position in the Burrum district, a few miles from the important coast town of Maryborough. There are several less important coal-fields; one of them is the Bowen-river field, tapped from Rockhampton, e.g. at Claremont; south of this there is the good, but undeveloped, Dawson-river field.

Iron deposits are found in New South Wales, Queensland, South Australia, West Australia, and Tasmania ; but it is only in New South Wales, especially round Lithgow, that they have as yet been worked to any great extent.

Gold is found in many parts of New South Wales, e.g. at Wyalong and Mount Boppy (near Cobar); but the great gold colonies are Queensland, Victoria, and 
Western Australia, the latter ranking second in the world. In I 890 it produced only some $20,000 \mathrm{oz}$. of gold, while in I9I4 it produced about I,550,000 oz. The chief centres are East Coolgardie, Mount Margaret, and the Murchison river; Mount Margaret is connected with Freemantle by some 600 miles of " desert " railway, and fresh water is pumped from the Swan river as far as Kalgoorlie (nearly 400 miles), on the Trans-continental Railway from Freemantle to Port Augusta.

The mineral wealth of Victoria is almost entirely in gold, the western half of the colony consisting of an area of volcanic disturbance in the middle of very old rock. The gravel beds into which the gold-bearing rocks had weathered, are now exhausted, and there is need for science, machinery, and capital to develop the quartz mines; but the latter are much the more reliable. By far the most productive mines are round Bendigo, Ballarat, and Maryborough. The fact that some of the richest mines were discovered-naturally-in deep depressions across the Dividing Range, and that the heavy mineral traffic very soon made bush roads impassable and macadamized roads terribly expensive, gave a great impetus to railway extension in Victoria. The lines radiate from Melbourne; and the Western, which serves the Ballarat, Ararat, and Stawell goldfields, runs also to join the South Australian system at Serviceton.

Queensland has three important gold-fields. The richest is in the north, and occupies practically the entire territory north of a line from Mackay to the Flinders river ; but its centres are Charters Towers and Ravenswood, both of which are on the Northern Railway in the valley of the Burdekin river. The work even at these two centres-and still more on the "Gulf "watershed, e.g. at Palmerville-lias been much hindered by the intractable character of the ores. The Mount Morgan mines, which are served by the Central Railway from Rockhampton, yicld unusually pure gold; and there, 
too, as in the Southern fields round Gympie, copper is found as well as gold. Copper is also found in considerable quantities at Cloncurry.

Copper is, however, the characteristic metal of South Australia,-as gold is of Victoria, tin of Queensland and silver of New South Wales,-though the largest output recently has come from Cloncurry (Queensland) and Mount Lyell (Tasmania). The chief South Australian centres are at Wallaroo and Moonta. Owing to the absence of coal much of the metal is sent to Newcastle, New South Wales; but there are large smelting works at Wallaroo, the coal for which comes from Newcastle. As it takes probably four tons of coal to smelt one ton of copper, it is evidently advisable to send the ore to the fuel, not the fuel to the ore; but the ships which take the ore, can bring back fuel. New South Wales has also copper of its own, e.g. at Cobar.

The silver of New South Wales is also exported through South Australia, as the Broken Hill and Silverton mines are nearer to Port Pirie than to any other sea-port. These mines, too, were discovered on the edge of a sudden break in the level of the surface. The Broken Hill mine was one of the most valuable silver mines in the world; but its chief value now is as a producer of zinc and lead. ${ }^{1}$

Tin is the characteristic metal of the Malay peninsula, and exists in the continuation of that formation as far as Tasmania. The deposits extend along the Queensland heights from Chillagoe through Herberton to Warwick; they appear in the north of New South Wales at Tingha and Inverell; and they form the great wealth of Tasmania. The richest Tasmanian deposits are at Mt. Bischoff, Mt. Zeehan, and Mt. Lyell; and the "Brave West Winds" bring sufficient moisture to work the machinery by water-power winter and summer alike. The smelting is done at Launceston, which draws its supplies of coal from the collieries along the Lake and

${ }^{1}$ In $1889 £ 100$ shares were worth $£ 2,500,000$ ! 
the South Esk rivers. Longford is the centre of the Lake valley field, and Fingal that of the South Esk field.

\section{INDIA}

\section{SURROUNDINGS}

India contains a great variety of geological formation and of climate; but it may be roughly divided into two parts. The northern area is a low oblong plain, largely shut in by mountains; the southern area is an elevated triangular tableland, largely shut in by sea. The whole has a vast extent of alluvial soil, abundance of heat, and generally a sufficiency of water. Indeed, the extent of alluvial formation is responsible for the practical absence of minerals ${ }^{1}$ in many parts of the country.

The position of India is half-way between an enormous area of land and an almost equally enormous area of sea. The latter is entirely within the Tropics ; much of it is traversed by warm currents; and the Arabian Sea for Ioo miles off the windward coast of the country very rarely exceeds roo fathoms in depth. In June, i.e. summer north of the Equator, the terrific heat over Southern Asia draws the ordinary S.E. Trade Windsdeflected by the earth's rotation into S.W. windstowards India; and thus these winds bring an immense burden of moisture to be precipitated in India, especially to the S.W. and the N.E.

The coast along this extent of sea is not very accessible. For instance, much of the coast round the Bay of Bengal is simply swamp; and Bombay is the only really good harbour in the whole country. Elsewhere the regularity of the coast, the presence of sand-banks, and the strength of the occan and river currents, make the harbours difficult and dangerous. At the same time, several of these harbours, e.g. Calcutta, Karachi, and Madras, are extremely useful.

${ }^{1}$ The production of coal in Bengal and of gold in Mysore is ncreasing. 
Bombay is an island harbour opposite the southern entrance to the Red Sea, i.e. the Suez Canal. It is the only really safe, large, and accessible harbour in India. It has, however, two drawbacks-one is its distance from coal, all its supplies of which have to be imported by sea or rail; the other is its comparative inaccessibility from the land side. Since the construction of railways across the Western Ghats, however, these natural drawbacks have become of no importance-as long as the British Navy is supreme on the high seas. Moreover, the opening of the Suez Canal has naturally given Bombay a great advantage over all other Indian ports except Karachi ; and the trade of the latter is entirely confined to the Indus basin. Bombay is the outlet for all the trade of the rest of Western India, as well as for that of the Deccan and the Central Provinces. Its chief articles of export are cotton, yarn, grain, and oil-seeds.

Karachi is the great wheat port of the Punjab, and also exports the products of the Western Himalayan region. It is sufficiently far to the west of the Indus estuary to be safe from the constant currents and the periodical floods of the river; and the level character of the land right up into the Punjab has rendered the construction and the working of railways easy and cheap.

Calcutta stands on the Hugli, i.e. the most westerly of the fourteen channels through the Ganges Delta ; and, as its elevation above the river is very little, there is considerable danger from floods. During spring tides though the city is nearly Ioo miles from the sea, a "bore" travels up the river at the rate of 18 miles an hour; and during the summer rains the force of the river current is terrific. Indeed, a series of ports, of which Dacca alone remains, stood on different channels of the Delta before the rise of Calcutta; and all were ruined by the caprices of the river. Even now Calcutta is one of the most dangerous and expensive harbours in the world. Still, the fact that it is the commercial capital of British India and the outlet for the gigantic 
agricultural wealth of the Bengal alluvial plain, makes it a place of unique importance. Moreover, the chief Indian coal mines are at and near Raniganj, a smaller town in the Damodar valley; and there is a double railway system to serve the two sides of the river system, connexion across the river being provided by a railway bridge at the town of Hugli. The great exports from Calcutta are coal, jute, tea, and manganese.

Madras stands on a surf-beaten coast without either a navigable river or a necessary shelter; and, though it has a fairly large trade, it is in no sense a natural harbour.

The land boundaries of India offer insurmountable obstacles to invasion and commerce except in the northwest. Along the north the stupendous range of the Himalaya Mountains runs for I,500 miles, with an average height of 17,000 feet and an average width of I50 miles. This huge range, in which at least roo peaks are about or above 4 miles high, is covered with enormous glaciers. These not only make the range even less practicable, but also supply the water for the magnificent rivers of Northern India, on which the very existence of Indian commerce depends. The three great rivers are the Brahmaputra, the Ganges, and the Indus ; and they provide the soil, the manure, the moisture, the drains, and the carriage for the valuable agricultural wealth of the Indo-Gangetic plain.

The north-east frontier is protected by spurs from the Himalayas and by a dense jungle growth ; the northwest is accessible to invasion through two or three deep defiles across the Sulaiman Mountains, especially the Khaibar and the Bolan Passes. All the great land invasions of India have been actually made via the Khaibar Pass. Of course, the same defile which lets invasion in, will let commerce out.

\section{SURFACE}

The Hindustan part of the Indo-Gangetic basin is one enormous plain-shut in by mountains on the north, the 
west, and the east, those on the north being of gigantic size; on the south the two river systems break out into the Arabian Sea and the Bay of Bengal respectively, and the edge of a high plateau runs across the country between the two estuaries. The low level of the plain offers every facility for communication by rail, road, and canal, as well as for irrigation and its dependent agriculture; and the height from which, and the rapidity with which the rivers fall, cause an immense amount of alluvium to be carried down by them on to the plains beneath. This is in some ways a drawback; for instance, the Indus becomes so choked with alluvium that it is useless for navigation except for quite small vessels. The latter, however, can reach Attock, which is 900 miles from the sea; and the value of the Indus and its four great tributaries for irrigation has made the Punjab, or Land of the Five Rivers, one of the wheat granaries of the world. The Ganges, on the other hand, unlike the Indus and the Brahmaputra, rises on the southern slope of the Himalayas, and is navigable for $I, 200$ out of its total length of $I, 500$ miles.

Another evil arising from the low level of this plain is, that the western half of it contains the Thar or "Great Indian Desert." Rain is brought to the country by the S.W. Monsoons, which naturally deposit their burden towards the N.E.; and this fact, coupled with the absence of a condensing medium, causes winds which subsequently deposit literally yards of rain on the Himalayas, to pass over Sind without a single shower. In the north-east corner, of course, the contrary happens, as much as 25 yards of rain falling there in one year. Indeed, Cherra-Punji is one of the wettest places on the face of the globe with an average fall of I3 yards; and the excessive rainfall makes the climate of all Assam so even that the growth of vegetation is most luxuriant.

The low"elevation and the excessive moisture make the whole of the Ganges basin distinctly unhealthy; and, though the moisture is absent in the Indus basin, 
the height of the Himalayas is so great that the heat is not tempered by cool winds from the north even in winter. At the same time, the fertility of the soil has encouraged a very dense population; and motives of economy, the climate, and religious prejudices cause the vast majority of the people to live largely on vegetable food. Naturally, too, in such a climate the demand for food and clothing is enormously greater in proportion to the demand for other things than in a temperate country like the United Kingdom.

The whole of the Indo-Gangetic basin may be divided into five areas-dry hills and dry plains in the N.W., damp hills and damp plains in the N.E., and a medium climate with a medium elevation along the water-parting which separates the plain of the Indus from the plain of the Ganges, and on which the political capital of Delhi stands.

The peninsula of the Decean is a triangular plateau, shut in on every side by 'mountains '- the Vindhyas on the north and the Ghats on the west and the east. The Western Ghats, are high, steep, continuous, and very near the sea; and, therefore, they act as a superb condensing medium to the S.W. Monsoons. Indeed, so complete is the precipitation that the interior of the Deccan often suffers from drought; and dams and storage tanks are of supreme importance. The Eastern Ghats are too low and discontinuous to act as a good condensing medium; and the supply of moisture brought off the Bay of Bengal by the "continental " N.E. Trade Winds is very small. The rainfall of the Western Ghats is sufficient to send a number of fine rivers-e.g. the Godavari, Kistna, and Cauvery-across the Peninsula into the Bay of Bengal ; but, though they are invaluable for irrigation, the country is too rough for them to be navigable. Moreover, as the Western Ghats are below the snow-line in that latitude, the depth of the rivers is rather variable. Unfortunately, too, the fact that they flood heavily when the new supplies of rain arrive on 
the S.W. Monsoon, causes them to plough deep valleys for themselves; and this renders irrigation by gravitation almost impossible except along the coast. In the hard rock wells are, of course, useless.

The Vindhyan Ridge is a double one, the southern line of heights being known as the Satpura ridge. The Narbada river runs between the two in a direction which allows the S.W. winds to penetrate far inland; and the same is true of the Tapti, which flows along the southern base of the Saptura ridge. Access from Hindustan to the Deccan is by a depression across the Satpuras just south of Khandwa, and this is the route followed by the Great Indian Peninsula Railway. Khandwa is the junction for Allahabad, Benares, etc., eastward, and for Delhi, Lahore, etc., westward. The direct routc from Bombay to Calcutta via Nagpur, Raipur, and the Damodar valley coal-field runs along the south of the Satpuras.

The two Ghat ranges meet in the Nilgiri Hills, which are nearly 9,000 feet high, and have thus become one of the most important sanatoria in India. Just south of this great height there is an extraordinary break in the level of the country. It is called the Pal-Ghat or Gap of Coimbatore, and joins the low lands of Calicut to those of the Cauvery basin. The railway from Calicut to Trichinopoli and Negapatam passes through it.

As the Deccan is entirely within the Tropics, the actual sun heat is always very great, and the length of the day varies very little. In the south the difference of time between the longest and the shortest day in the year is only one hour, and the difference of temperature between the hottest and the coldest day in the year is seldom more than $5^{\circ}$ or $6^{\circ}$.

\section{PASTURE AND TIMBER}

Pasture must be limited in a densely populated country ; but there is obviously room for it in a country parts of which do not receive a rainfall sufficient for 
agriculture. In India such a tract of land exists in the Lower Indus basin. A large portion of this is, as already mentioned, desert; but between the Luni river and the Aravalli Hills there is sufficient moisture for pasture, and there is a constant demand in the agricultural districts for horned cattle for labour purposes. Moreover, the dry slopes of the hills and mountains in the northwest are useless for agriculture; and the dryness implies very considerable extremes of temperature, demanding variety of clothing. Consequently, the product of Kashmir is wool from both sheep and goats, but mainly from goats. Silk is produced under entirely different conditions, but it, too, is found in Kashmir-wild, in the damp jungle of the lower valleys; and silk-worms are bred in the lower basin of the Ganges.

Timber covers much of the mountainous part of the country wherever the rainfall is sufficient, and special attention is paid to afforestation. The three most important kinds are teak, sal, and sandal-wood. The sal is the hardiest, and flourishes along the Himalayas; the teak is the most valuable, but is confined to the damp warmth of the Western Ghats; the stony soil, slight moisture, and intense heat of Mysore suit the sandal-wood.

\section{AGRICULTURE}

Wheat flourishes on the low dry plains of the Punjab and the elevated dry tableland of the Central Provinces. The centres in the Punjab are the great railway junctions of Lahore and Amritsar, though the nearness of the latter to Kashmir and railway facilities have drawn to it and the neighbouring town of Ludhiana a large shawl industry. The Punjab wheat is sent for export to Karachi via Multan. The wheat areas in the Central Provinces are on the northern plains-those of the Narbada basin in the north-west and those of the Mahanadi basin in the north-east. The great north-west centres are Sagar, Hoshangabad, and Narsinghpur, 
all of which have good railway communication; the great north-east centre is Raipur, which stands in the fertile Chhattisgarh plain on the main line between Bombay and Calcutta. Indeed, it is entirely due to railway extension that the Central Provinces have become one of the most important wheat areas in the continent. In 1876 wheat lay rotting on the land for want of transport ; now, since the completion of the direct line from Bombay to Calcutta, the receipts of wheat in Bombay are so enormous that at times the rent for warehouses accommodation runs up suddenly more than I00 \%. In I9I8 a crop of I0,000,000 tons was reaped off some $35,500,000$ acres.

Rice and Millet form the staple foods of the local population. Both are nutritious and prolific, but rice requires the more moisture. Consequently, while millet covers more than half of the whole cultivated area in a dry province such as Madras, rice must be grown on hot low land where floods are constant, and irrigation is easy. The latter conditions are only to be found in the damp north-east corner of the low Ganges basin, and round the coast. On the Bombay coast the success of rice, as that of teak, is due to the S.W. Monsoons; round the Bay of Bengal the crop is mainly raised on the deltas of the great rivers.

Cotton has the same climatic connexion with rice that wool has with wheat, as it requires a long, hot summer, with abundance of rain and irrigation; and it flourishes best in the Ganges valley and on certain " black-soil " lands of Bombay, the tenacity of the latter in retaining moisture compensating for the comparative smallness of the rainfall. The important railway and waterway junctions of Allahabad and Mirzapur are the centres in the Ganges basin; but the Bengal industry is handicapped by the cheapness and superiority of Egyptian and American cotton and by the persistent adulteration practised. The Bombay industry is in a healthy condition. The soil, especially on the plains of 
Khandesh, North Berar, and Wardha, is a fertile deconıposition of volcanic rock, abundantly supplied with lime; the direction in which the Tapti flows admits the S.W. Monsoons far up its valley; and the railway communication is excellent. Indeed, the conditions are so favourable that a fairly successful attempt has been made to introduce improved varieties of the plant, which have a longer staple, and are therefore more valuable for spinning finer qualities of yarn.

The almost unique commercial position of Bombay city is largely due to cotton. Owing to the ease with which coal can be imported, the city possesses no less than So mills, and about I70 out of the total 270 Indian mills are in or near the city, producing $75 \%$ of all the yarn and $87 \%$ of all the cloth made in Indian mills. Ahmadabad, which stands in the low Gujarat plain, where the Bombay and Baroda Railway crosses the Sabarmati river, also owes nearly all its importance to cotton ; and it is a curious proof of the moistness of the atmosphere that the Gujarat returns of clean cotton per acre are exceptionally high, though the land is solow that there is no condensing medium for the S.W. Monsoons, and therefore the cotton is largely dependent on irrigation from wells. The highest percentage of land under cotton in the whole country is, however, in Berar, on the plain of the Puma river, which is simply an extension of the "black-soil " Khandesh plain of Bombay. The Puma is a tributary of the Tapti; and Surat, the town at the mouth of the Tapti, gave its name to Indian cotton in the British market. The centres in Berar are Amraoti, Khamgaon, and Akola, all of which are on or connected with the main line from Bombay to Nagpur ; and Nagpur itself draws supplies of distinctly better cotton from the deep, damp valleys of the neighbouring rivers, especially from that of the Wardha. The finest cotton is grown, lowever, in the extreme south, i.e. the Madras-Trichinopoli-Tinnevelli district, where the rain comes in the Winter Monsoon, i.e. the 
N.E. Trade Wind, and so comes before the greatest heat, not-as farther north-after it.

Jute grows better on the sand-banks of the Bengal river system than anywhere else in the world. Like oil-seeds, it is somewhat a subsidiary crop to rice: but there the similarity ends. Oil-seeds are needed locally for outward application, food, and lighting purposes ; practically, the whole jute crop is exported, raw or manufactured. Jute is an extremely exhausting crop, and yet it cannot possibly bear the expense of manure. Consequently, it can be grown only on land which is flooded so heavily and so regularly that the alluvial deposit repairs annually the ravages of the crop. These conditions are found best between the lower courses of the Ganges and the Brahmaputra, especially between Goalpara and Purniah. Naturally, most of the export goes through Calcutta; but some of it goes through Chittagong.

Tobacco still is, as opium once was, a source of large revenue. The cultivation of the poppy in British India is now restricted to the United Provinces, where there is a Government factory at Ghazipur which still gives local employment to a considerable number of people. This is also the case with indigo, which is grown in Behar and Madras. The tobacco is grown mainly on the low lands along the Cauvery and the Brahmaputra rivers. The centre of the Cauvery valley is Trichinopoli, that of the Brahmaputra is Rangpur.

Tea grows wild in Assam. It is one of the hardiest of sub-tropical plants, and different varieties of it flourish equally well on the Himalayan slopes round Kangra and in the natural hot-bed of the Brahmaputra valley. The Kangra tea-gardens are situated in a beautiful valley north-west of Simla, and the "Himalayan" climate draws most of the European planters to this place or to Darjiling, where the climate is nearly as good. The Darjiling valley has abundance of iron in the soil and of vegetable mould as a natural top-dressing, and 
the slopes are quite steep enough to prevent moisture from settling round the roots of the plant; but all these advantages exist in Assam, and there are others. For instance, the moisture is much greater, and there are forests of teak. The latter, or some similar wood which contains no resin or aromatic oil, must be used for the tea-chests. The great centres are at Silchar, Sibsagar, and Dibrugarh; and a railway from Chittagong to Upper Assam supplements the river service.

At Kangra and Darjiling seed-beds must be protected from extremes of cold and heat, and the demand for quick-growing trees for this purpose hastened the introduction of the cinchona into India; but, of course, the Peruvian bark of the latter is itself very valuable in Tropical climates.

Among the peaks of the Western Ghats in Coorg and Mysore, where the water supply is plentiful, the heat great, and the accumulation of vegetable matter in the soil very deep, the main product is coffee; and any defect in beans exported from this district is probably due to bad ventilation en route, not to the original quality of the beans.

\section{MINERALS}

Coal-The production and consumption of coal have increased steadily in recent years, especially since 1906 ; but the resources of the country are still not fully exploited. The two chief fields are at Raniganj and Jherria, i.e. in Bengal and Behar, which produce $83 \%$ of the total Indian output. Smaller fields are found at Singareni, Wardha, and Makum. The total output exceeds $20,000,000$ tons, but there is little export, as the industrial development of India is going on more rapidly than the development of coal-mining-for which it is difficult to get efficient labour.

Amongst other minerals are manganese, mainly in the Central Provinces,- - gold, in the Kolar district of 
Mysore,-tungsten, in the Taroy and Mergui districts of Burma. Salt is evaporated round the coast, and is quarried in the Punjab.

\section{BURMA}

Burma, which is politically part of India, is more than twice the size of the United Kingdom. It consists of the valley and delta of the Irawadi, a low coast strip along the Bay of Bengal, and a wild hill region along the frontiers of China and Siam. The low lands produce enormous quantities of rice ; and the hills of Burma and the Shan States produce very large quantities of teak. Tobacco and bamboos are also important vegetable products; and the fact that the Irawadi is navigable for at least 900 miles, i.e. nearly to the Chinese frontier, makes it the great highway of commerce, especially between Mandalay and Rangoon.

The Tenasserim district, like the rest of the Malay Peninsula, is very rich in tin. It also has deposits of extremely fine iron ores. In the upper basin of the Irawadi there are numerous wells from which petroleum bubbles up in apparently inexhaustible quantities; and the same district contains also the most famous ruby mines in the world. Minor ports are Bassein, Akyab, and Maulmain. [For the tungsten, see above].

N.B.-Burma is the largest province of the Indian Empire, but is a quite distinct natural area.

\section{CEYLON}

Ceylon, which is quite independent of India politically, is a mountainous island nearly as large as Scotland, and it reproduces very nearly the typical climatic phenomena of the Southern Ghats. Tea, coffee, and cinchona are grown under precisely the same conditions as on the mainland; and most of the lower ground is covered with rice-fields and rubber or coco-nut 
plantations. There is also a large export of spices, especially cinnamon.

Ceylon also contains precious stones and minerals, and the pearl fishery off the north-west coast is one of the most productive in the world. The most valuable stones are rubies, sapphires, and cat's-eyes; and the most valuable mineral is plumbago. Colombo, the capital, has been made into a good harbour and coaling stationat the expense of Galle; the best harbour in the island, Trincomali, is comparatively useless owing to its situation on the north-east coast.

\section{BRITISH SOUTH AFRICA}

The position of South Africa makes the country of immense value to the Empire, for it commands a most important trade route in the water hemisphere of the globe. The Cape Province contains the only harbour of real value between St. Helena and Mauritius or Albany ; and in that harbour vessels, before entering the latitudes of " the Roaring Forties," can replenish their supplies of coal, including some from the Transvaal.

British South Africa, includes not only the four selfgoverning Provinces of the Union of South Africa-the Cape of Good Hope, Natal, the Transvaal and the Orange Free State, but also Swaziland, Basutoland, SouthWest Africa, the Bechuanaland Protectorate, and even Rhodesia, or at least Southern Rhodesia. That is to say, it occupies almost the whole area south of the Zambesi, and projects out into the water hemisphere so as practically to command its greatest trade route, British territory spanning the whole country from the Atlantic to the Indian Ocean.

The geographical conditions of British South Africa are superior to those of any other equal area of Africa ; but the surroundings are not faultless. The west coast is washed by the cold Benguela Current; and the S.E. 
Trade Winds, though very useful for carrying trade from the country, do not carry any rain to it. The east coast is washed by the warm Mozambique Current ; but there winds carry relatively little rain landwards, as the monsoons do not reach farther south than Zanzibar, and the S.E. Trades are affected by the heights of Madagascar. Consequently, no area of British South Africa south of Mashonaland has more than about 50 inches of rain a year. The rainfall from the south-east would, however, be much greater than it is, if the Draken-berge Mountains were farther from the sea or higher, especially if high enough to be covered with perpetual snow. Of course, the coastal strip between Port Elizabeth and the Limpopo has a greater rainfall than the rest; but that part is not very healthy.

South-west of Lake Tanganyika the wet winds off the Indian Ocean can penetrate far inland, and supply the sources of the Zambesi river system. Fortunately, that part of the country-besides being well-watered-is high enough to be generally healthy; and, as the soil is very rich, and there is abundance of gold, the countries of the Matabeles and Mashonas seem to have a great commercial future before them. Even in the best parts, however, a certain amount of coloured labour will probably be a necessity.

Relief-Quite generally, the area consists of a vast expanse of plateau at a height of one mile above sea-level, but with a narrow lowland round the coast, especially in the east, where the edge of the plateau-the Draken-berge-is highest and steepest. Like most plateau areas, South Africa is deficient in harbours, and has a very dry interior, especially in the south, where the plateau descends to the sea by three steps, and where the latitude involves scanty supplies of rain both from the Trades and from the Anti-Trades, the latter reaching as far north as Africa, only in the winter. These conditions are illustrated in detail in the various provinces. 


\section{THE CAPE OF GOOD HOPE}

\section{SURROUNDINGS}

The Coast is not more than I, 400 miles in length, which gives a proportion of only I mile of coast to I66 miles of surface, compared with I to less than 20 in Great Britain; and huge deposits of alluvium brought down by the great continental rivers do their best to spoil the few good harbours which have communication inland. The best natural harbour, Saldanha Bay, has neither supplies of fresh water nor communication inland, and is therefore useless except as a refuge during storm.

Table Bay is exposed towards the north-west, and is therefore not quite safe during "Anti-Trade" storms ; but the harbour is of immense importance to the British mercantile marine, and very extensive harbour works have been undertaken. Cape Town itself might be approached from the south-east via Simon's Bay; but that approach is equally dangerous, for Cape Agulhas extends a long way seaward beneath the surface of the water, strong currents sweep round the Cape, and the meeting of the cold Benguela with the warm Mozambique Current frequently causes dense fogs. The Bay has, however, such good anchorage that it has been made the headquarters of the South African Station; and the cold current brings abundance of fish to the bay.

Amongst the other places of call for the great "Liners," Mossel Bay is-naturally-only a roadstead ; and, though Algoa Bay is more like a harbour, Port Elizabcth is terribly exposed towards the south-east, i.e. the stormy quarter. East London is much better, thanks to the Buffalo river.

\section{SURFACE}

The relief is quite typical of the great plateau, rising in abrupt parallel terraces from a moist coast strip to 
dry flat-topped mountains, e.g. Table Mountain. The outermost terrace is very near the sea in the west and south, but towards the east is from 20 to 60 miles inland. The third terrace leads on to a large tableland, nearly half the size of England, called the Great Karroo; and, as the average elevation of this is 3,000 feet, the rainfall is very slight.

The Nieuwveld 'Mountains,' a continuation westwards of the Draken-berge, form the watershed of the whole country. From their southern slopes flow the chief rivers, the Guaritz, the Gamtoos, and the Sunday. The ridge rises in height-under different names, Winter-berge, Sneeuw-berge, and Storm-berge-towards the east; and this increase in height is accompanied by an increase in the amount of vapour brought landwards off the warm Mozambique Current. Accordingly, the Great Fish river and the other eastern rivers have a more permanent flow than those farther west. The Orange River, which is largely fed only by thunder rain from the northern slope of the watershed, is quite useless for navigation, partly owing to its variable volume and partly owing to the presence of a bar at the mouth.

The climate naturally changes on each terrace with increase of elevation and of distance from the sea; and it is further affected by the different capacity of the soil and the vegetation in different places for retaining moisture, and thus limiting the range of temperature. For instance, Grahamstown, which stands on the middle terrace, has an exceptionally even temperature because of its fairly heavy rainfall; and, as that terrace is formed of shale or conglomerate rich in alkali and lime, the grass crop on it is superb.

The climate also varies with the longitude. The rain in the east falls in summer, in the west in winter ; and, therefore, as at Grahamstown, the rain cools the heated air, and the clouds temper the summer sunshine. On the coast, e.g. at Port Elizabeth, the increased moisture and heat are as bad for Europeans as the more luxuriant 


\section{A COMMERCIAL GEOGRAPHY}

"sour grass" is for stock; but on the inland heights, e.g. at Aliwal North, the climate is magnificent, especially in winter. Indeed, the dryness and the pureness of the air, especially the absence of floating matter, make the interior an ideal place for consumptive patients-if their hearts are not weak.

\section{PASTURE}

Owing to the scanty rainfall and the rough character of the surface--which also impedes railway traffic, even on a narrow gauge-agriculture is scarcely possible except on the coast lands; and, as there is no great mineral wealth either, the colony will never be densely populated. Even for pasture the rainfall over the plateau, where evaporation and filtration are so rapid, might be heavier with advantage; and, of course, sheep and goats do not thrive on the coast lands. The latter are, however, useful for cattle; and there is a large demand for tranport oxen, as the ordinary " carriage" over the trackless plains of the interior is by wagon. Goats are much more numerous than cattle, and are of two kinds-native and Angora. The former are very hardy and breed fast, but the latter are much the more valuable. Most of them are kept on the Great Karroo, round Graaf Reinet ; and most of the mohair is sent for export to Port Elizabeth and East London.

The sheep, like the goats, are of two kinds-native and Merino; and in the very dry north-west area the native is even preferred. The Merino is elsewhere the most valuable animal in the colony, and the wool export was valued in I9r9 at nearly $£_{9}, 000,000$. The most important shecp farms are, again, on the Great Karroo. The latter takes its name from the Hottentot name for an edible shrub which grows on it, and which provides most valuable food for sheep; the thin red clay of its soil contains also saline elements most useful in sheepfood; and the clayey character of the soil retains and economizes the rain which docs fall -6 or 7 inches a 
year. Under such conditions each sheep requires at least 9 or ro acres of pasture; and even in the best watered districts, where one acre is sufficient, there is great mortality in a dry season. This, however, is largely due to bad farming, e.g. overstocking the farms or wearing out immense areas of good pasture by always bringing the sheep to the same kraal by exactly the same route.

Ostrich farming is a most characteristic industry, but it is in the hands of a few rich capitalists. The reasons for this are that it requires special knowledge, and is so dependent on "fashion" that there is great risk of heavy losses. The wild ostrich has become very scarce; but such a number of tame birds have been bred, to replace the wild ones, that the price of the feathers has actually decreased, and the decrease in price has largely increased the demand. The centres of the industry are Uitenhage and Grahamstown, on the edge of the middle terrace, where the grass is rather too luscious for sheep. Both towns have railway communication inland and with the sea; Uitenhage is on the line from Port Elizabeth to Graaf Reinet, and Grahamstown is on the line from Port Alfred to Pretoria via Bloemfontein and Johannesburg.

\section{AGRICULTURE}

Naturally, the parts of the country most suitable for agriculture are those which have the heaviest rainfall ; and even in these irrigation is a necessity. This, however, is rendered difficult and expensive by the depth of the channels which the rivers have ploughed for themselves during the floods of centuries; and yet the profits and prospects of agriculture are not such as to encourage lavish expenditure on large irrigation schemes, even with the assistance of Government.

Maize, or "Mealies," is the common crop and food of the people, and is admirably suited to the soil and 
climate, being a native of high tropical plateau. It is naturally confined very much to the coast districts and river valleys; and the only good returns are obtained in the south-east between Uitenhage and King (William's Town). Grahamstown, which is almost half-way between the two, has the heaviest rainfall recorded in the colony-about 42 inches.

Tobacco is grown with some success in the south, especially round Oudtshoorn. There the rich limestone formation, the shelter of the Zwarte Berge and the Lange Berge on the north and the south, the proximity of the sea, and the presence of extensive forests between the sea and the crest of the Lange Berge, seem to guarantee permanent success to the planters. The port of the district is the open roadstead of Mossel Bay, and the railway centre is Prince Albert. Indeed, the transit accommodation, the rich soil, and the number of streams, make the land between Oudtshoorn and Cape Town one of the most valuable parts of the whole colony; and the climate is perfectly healthy.

Viticulture is also becoming a very important agricultural industry, at all events in the west of the colony. The vine grows very luxuriantly there, as the dry, warm slopes of the lowest terrace in the south-west supply in that latitude an ideal site for vineyards ; and, if only the manufacture of the product was scientifically conducted, there would probably be an enormous development in the wine and brandy export. There are three centres, all of which have rail communication with Cape Town ; and the ease with which cork-dust can be imported from Lisbon, and the nearness of Cape Town to England, enable the fruit itself to be put on the London market in the most magnificent condition during the winter, several weeks sooner than Australian grapes can be. Indeed, one centre is in the very suburbs of Cape Town along the line to Simon's Town, the most famous vineyards being those of Wynberg and Constantia. Another, almost equally near, is round Paarl and Stellenbosch, 
which are on the main line from Cape Town to Kimberley. Unfortunately, however, the Stellenbosch district has suffered so terribly from the ravages of the Phylloxera that some of the vineyards have been replanted as orchards; in other cases American varieties of vine have been imported. The third centre is in the Breede valley, where the yield per acre is very large, owing to the scientific culture ; but the area under the vine there is comparatively small.

\section{MINERALS}

Coal does exist in considerable quantities, and is quarried at Molteno, Cyphergat, and other villages in or near the pass by which the Eastern Railway crosses the Storm-berge; but the quality is very poor, and the price is absurdly small compared with that of imported English coal. The conditions under which the work is carried on, however, make the cost of production small, and allow European miners to be employed in spite of the heat.

Copper is also found in the colony. It exists in valuable quantities in the old formation of Namaqualand, between the Orange and the Buffels rivers. The centre of the mining is Ookiep, which is connected by nearly Ioo miles of mule tramway with the little roadstead of Nolloth.

Diamonds, however, are the great mineral product of the Cape, and realized more than $£ 5$, I00,000 in I9I7. The mines are in the blue clay of Griqualand West, which is traversed by the Orange, Vaal, and Hart rivers, and by the Western Railway (from Cape Town to Taungs, Vryburg, and Mafeking). Kimberley is, of course, the centre of the industry; and its climate is so healthy that half of its population (of 35,000 ) is European. The soil in the neighbourhood is a rich red loam, and the total water supply by rain (20 inches) and river is sufficient for all ordinary purposes. The best watered land, and 
that most favourably situated also for irrigation, is the low plain between Barkly West and Warrenton in the fork of the Hart and Vaal rivers.

Bechuanaland, formerly a separate colony, is a fine plateau shut in on the north and the west by the Molopo river and on the east by the Transvaal. It is very healthy, and-in spite of the extreme dryness-much of the soil is so rich that successful pastoral and agricultural industry is quite possible with irrigation; and where, as along the Setlagoti river in the north-east, there is really abundance of grass, wood, and well-water, the country is admirably adapted for stock-farming. The three chief centres of population-Taungs, Vryburg, and Mafeking-are all along the eastern border, and all have direct rail to Cape Town and Port Elizabeth. Taungs and Mafeking have also river accommodationthe Hart and the Molopo respectively. Taungs, as the farthest south, collects maize, pastoral products, and wood for Kimberley; Mafeking, as the farthest north and the original terminus of the railway, trades with the natives of the Bechuanaland Protectorate and the miners of the Transvaal. The only central town is Kuruman, near which the "blue limestone" formation produces a "sour grass" on which no stock can thrive, and milch cows actually die.

\section{BASUTOLAND}

Basutoland is a high plain, about twice the size of Yorkshire, west of the Draken-berge. The Caledon river forms its western boundary, while the Orange river drains and waters the central plain of the country ; and the height of the Draken-berge (Io,00o feet) guarantees both a splendid climate and a supply of water even in mid-winter. Unfortunately, Europeans are forbidden to settle in the country, and the Basutos themselves are more inclined to pastoral than to agricultural farming; 
but both climate and soil are excellently adapted for wheat, and the British Resident at Maseru is paying special attention to the development of all the resources of the country.

\section{SOUTH-WEST AFRICA}

The old German territory behind Walfish Baywhich was never German-is administered by the Union of South Africa under a mandate. The coastland and most of the southern part of the area are desert or semi-desert, but in the north there is enough rain for some cultivation, e.g. lucerne. But the wealth of the area is in the diamonds of the coastlands south of Walfish Bay and the copper of the Tsumeb district towards the north-east.

Walfish Bay is an excellent harbour; but the fact that it was British caused the Germans to develop the much inferior harbour of Swakozmund.

\section{NATAL \\ SURROUNDINGS}

Coast-Natal is about two-thirds the size of Scotland; but it has only 200 miles of sea-coast, and that is all on one side, the south-east. Moreover, in the whole length of it there is only one harbour, Durban; and, as that one monopolizes not only the entire foreign trade of Natal, but also much of the Transvaal and Orange State trade, it has become one of the most important places in South Africa. Indeed, if the Draken-berge were not such a formidable obstacle, Durban would be the natural outlet for all the trade of these two provinces. The bay of Port Natal is, however, by no means an ideal harbour, as there is a shifting bar across the entrance, and the water inside is shallow. Durban 


\section{A COMMERCIAL GEOGRAPHY}

itself is well protected by a spur of land which juts out south-eastward into the bay.

The height of the Draken-berge varies from 6,000 to Io,000 feet, and there are only a few steep passes across the range. A large traffic has, however, been carried on (export and import) by means of these passes, oxen - the usual beasts of burden in the colony-being as much surer-footed as they are slower than horses. Now lines of rail tap the Transvaal and the Orange Free State; and, as the gauge is only 3 feet 6 inches, the expense of making and working the line is minimized, though the gradients are very stiff.

The frontier in the north-east and south-west presents no obstacle to traffic; and, as almost all the land in both directions belongs to the Empire, this is a distinct advantage.

\section{SURFACE}

The Relief of Natal, like that of the Cape to the west and that of Zululand to the east, is very typical, the land rising in steep terraces, the innermost of which is from 80 to I20 miles from the sea.

The height of this innermost terrace, which is practically the Draken-berge, and its nearness to the warm Mozambique Current, guarantee a much greater rainfall (including some snow) than in the Cape; and the steepness and frequency of the terraces, though it makes continuous navigation impossible, even on the largest rivers, supplies abundance of water " power " for motive and irrigation purposes. The heavy rains have, however, cut up the surface so much that navigation, even between the Falls, is impossible; and they have also caused the rivers to plough such deep channels that irrigation by gravitation-the only cheap methodis in some places impossible. The heaviest rains fall in summer during thunder-storms, when the thunderclouds temper the summer sunshine; the smaller 
rainfall in winter is sufficient for ordinary purposes, as the sun's heat is so much weaker.

The Character of the Country, however, naturally gives rise to a considerable variety of climate and productions; and, fortunately, Europeans can work with impunity everywhere except on the coast strip. There, too, the productions are of a kind for which cheap labour is absolutely essential, e.g. sugar; and this can best be provided by coloured labourers, natives or coolies. The native population is proportionately very large, 960,000 out of $\mathrm{I}, \mathrm{I} 95,000$; but, as it is composed mainly of Kafirs, whose wants are limited to food, drink, and a small apron, native labour is almost unprocurable. The coolies work well, but are much given to drink.

The coast strip, which is from 25 to 30 miles deep, has naturally semi-tropical climate and productions; and, as the soil is generally a light sandy loam with patches of clay and abundance of organic matter, it is well suited to maize, sugar, tea, etc. Maize is, of course, largely cultivated for food, especially in the eastern half. Sugar cultivation has considerable attractions for small farmers, and forms a principal product of the colony; but a good deal of the cane is grown only to serve as fodder. The two sugar centres are Isipingo and Verulam, both of which have direct rail to Durban. Tea is largely confined to the Lower Tugela district, where the soil and the climate are distinctly favourable to this crop. Most of the product is sent up-country. This coast strip is also rich in timber, much of it being Eucalyptus, which has been extensively planted from sanitary as well as from commercial reasons.

Above the coastal terrace there is a wide stretch of rich loamy "midlands"-round Pietermaritzburg, Richmond, and Greyton-which is used for mixed farming; and behind this are the uplands. Cattle (for draught) and horses are reared in the midlands, where they are free from lung diseases, which are so prevalent 
on the coast that mules have to be employed on the sugar plantations; and sheep and Angora goats are reared on the uplands, the goats thriving on the higher and drier land and requiring the less attention. The total export of wool and mohair, which-unlike the cattle trade-is entirely in the hands of Europeans, is valued at about $£ 700$,000 a year ; and, in connexion with a large skin trade, extensive plantations of wattle are being made for tanning purposes. There is a considerable export of skins, hides, and wattle bark.

The only mineral of importance is coal, which is confined to the extreme north. There, on the upper waters of the Buffalo tributary of the Tugela, very good coal is worked at Newcastle and Dundee. Ladysmith - which is the junction for the Transvaal traffic with the main line from Durban via Pietermaritzburg to Harrismith (Orange Free State)-is the commercial centre of the district, and has rail communication with the mines. The total area of the coal-field is probably great, extending north-eastward as far as Vryheid.

\section{THE BECHUANALAND PROTECTORATE}

The Protectorate reproduces the main features of the Bechuana region of the Cape province, all its valuable land being towards the east along the Limpopo river. Indeed, in the west is the Kalahari Desert. In the south-east round Kanya, the plains of the colony break into undulating land, covered with excellent grass and well wooded. In the north-east, round the now ruined Shoshong, the land is equally good; and, if the summer rains were properly stored, much might be done by irrigation, though the soil is rather porous. The country was taken under British "protection" for the special purpose of continuing " the Cape to Cairo railway" northward from Mafeking. But European immigrants, especially thosc of British extraction, cannot 
compete with the natives or the Boers in such a country.

The better parts of the land grow immense quantities of "mealies" and even of European fruits and vegetables, to supply the miners on the Matabeleland and Mashonaland gold-fields.

\section{ORANGE FREE STATE AND TRANSVAAL.}

The two old Dutch Republics consist of a typical area of the broad high plateau, with an undulating kopjestudded surface, entirely cut off from the sea by the Draken-berge. The plateau generally is known as the Veld, and sinks gradually from the water-parting of the Witwatersrand to the Limpopo and the Orange rivers.

The Transvaal, or Limpopo slope, falls in wide terraces - the High Veld, the Middle Veld, and the Low Veld; and it has an area about twice as large as that of the Orange Free State, or Orange slope. The fact that the plateau falls within the Belt of Capricorn Calmsi.e. has no regular winds blowing into it for at least half the year-implies that its rainfall is uncertain and limited, Bloemfontein having about $2 \mathrm{I}$ and Pretoria about 26 inches a year; but the nearness to the sea and the height of the Draken-berge guarantee a fairly good river-system, of which the Vaal is the centre. The climate is, however, too dry in most places for treegrowth, though it is very healthy and very favourable to pasture.

The High Veld, the highest and driest part of the Transvaal Province, is also exceedingly rich in gold, supplying practically the whole gold-export of South Africa (over $£ 35,380,000$ in I9I9). Johannesburg, the centre of the richest deposits on the southern slopes of the Witwatersrand, has sprung up since 1885 into a city of over 140,000 persons ; and it is typical of a great 
mining centre in a " new " country that at the last census $80 \%$ of its population were males. There are also rich gold-fields in the Draken-berge valleys, e.g. in the De Kaap district round the towns of Lydenberg and Barberton. The colony also produced in I9I7 over 6,640,000 tons of coal, and nearly $\mathrm{r}, 000,000$ carats of diamonds ( $f$ I $2,670,000$ value).

On the rolling veld of this higher level (over 5,00o feet) most of the stock-sheep $(4,500,000)$, goats, cattle and horses-are pastured, though in the dry winter months many of them are taken down into the Middle Veld or to the sea-ward edge of the province. Parts of the area, too, are suitable for agriculture-mealies, tobacco, wheat, etc.-especially round Pretoria.

The Middle Veld, or "Garden of the Transvaal," is better watered, and has better soil than the High Veld, and so has become a district of " mixed " farming ; it produces specially tobacco and mealies (maize), e.g. round Pietersburg and Nylstroom.

The Low Veld is the forested valley of the middle Limpopo, and produces plants typical of the lower level and damp heat-coffee and sugar; and ivory is exported from the parts which are still frequented by elephants. As it is still infested with the tsetse fly, it is useless for cattle in the meantime.

The great centre in the Transvaal is round .Johannesburg and Germiston, from which lines radiate via Heidelberg and Standerton to Natal, and via Krugersdorp and Potchefstroom, Klerksdorp and Bloemkof, to the Bechuanaland ${ }^{\mathbf{1}}$-Cape Province frontier near Frontier Springs, as well as to important centres in the colony itself, e.g. the Vereeniging and Ermelo coal-fields.

The natural outlet of the Transvaal is obviously the Portuguese harbour of Laurenço Marques ; but Imperial, historic, and economic links between London and Johannesburg, and the fact that the chief exports, gold

1 The old Bechuanaland Colony is now formally included in the Cape of Good Hope Province. 
and diamonds, can bear very heavy freight-dues, cause the mass of the traffic to move via the Cape in spite of the longer railway haul.

The Orange Free State is much more level than the Transvaal, and is too high and too dry everywhere to have any unhealthy areas such as the Low Veld; but otherwise it resembles the Transvaal area, being partly mining and partly farming. The mineral wealth is mainly in diamonds, e.g. near Jagersfontein and Fauresmith, and coal, e.g. between Kroonstad and Heilbron; the chief cattle-markets are in the wetter east, especially the Caledon valley, e.g. at Ladybrand and Smithfield.

The Railway System is important. The main route runs in an almost direct line from Norval's Pont on the Orange River (where it joins the Cape Province line to Port Elizabeth) to the gold-field of Pietersburg (en route for Bulawayo via Rhodes Drift and Tuli) through the pastoral and political centres of Bloemfontein and Pretoria ; and it is joined at the exceedingly important junction of Germiston (formerly Elandsfontein) by the line from Newcastle (Natal) via Standerton and the Heidelberg gold-field, and at Pretoria by the line from Delagoa Bay via Komati Poort and the Middleburg coal-field.

There are also some important branch-lines-e.g. from Springfontein to Bethulie, the frontier junction with the line to East London; from Kroonstad to the coal-field of Vierfontein and to Bethlehem (for the Natal connexion), also reached direct from Bloemfontein; from near Viljoen's Drift to the coal-field of Heilbron.

\section{SWAZILAND}

As its position suggests, this area is really part of the Low Veld of the Transvaal region, but it is more healthy than the actual Transvaal portion. Under its native chiefs it grows good crops of maize and tobacco, and 
some successful experiments have even been made in cotton-growing. Its chief mineral wealth is alluvial tin, which was exported in I920 to a value of nearly $£ 70,000$.

\section{RHODESIA}

The Relief both north and south of the Zambezi is quite typical of the great eastern plateau, but its characteristic features are on a relatively small scale.

Southern Rhodesia consists of the countries once known as Matabeleland and Mashonaland. Even now the region is not yet properly settled, but it is of extreme importance. There is no doubt that it is, on the whole, perfectly healthy for Europeans with reasonable precautions-that it is magnificently watered-that the soil is exceptionally fertile, the crops of maize and Kafir corn being enormous-that it is distinctly rich in gold, Matabeleland especially round Bulawayo and in the quartz and blue slate formation of Tati, and Mashonaland especially at Hartley Hill, Fort Salisbury, and Fort Victoria. The Mashona area is the better of the two; the soil is richer, the water supply more constant, the distance from the ocean-via the Pungwe Valley Railway-less, the gold-fields larger, the natives more peaceful and industrious, and the particular products more immediately useful. For instance, the dense timber is most useful in the mines and for building purposes, especially as some of it is hard enough to resist the ravages of the white ant; the quantity of fruit (from lemons to even a species of date-palm), game, and honey, are helping to supply the immediate demand for food; and the presence of extremely good wild tobacco has special significance in view of the fact that the country is being developed by a mining population.

The two great political and commercial centres are Bulawayo and Salisbury, which are busy railway junctions at the opposite ends of the great water-parting 
of the Matoppo Mountains. The earlier railway connexion via Umtali to the Portuguese harbour of Beira favoured Salisbury at first; but the balance of power is now moving westward in the direction of the Wankie coal-field and the Victoria Falls, and this is naturally favouring Bulawayo. Gwelo is an important junction for the Selukwe gold-field.

Northern Rhodesia is at present of little importance except as preserving a continuity of British territory up to Lake Tanganyika, but the Loangwa valley is a valuable "Line of Least Resistance" for the movement of trade, though not being followed by the Cape-toCairo ${ }^{1}$ Railway, which goes via the Victoria Falls and Broken Hill. Its exports include ivory and rubber, cotton and tobacco.

\section{TROPICAL AFRICA}

The Egyptian area in the north has somewhat the same transitional position as the Rhodesian area in the south. Even before Egypt became a British Protectorate, the British Sphere of Influence in Egypt extended southward into the Nubian steppe, where Khartum commands the approach from the south and the west, and Berber that from the north and the east, the eastward approach being via Port Sudan or Suakin. This formed a valuable base between the British possession of Somaliland-with fairly good harbours at Berber and Zeila and a fine strategic outpost in the island of Sokotra -and the Suez Canal, our interest in which may be gauged from the fact that the Great Circle, i.e. the shortest possible route, from the most distant portion of our oceanic empire, New Zealand, to the nearest portion, Newfoundland actually passes through the canal.

Of the total area, the "Egyptian"-including the Anglo-Egyptian Sudan is the largest, with a mileage of

${ }^{1}$ This connects with the Katanga copper area of the Belgian Congo. 


\section{A COMMERCIAL GEOGRAPHY}

over $\mathrm{I}, 000,000$; but the eastern area is well over $75^{\circ}, 000$ square miles, and the western approaches 500,000.

\section{WEST AFRICA}

In the western area the British domains include the Gambia Colony, Sierra Leone, the Gold Coast, Nigeria, and part of Togoland.

The Gambia Colony and Sierra Leone are entirely isolated by French territory, but the Gambia estuary makes Bathurst a good harbour, and the Freetown peninsula shelters the Rokella estuary so perfectly that the harbour is the best along the whole of this coast. The damp heat and rich soil-largely volcanic-account for the typical products-palm oil, kola, ground nuts, and rubber.

The Gold Coast produces actually more gold than when it gave its name to the English guinea coin, but its chief products now are palm oil, rubber, and ebony. Its old centres of Accra and Cape Coast Castle are also less important than the railway centres of Sekondi and Kumasi, the railway being more useful than the Volta navigation.

Lagos, on the contrary, though an old centre, is becoming more and more important, partly because it is itself an island harbour, and partly because it is now included politically in its natural hinterland, Nigeria ; and since the "Ibadan" railway was extended, Lagos has got valuable trade with Sokoto, Kano, and other centres in Northern Nigcria. The railway from the Niger port of Baro joins the main line (via Ilorin and Zungeru) at Minna. Southern Nigeria thus finds an outlet for its oil and rubber via the Benué river and the "main-route" harbours of Akasa and Asaba rather than by the old "Oil-river" ports of Bonny and Old Calabar. The railway has also greatly facilitated the export of cotton, which is one of the most important crops in Northern Nigeria, as it is also in Togoland. 


\section{EAST AFRICA}

Britisl East Africa, again, is a typical section of the great eastern plateau of Africa, but has had three special advantages. The first is that the climate-on the north of the Equator and in the lee of the Abyssinian highland -is healthier than that of the similar physical area south of the Equator which was owned by Germany; and, therefore, it was easier to settle. The second is that it includes Uganda, which-though not very healthy -is very fertile, and commands the source of the White Nile, i.e. that part of the river-system which maintains the most constant flow. Again, it includes not only the fine harbour of Mombasa, ${ }^{1}$ with the easy Sabaki valley route-followed by the railway - to the Victoria Nyanza, but also the island of Zanzibar, which still enjoys most of the commercial advantages which once made it the headquarters of the Slave Trade, and which certainly dominates the coast of Equatorial East Africa. Coffee, cotton, rubber, and ivory are typical products of Uganda, as coco-nuts, sisal, and cloves are of the coast-lands,cloves specially in Zanzibar and Pemba.

The political units included in the area are the Nyasaland Protectorate, the Tanganyika Territory (Mandate), the Kenya Colony, and the Protectorates of Uganda and Zanzibar.

Nyasaland is an exceedingly promising agricultural area, producing excellent coffee and cotton. The chief centre is still Dr. Livingstone's old mission-centre of Blantyre, which has railway connexion with the tradeports of Chiromo and Port Herald, and so to a "freezone" in Portuguese territory at Chindé, on the most useful distributary of the Zambesi. The capital is at Zomba, which is healthier than Blantyre.

The Kenya Colony is now the official title of the old British East Africa Protectorate, and certainly the

1 The best port of the island is known as Kilindini (" Deepwater-place ") on the west shore. 
snow-capped cone of Kenya is one of the most interesting features of the area. It consists essentially of a coastal plain and a continental plateau, the height of which allows European crops to be grown and a European population to live in health. At the same time the height and the latitude combine to cause heavy tropical rains from which the great lakes and the great rivers are fed. Coco-nut products and sisal hemp, coffee and cattle products from the savannahs, and ivory from the equatorial forests, are typical products.

The most important political and economic feature is the "Uganda" railway - from Mombasa via the capital of Nairobi to Port Florence, and there is regular steamship ${ }^{1}$ connexion between Port Florence and the Uganda capital of Entebbe.

Uganda is still seriously hampered by the terrible scourge of sleeping-sickness, a fly-borne disease; but it is extraordinarily fertile, and is already exporting considerable quantities of excellent cotton. The average height of the area is not much above 4,000 feet, but the railway from Mombasa rises to nearly twice that height before it drops into the Uganda "basin." The chief cotton area is round Lake Kioga, which is linked by rail to the Victoria Nyanza.

The Tanganyika Territory was, of course, formerly German East Africa. In relief and climate it more or less resembles the Kenya Colony, but it is less healthy, especially in the forested coast-lands. These are, however, very fertile, and so is the Tanganyika Lake basin ; but the intervening land, though healthy, is poorer and less populated. Europeans have started plantations, e.g. coffee and cotton, on the Kilimanjaro and Usambara highlands, both connected with the coast by rail. On the coast the special crops are rubber and sisal, and coco-nut products and sugar are also important. Inland, coffee, cotton and tobacco have been the chief products,

1 Some anxiety is being caused by the steady decrease in the depth of the Victoria Nyanza. 
but the south-eastern part of the Tanganyika Lake basin is covered with the oil-palm, and this offers great possibilities, especially if there were easier transport. The trunk line from Dar-es-Salaam to Kigoma is of vital importance, but there is need of rail connexions with both Lake Kivu and Lake Nyasa. The hinterland of this line, however, is inhabited by more backward peoples than are found in the hinterland of the Uganda railway.

Zanzibar is still a great central market, but can never regain the importance which it enjoyed as the terminus of the slave caravan to Ujiji ; and the mainland ports of Mombasa, (linked by rail to the mainland) and Dar-es-Salaam, with their railways, have now infinitely more hold on the interior. The "railway" port of Tanga has similarly affected the importance of Pemba, the other main clove-grower of the world next to Zanzibar.

\section{THE NILE LANDS}

Five natural regions are included in the Nile basinLakeland, Savanna, Steppe, Desert, and Delta ; the Delta and Desert coming into what may properly be called Egypt, while the Savanna and Steppe belong to the AngloEgyptian Sudan.

The savanna lies right between Lado and Fashoda, where the dead level and the convergence of streams from east, south, and west combine to give rise to much marsh and sudd growth, which is very adverse to navigation. The land makes fine pasture, however, and rubber and ivory are collected.

The steppe zone between Fashoda and Khartum is much healthier, and the river is a fine waterway, by which wheat and tobacco, gum and cotton are collected. Irrigation is beginning to be developed, e.g. at Sennar, and there is a railway via Sennar to El Obeid.

The desert zone is of more interest than importance 
apart from the one vital question of extending the water-supply. The only places of any importance are those where the navigation is naturally impeded by cataracts, e.g. Aswan, Wadi Halfa, and Berber, the last place having railway links both with Wadi Halfa (below the Second Cataract) and with the Red Sea at Port Sudan and Suakin.

The valley, in a special sense, is roughly the portion between Aswan and Cairo, i.e. the portion where periodic flood is giving place to perennial irrigationfrom the great dam, and so allowing the growth of sugar and rice and cotton during the summer in addition to the ordinary winter crops of maize and wheat and millet. The only important place in this section is Asiut, where there is a barrage.

The Delta and the Fayum have the advantage of wider area than the valley, and it is here that the great cotton crop is mainly grown, which accounts for about fivesixths of the total value of Egyptian exports. Considerable harm has been done, both to quality and to quantity, by over-watering and insufficient drainage; but this is now being remedied. Two distributaries of the Nile, those leading to Rosetta and Damietta, are kept open for navigation; but neither harbour can compare with the great commercial centre of Alexandria, on a sandspit between the Mediterranean and a lagoon, and westward of the distributaries so that the silt from the riverblown eastward by the prevailing wind--never troubles the harbour. The squalid little town of Suez is much less important than the Mediterranean coaling-station of Port Said and than the railway junction of Ismailia, with its freshwater canal via Tel-el-Kebir to Cairo.

Cairo, however, is by far the most important town in the whole area. It stands on the high castern bank of the river, at the apex of the Delta, thus holding the balance of power between the valley and the Delta, and commanding the approach from east or west. The eastern approach is now much the more important, 
especially since the linking up of the Egyptian and Syrian railways.

The Suez Canal is about 90 miles long, more than 20 of which are through the Bitter Lakes, but there are no. locks, and the Red Sea tide is "lost" on the lakes. It cannot take the largest ships afloat, but the width of the bed (I 20 feet) and the depth ( 3 I feet) have been steadily improved. About $60 \%$ of the vessels using it are British, and-so far as the Empire is concerned-it has not been seriously affected by the Panama Canal.

\section{NEIV ZEALAND}

\section{SURROUNDINGS}

New Zealand is sometimes called " the Britain of the South," and there are many points of resemblance, e.g. its maritime position, its coast line, its division into two large islands, its scenery, its size, and its climate; and this causes the productions of the two countries to be very similar. New Zealand is, however, much nearer to the nominal Equator; its northern half is the hotter ; it is much farther from the nearest land; it is in the centre of a water, not a land, hemisphere; and it draws some of its revenues from very different sources.

The Position of the islands is directly in the path of constant west winds blowing over thousands of miles of sea, and this sea for a long distance westward is shallow and warmed by equatorial currents. Consequently the coasts are never blocked by ice, and the range of temperature is slight; but the proximity of the cold Antarctic water, the great length of the colony compared with the breadth, the large proportion of coast, and the division of the land by Cook Strait, cause many points of the island to be liable to severe storms of wind. The distance of the colony south of the Tropics saves it, however, from tropical cyclones.

The coast is very long and very broken, but the 
harbours are irregularly distributed. For instance, on the west coast of the South Island there is no natural harbour, though Westport and Greymouth have been converted into fairly good ports. (Cf. Timaru.) Even in the North Island, where the mountains do not run so closely along the shore, drifts and the prevailing west winds spoil the otherwise good harbours, e.g. Manukau. On the east coast there are at least two good harbours in each island-those of Wellington and Auckland in the North Island, and those of Lyttelton and Dunedin in the South Island. Russell, in the extreme north of the colony, and Bluff, in the extreme south, are also fine natural harbours. Port Lyttelton, the harbour of Christchurch, has the largest trade of all the South Island harbours, partly owing to the density of the population behind it, and partly owing to its excellent accommodation for vessels. It has two breakwaters, enclosing IOO acres of harbour with $2 \frac{1}{2}$ miles of wharfage ; and the approach is very safe, being-like the approach to all the east coast ports-well lighted and sheltered by the island itself from the "Brave West Winds" in "The Roaring Forties."

Port Chalmers, the harbour of Dunedin, is equally good. It is connected with Dunedin both by water and by rail, its wharfage is excellent, it possesses one of the largest graving-docks in the Southern Hemisphere, and is near excellent coal at Kaitangata.

Port Nicholson, the harbour of Wellington, is really on Cook Strait, which has one or two other excellent, but less important, harbours, e.g. Nelson and Wairan. It is a land-locked bay with deep water throughout; it has a convenient quarantine station on an island out in the bay, and is, of course, the port of the capital of the colony, and does the largest trade.

Auckland has practically two harbours, as the isthmus on which it stands is only 6 miles wide. Onehunga, however, the western port, is on Manukau Harbour, and thus is comparatively useless. Waitemata, the eastern 
port, has very large docks; and, as the main line of rail northward must cross the Auckland isthmus, a very considerable trade must pass through the city.

Russell is a really fine natural harbour, sheltered by Ioo islands; vessels of any tonnage can make the port in any weather and at any state of tide; but it has less economic importance than Napier or Gisborne. Campbelltown (Bluff) enjoys similar natural advantages, but it is very much more important economically.

\section{SURFACE}

The North Isiand is lilly throughout, but the elevation is greater in the eastern haif than in the western. Its lighest peaks are, however, volcanic; and the shape prevents the formation of glaciers on their sides. In such a latitude this is no drawback, as the ordinary rainfall is sufficiently heavy and regular to maintain the rivers even during the summer. The height of the surface, the direction of the mountains north and south so that they present a full face to the west winds, and the narrowness of the country, make these rivers too short, too liable to floods, and too rapid to be of any use for navigation.

The South Island is rather larger than the North Island, and more marked in its features. It is traversed throughout its entire length by a range of high mountains, called the Southern Alps, which hugs the west coast. The nearness of this range to the sea, its height, and the character of its formation, cause precipitation to be very complete and very sudden, and admit of the existence both of very large glaciers on the range and of considerable plains along its eastern base.

\section{PASTURE AND AGRICULTURE}

English grasses naturally thrive wherever there is light and moisture ; and the mild, insular climate enables growth to continue practically throughout the whole 
year, and obviates the necessity for winter-housing of stock. Moreover, much of the reclaimed land-at least, in the North Island-was of volcanic formation, hilly, and covered with dense bush. Volcanic soil produces very good grass, and is very healthy for stock to feed over; the New Zealand rainfall is so regular that there is no hesitation in "felling" the bush; the cheapest method of felling is by burning, and the potash makes an excellent top-dressing for grass. In recent years great progress has been made in dairy work, resulting in a large export of cheese and butter, especially to England, cheese in I920 being the third export (in value) of the colony. There is a certain amount of cattle-farming, but the regular stock is sheep; and the staple products of the colony are wool and frozen mutton, the latter to the value of over $£ 4,000,000$. In I9I9 there were over $25,000,000$ sheep in the colony.

Grain is grown in considerable quantities, especially on the plains of the South Island. Wheat does best in the warmer and drier provinces of Wellington and Marlborough ; but most of the crop-as of oats-comes from the provinces of Canterbury and Otago.

Timber and flax are, however the characteristic products of New Zealand. Thick forests cover the centre of the North Island and the western slopes of the Southern Alps. The most valuable tree is the kauri pine, which grows on steep, clayey banks near the sea; it supplies both timber and gum. The timber is very tough, straight, and durable, without being hard to work; the gum, which strongly resembles amber, is dug up on the sites of old kauri forests-sometimes from a great depth-and is converted into jewellery and into expensive kinds of varnish. The timber along the Southern Alps is extremely useful for the shafts, tunnels, and galleries of the Nelson and Westland gold-mines; and to the east of the Alps there is a considerable area under fruit-trees, especially on the plain of Nelson and along the Clutha valley in Otago. 'The low alluvial 
plain, the shelter afforded by two spurs of the Alps, and the even climate of Nelson, favour the peach ; in the Clutha valley the greater extremes favour the apple; but Auckland and Hawke's Bay are the chief fruit areas.

In connexion with these areas of timber, and with the meat trade of the colony, a considerable tanning industry has sprung up, especially round Christchurch, the most useful barks being those of the birch and the tanekaka. The bark of the latter is largely exported to Francevia London-for dyeing kid gloves.

The phormium or flax grows in the Waikato valley. The river is nearly 200 miles long, but is of very little value for navigation; and, even if it were really navigable, it empties through the wind-beaten, sand-clogged west coast. Its great use is, therefore, as a drain and a fertiliser. Where its banks are low, it overflows and forms huge marshes. In these the flax grows with remarkable luxuriance. It is very tenacious and durable, but somewhat coarse. Consequently, it is used mainly for rope-making.

\section{MINERALS}

The mineral wealth of New Zealand is practically confined to coal and gold, though oil has been struck in the Taranaki district.

The coal is found in several parts of both islands, and noost of it is very conveniently situated. For instance, in the North Island patches of coal run from Russell to Whangarei, the two chief harbours in the extreme north. The same line reappears at Drury, just south of Auckland, and runs along the Waikato valley, between Mercer and Rangiriri, to Newcastle (Ngaruawahia); and the coal from this district serves both the steamer and railway traffic of Auckland city itself, and the iron-works of its western port, Onehunga.

The mines in the South Island are richer and even more conveniently distributed. The most valuable 


\section{A COMMERCIAL GEOGRAPHY}

ones are along the northern half of the west, i.e. the wet, coast, where they are confined almost entirely to the Province of Nelson, though a little is found in Westland. The coal is very near the sea, and all of very excellent quality. The two great harbours are Westport and Greymouth. Westport exports the coal of the Buller basin, where some seams are so high above the sea $(2,000$ feet $)$ that the coal has to be lowered by selfacting tramways to the railway which runs along the base of the mountain. Westport, though in no sense a good harbour, is protected from drift sand and west gales by Cape Foulwind. The level of the Greymouth district allows direct railway communication between the port and Cobden, the centre of the colleries.

Excellent coal also exists along the south-east coast, between Kaitangata and Dunedin, and between Palmerston and Oamaru; and the great advantage of this position arises, not from the convenience for shipping the coal, but from the fact that the main line of rail from Invercargill to Christehurch via Dunedin runs along the coast most of the way. Between Invercargill and Dunedin there is also coal inland, especially at Gore and Wyndham, in the Mataura valley. Oamaru, which,like the neighbouring "mutton" port of Timaru, has been made into a good artificial harbour, has a similar inland supply from Ngapara.

The gold is also found in both islands; but, again, the deposits in the South Island are distinctly the richer. The gold area in the North Island is the Coromandel Peninsula, the site of the first prospecting for gold in the colony; and most of the quartz mining hitherto has been confined to that district. The centres of the industry are Ohinemuri, Coromandel, and Thames. The towns of Coromandel and Thames can import machinery and coal or export the metal easily and cheaply; Thames has much the larger supply of water for working the diggings, while Coromandel is nearer the great timber district of Mercury Bay. 
The gold in the South Island is found in close proximity to the coal, i.e. in the north-west and the southeast. The north-west area is in Nelson and Westland, the south-east area is in Otago. In Nelson and Westland the mountains which shelter the plain of Nelson from the west winds are so high, so abrupt, and so near the sea, that precipitation is almost continuous and very heavy. Moreover, their slopes, both above and below the gold level, are covered with timber. There is, therefore, abundance of water for sluicing, and of timber for shafts, galleries, and tunnels. The chief centres in Nelson are in the basins of the Grey and Buller rivers, especially at Reefton and Lyell; but there are also deposits at Collingwood, where the much lower level is more favourable to the import of machinery and the export of the metal. In Westland the chief centres are near Kumara and Hokitika, both of which are on the sea; and the rocks between the two places were so rich in gold that, after a storm, nuggets were picked up on the beach. Of course, all along this part of the coast the mountains are so near to the sea that hydraulic mining cannot produce any devastation of rich agricultural land, as was the case in California; and the rivers are usually too short and too rapid for navigation, so that there need be no hesitation in choking them with débris.

In Otago the gold is found mainly in the valleys of the rivers that are thrown down from the Alpine lakes, especially in the valley of the Clutha ; and, as the Clutha is said to have a volume equal to that of the Nile, the supply of water is absolutely inexhaustible. The centre of the Clutha district is the famous coaching centre of Cromwell, a town of II,000 people, at a height of 4,000 feet. Towards the north-east of the province, where there is less abundance of water, e.g. on the slopes of Mount St. Bathans and Mount Ida, there is fortunately coal near the mines. 


\section{SOME MINOR BRITISH POSSESSIONS}

In the Indo-Paciflc areas the British possessions include the Straits Settlements, the Fiji Islands, and many isolated points such as Hong Kong, Singapore, North Borneo, Mauritius, etc. The Straits Settlements produce, tin, timber, spices, etc., exported mainly via Singapore; and the Fiji Islands export sugar-like Mauritiuscoco-nuts and copra-like the Seychelles-mainly from Suva and Levuka. The isolated possessions are chiefly imperial footholds, like Aden; but Borneo (with Labuan) produces excellent camphor, tobacco and coal. The German part of New Guinea is now administered by Australia, as that of Samoa is by New Zealand.

In the Atlantic all the important British possessions are north of the equator. Indeed, south of it the only possession of any importance now ${ }^{1}$ is the Falkland group. The islands are rugged and hilly, and the climate is exceedingly stormy; but coarse grass supports large flocks of sheep, whaling is important, and Port Stanley has great strategic value, as commanding the Horn route, and is often used as a repairing station by sailing vessels.

1 Before the cutting of the Suez Canal, Ascension and St. Helena-on the Cape route to the East-were of considerable value. 


\section{INDEX OF PLACE-NAMES WITH SOME PRODUCTS}

\section{A}

Aberdeen, 5, 4, 26, 45, 54

Abyssinia, 125

Accra, 124

Accrington, 55

Aconcagua, 12

Adelaide, 88

Aden, 88, 136

Africa, 19, 106-29

Agriculture, 3, 29, 39, 7.5, 88, I I I-I 3, 100-4, I I 7, I 20, I 22, 124

Agulhas C., 108

Ahmadabad, I02

Akasa, I 24

Akola, 102

Akyab, 105

Albany, 82, 106

Alberta, 65, 75

Alexandria, 128

Algoa B., 108

Algoma, 15, 78

Aliwal North, 1 io

Allahabad, ror

Alloa, 46, 59

Amazon, I 6

Amraoti, 102

Amritsar, roo

Andes, 15, 19, 20

Antwerp, 43

Apatite, 78

Appalachian MIts., I 3

Arafura, 85

Arakan, 15

Ararat, 89,92

Aravalli, I

Ardrossan, 58

Argentina, 49
Asaba, 124

Asiut, 128

Assam, 97, 104, 107

Aswan, 128

Athabasca, I 5

Atlantic, 29, 4I, 46, 61, 62, 64, 71,136

Attock, 97

Auckland, I 30, I 33

Australia, 2, 10, 19, 27, 31, 33, 38

relief, I 2, r $8,84-6$

pasture, $86-8$

wool, 5 I

artesian, I 6

fish, 23

railways, 23

agriculture, $88-90$

minerals, $90-4$

labour, 7,89

Azores, 36

B

Bahamas, 36

Ballarat, 89,92

Baltic, 32, 46

Banff, 77

Barbados, 8r

Barberton, I 20

Baro, 124

Baroda, IO2

Bassein, I05

- Basutoland, I I 4

Bathurst, I24

Bechuanaland P., II4, I IS

Behar, 103, ro4

Beira, 123

Belfast, $47,5^{8}, 60$ 
Belsize, $8 \mathbf{I}$

Benares, 99

Bendigo, 92

Bengal, I03, I04

Bengal Bay, 94, 97, 98, ro 1, I05

Benguela, I06

Benué, I 24

Berar, I02

Berber, I 23, I 28

Bermuda, 36, 80, 8r

Berwick, 47

Bethlehem, I 2 I

Bethulie, I2 I

Birmingham, 27, 50, 57

Blackburn, 55

Black Country, 57

Black Forest, I 7

Black Sea, 3 I

Blantyre, I 25

Blenheim, I 30

Bloemfontein, II I, I I9, I 2 I

Bloemkof, I 20

Bogota, 20

Bolan, 96

Bolivia, 2 I

Bolton, 55

Bombay, 30, 31, 34, 74, 99, I0I, I 02

Bonny, I 24

Bordeaux, 30,76

Borneo, I 36

Bourke, 86

Bradford, $5^{6}$

Brahmaputra, 96, 103

Brazil, 6

Breede, I I 3

Brindisi, 24

Brisbane, 83, 89, 90, 9 I

Bristol, 44, 57

British Central America, 8o, 8I

British Columbia, 74, 75, 78

British Honduras, 8o

Broken Hill, N.S.W., 93, I 23

Bucharest, 24

Bulawayo, I 2 I, 122

I3ulgaria, 32

Bulli, 9 I

Bundaberg, 90

Burdekin, 92

Burma, 105

Burnley, 55

liurton, 49
Bury, 55

C

Cadiz, 24

Cairns, 84, 89

Cairo, I 18 , I 28

Calais, 24

Calcutta, 94, 95, IOI, 103

Caledon, I I 4, I 2 I

Calgary, 75, 77

Calicut, 99

Campbelltown, I 30, I 3 I

Canada, 29, 32, 33, 34, 45, 52, 6o surroundings, $60-4$

surface, 64,65

wheat, 9, 5 I, 65-7 I

railways, $22,33,63,67,75$

fisheries, 64,80

timber, $7 \mathrm{I}-4$

coal and iron, $76-9$

pasture, 74

fruit, 75

Canterbury (N.Z.), I 32

Cape of Good Hope, 28, 30, 36, Io8

Cape Town, 30, 8r, 107, I I 2 , I 8 , I 2 I, I 23

Cardiff, $44,55,58$

Caribou, 78

Castlemaine, 89

Cauvery, 98, I03

Ceylon, ro5

Charleville, 86

Charlotte Town, 62

Charters Towers, 84, 92

Chaudière Falls, 73

Cheddar, ${ }_{4}^{8}$

Cheese, 75

Cherra-Pungi, 97

Cheviot Hills, 47

Chhattisgarh, IOI

Chicago, 24

Chignecto, 32

Chillagoa, 93

Chindé, I 25

Chinook, 68

Chiromo, I 25

Cleveland, 60

Christchurch, I 30, I 33, I 34

Chittagong, 103

Claremont, 9 I 
Climate, economic bearings, 5-1 2 Cloncurry, 93

Clutha, 17, 132, 133, 135

Clyde, 40, 43

Coal, 5, 17, 30, 36, 42-50, 54-5, $57-60,63,76,83,90$

Coatbridge, 59

Cobar, 9r, 93

Coimbatore, 99

Collingwood, I 35

Colombia, 20

Colombo, 106

Comox, 77

Congo, 16

Constantia, I 12

Constantinople, 24

Cook Strait, I 29

Cooktown, 84

Coolgardie, 92

Coorg, r 04

Copper, 48,93 , II 3 , I I 5

Cordilleras, 17

Corinth, 3I

Cork, 47

Cornwall, 48, 54, 57

Coromandel, 134

Cotton, 58, ror, 123, I 51

Cotswold, 57

Coventry, 56

Crewe, 24

Cromwell, 135

Cumberland, 5

Cuxhaven, 30

Cyphergat, II 3

\section{D}

Damietta, 128

Damodar, 96

Danube, 18

Dar-es-Salaam, 127

Darjeeling, I03, $\mathrm{IO}_{4}$

Darling R., 85, 86

Deccan, 14,98

De Kaap, 120

Delhi, 98, 99

Delphi, 3 I

Demerara, $8 \mathrm{r}$

Deseronto, 73

Detroit, 64

Devon, 48,57

Dibrugarh, IO 4

Doncaster, 56
Dorset, 48

Dover, 44

Draken-berge, 107, 109, I 14-16, I 19

Duluth, 62

Dumbarton, 59

Dundee, 45 ; (S.A.), II 8

Dunedin, I 30,134

Dunfermline, 59

Dunmore, 78

Durban, I I 5, II 7

Durham, 55

\section{E}

EAST LoNDON, ro8, yYo, I 2 I

Ecuador, 20

Edinburgh, 50

Edmonton, 78

Egypt, 6, 9, 17, 127-9

Elandsfontein (see Germiston), I 2 I

Elbe, Ix, 36

Elbruz, I 2

El Obeid, 127

England, 42-5

Entebbe, I 26

Ermelo, 120

Esquimalt, 63, 77

Euphrates, 4

Europe Coast, 40

Everest, 12

Exeter, 47

F.

FALKIRK, 59

Falmouth, 44

Fashoda, 127

Fauresmith, I 2 I

Fayum, 128

Festiniog, 6o

Fiji, 136

Fingal, 94

Fishguard, 44

Fishing, 23, 35, 53, 64, 80

Floods, ro

Folkestone, 44

Fort Churchill, 6r

Fort Norman, 77

Fort Salisbury, 122

Fort Victoria, 122

Fort William, 62 
Fort York, 6r, 79

Forth, 40, 45

Frankston, 23

Fraser, 78

Fraserburgh, 54

Fredericton, 72, 73

Freetown, 124

Fremantle, 83, 92

Fruit, Canada, 75

Fundy, Bay of, I I, 32, 63, 74

GALLE, 106

Galway, 46

Gambia Colony, I 24

Gamtoos, I09

Ganges, 4, 5, 96, 97, 101, 103

Geelong, 87

Genoa, 24

Georgetown, 8I

Geraldton, 90

Germany, 10, 36, 42

Germiston, I20, I $2 \mathrm{I}$

Ghazipur, 103

Gibraltar, 36

Glasgow, 18, 38, 45, 50, 56, 59, 87,90

Gloucester, 48

Goalpara, 103

Godaveri, 98

Gold, I 8, 84, I04, I I9

Gore, I 34

Graaf Reinet, I IO, I I I

Grahamstown, I09, II I, I I 2

Grangemouth, 59

Great Barrier Reef, 83

Great Biitain, I8, 19, 24, 31, $48-60$

position, 38,78

transport, $18,25,37,53,54,56$ coal, 36

fishing, 35

Great Fish R., Iog

Great Grimsby, 25, 43, 54

Great Lakes, 38, 64, 65, 69, 7 I

Great Slave Lake, 65

Greece, 4

Greenland, 19, 38

Grcenock, 59
Grenada, 8r

Greymouth, 134

Greyton, I I 7

Griqualand, II 3

Guardat, 20

Guaritz, 109

Guayaquil, 2I, 3 I

Gujarat, IO2

Gulf of Lyons, I7

Gulf Stream, 8, 62, 63, 80

Gwelo, 123

Gympie, 93

$\mathrm{H}$

Halifax, 56; (Canada), 62, 73 , 74,76

Hamburg, 24, 30

Hamilton, 76

Harrismith, I 8

Hart, I I 3, I I $4_{4}$

Hartlepool, 42, 55

Hartley Hill, 122

Harwich, 43, 54

Hastings, 23

Hawkesbury R., 9 I

Heidelberg, I 20, I 2 I

Heilbron, I 2 I

Helena, 78

Himalaya, 96

Holland, 5, 6, 20

Holyhead, 44

Hond, 20

Hokitika, 135

Hoshangabad, roo

Huddersfield, 56

Hudson Bay, 61, 67, 69, 7I, 79

Hughenden, 86

Hull, 43, 56

Humber, 40, 42, 56

Hunter, 9 I

Huron L., 78,79

ICELAND, 53

Illawarra, 84, 9 I

Illorin, 124

Incas, 21 
India, 9, I 4, 20, 31, 33, 34, 38 surroundings, $94^{-6}$ surface, $96 \rightarrow 9$ pasture, 99, 100 agriculture, 100-4 timber, 100 minerals, 96, 104, 105 routes, 99

Indus, 96

Industries, 50

Invercargill, 134

Inverell, 93

Ipswich, 90

Irawadi, I05

Ireland, 46, 54, 59

Iron, $42,46,48,50,76,91$

Isipingo, II 7

Ismalia, 128

Italy, 3I

\section{J}

JAGERSFONTEIN, I2I

Jamaica, 36, 8I

Japan, 37

Jarrow, 42, 55

Johannesburg, I II, II9, I20

Jute, 34, 103

\section{$\mathrm{K}$}

Kaitangata, I 34

Kalahari, II 8

Kalgoorlie, 92

Kangra, 103, 104

Kano, 124

Kanya, i 8

Karachi, 94, 95

Karoo, I09, I I0

Kashmir, 100

Kenya, I 25

Khaibar, 96

Khamgaon, 102

Khandesh, I02

Khandwa, 99

Khartum, I 23, 127

Kiel, 32

Kigoma, 127

Kildonan, 69

Kilimanjaro, 12, 126
Kilkenny, 59

Kilmarnock, 58

Kingston, $8 \mathrm{I}$

Kimberley, II 3

Kioga L., I 26

Kirkcaldy, 59

Kistna, 98

Kivu L., 127

Klerksdorp, I 20

Klondyke, 78

Kobe, 3 I

Komati Poort, I 21

Kotan, ${ } 04$

Kroonstad, I21, 124

Krugersdorp, I 20

Kumasi, I 24

Kumura, I 35

Kuruman, II 4

L

LABRADOR, 9, 62, 64

Labour, 7, 5I, 8o

Lado, 127

Ladybrand, I 2 I

Lagos, 124

Lahore, 94, 100

Lakes, 18

Lancashire, 35, 44, 55

Lange-berge, I I 2

Latitude, 8

Launceston, 93

Laurenço Marques, 120

Leeds, $49,50,56$

Leicestershire, $4^{8}$

Leith, 45

Lethbridge, 78

Levuka, 136

Libau, I4

Light, 8

Limerick, 46, 60

Limpopo, 107, II9

Lisbon, 30

Lithgow, 9 I

Liverpool, I8, 24, 3r, 44, 49, $50,55,56,6 \mathrm{I}, 64$

Loangwa, 123

London, $5,9,18,25,30,39,43$, $49,50,53,54,56,64,87,90$

Londonderry, 60

Longford, 94 
Louisberg, 76

Lydenberg, I 20

Lyell, 135

M

MACKAy, 89, 92

Mackenzie, 77,79

Madeira, 30,36

Madras, 94, 96, I01, I03

Mafeking, I $13, I_{14}, I_{1} 8$

Magdalene, 20

Mahanadi, 100

Makum, ro4

Malta, 36

Manchester, 31, 49, 55

Mandalay, I05

Manila, 3I

Manitoba, 65

Manufactures, 3, 54

Manukau, 130

Marlborough, 132

Maryborough, 57, 90, 91, 92

Maseru, I I 5

Mashonaland, 107, I19, 122

Matabeleland, 107, 119

Mataura, 134

Matoppo, 123

Maulmein, 105

Mauritius, 106

Melbourne, 82, 92

Mendip, 48

Mercer, 133

Mersey, 40, 44

Merthyr Tydvil, 58

Middlesbrough, 42, 55

Middlewich, 60

Milford Haven, 44

Milk, 52

Minas Basin, 76

Mirzapur, Ior

Mississippi, 10, 16, 71

Missouri, 10

Molopo, II 4

Molteno, II 3

Mombasa, 125

Montreal, 6r, 62, 73

Montscrat, $8 \mathrm{I}$

Moonta, 93

Morea, $3 \mathbf{I}$

Mloscow, 15

Mosgicl, I 30
Mossel Bay, 1 I 2

Mount Bobby, 9 I

Mount Ida, 135

Mount Kosciusko, 85

Mount Lyall, 93

Mount MI'Kinley, I 2

Mount Margaret, 92

Mount Morgan, 92

Mount Rochfort, 134

Mount St. Bathans, I 35

Mozambique, 107-9, I 6

Multan, 100

Murchison, 92

Murray, 85,89

Murrumidgee, 85

Mysore, 100, 104

$\mathrm{N}$

NagambIE, 89

Nagpur, 99. 102

Nairobi, 126

Namaqualand, II 3

Nanaimo, 97

Nantes, 30

Nantwich, 60

Narbada, 100

Narsinghpur, I 00

Natal, $7,32,115-18$

Negapatam, 99

Nelson 130, 132, 135

" River, 61

Nepean, 9I

New Brunswick, I 4, 72, 73

Newcastle, I 8, 42, 54, 55

(Aust.), 84, 91

(Africa), I I 8,121

(N.Z.), 133

Newfoundland, 41, 79

New Glasgow, 77

New Guinea, 136

Newhaven, 44

New Orleans, 30

Newport, $5^{8}$

New South Wales, 86

agriculture, 88-90

wool, 86

minerals, 90-4

railways, 23

New Westminster, 63

New York, 5, 24, 30, 76, 77 
New Zealand, $7,7,13,15,17,20$, $22,23,29,31,36$ position, 129-31 surface, I3I pasture and agriculture, $13 \mathrm{I}-3$ minerals, 133-5

Ngapara, 134

Niagara, $8,14,17,79$

Nieuweld, 109

Nigeria, 124

Nile, 16, 17, 125, 127

Nilghiri, 99

North Sea, II, 32

North Shields, 55

Norval's Pont, I 2 I

Norway, 8

Nova Scotia, $29,33,35,72,74$, 75,76

Nyasa L., 127

Nyasaland, I 25

Nylstroom, I 20

OAmaru, 134

Odessa, 24

Ohin, 10, 16

Oldham, 55

Olympia, 31

Onehunga, 130, 133

Ontario, 53, 73, 74, 78

Ookiep, I 13

Orange Free State, II9

Orange R., 109, I13, I19, I 21

Otago, 132, 135

Ottawa, 32, 73

Oudtshoorn, II 2

\section{P}

PAARL, 112

Paisley, 59

Palmerston, 134

Panama, 30, 36

Paris, 24

Parnassus, 31

Pauillac, 30

Pembra, 125, 127

Peninsula, 15, $48,55,56$

Pentland, 59

Perim, 36
Perth, 45; (W.A.), 83

Petrograd, 24

Pietermaritzburg, I 7

Pietersburg, I 20, I 21

Plymouth, 54

Port Alfred, i I I

Port Augusta, 82, 88, 92

Port Chalmers, i 30

Port Darwin, 83

Port Elizabeth, I 10

Port Florence, 126

Port Herald, I 25

Port Lyttleton, 130

Port Natal, I 5

Port Nelson, 6 I

Port Nicholson, 130

Port Phillip, 82

Port Pirie, 82, 88, 93

Port Royal, 8I

Portsmouth, 43

Port Stanley, 136

Potchefstroom, i 20

Preston, 55

Pretoria, III, I19, I20, I2 I

Prince Albert, I 12

Prince Edward Island, 4 r

Prince Rupert, 63

Puma R., 102

Pungwe Valley, I 22

\section{Q}

QUebec, I4 62,73

Queensland, $7,23,77,84-9$ I

Queenstown, 45

Quinte Bay, 74

Quito, 2 I

\section{$\mathrm{R}$}

RAILWAYS, 22-7, 33, 37, 50, 67, $77,78,92,99,103,116,126$, 127

Rangiriri, I33

Rangoon, 105

Rangpur, IO 3

Ravenswood, 84,92

Reading, 49

Red R., 67, 79

Red Sea, I $2 S$

Reefton, I 35

Restigouche R., 72 


\section{A COMMERCIAL GEOGRAPIIY}

Rhodesia, 122, I 23

Rhine, I7

Rhone, I6, I 7

Richmond (S.A.), I 17

Riga, 24

Rochdale, 55

Rockhampton, $83,91,92$

Rocky Mits., I 5, Is, 66

Rokella, I 24

Roma, 89

Rosetta, 128

Rotterdam, 24, 43

Russell, I30, I3 I

Russia, I 5, 19, 56

Rutherglen, 89

\section{S}

SABAKI, 125

Sagar, roo

St. Helena, Io

St. Helens, 56

St. John, 63, 73

, ," River, 72

St. Johns, 79

St. Lawrence, 16, 17, 62, 73

St. Nazaire, 30

St. Thomas, 36

Saldanha, 107

Salisbury, I 22,123

Salonica, 24

Samoa, 136

Sandhurst (V.), 87

Sarbarmati, 102

Saskatchewan, 18, 65, 77

Satpura, 99

Scotland, 4, 1 5, 45, 46 fish, 53,54

coal, 58

Sebastopol, 24

Sekondi, I 24

Selukwe, I 23

Sennar, 127

Serviceton, 92

Severn, 40, 57

Seychelles, 136

Shaffhausen, I 7

Shanghai, 3 I

Shannon, 46

Shark Bay, 83
Sheffield, 56

Shepparton, 89

Shipping, 38, 55

Shipbuilding, 55, 59

Shoshong, i 8

Sibsagar, $\mathrm{IO}_{4}$

Sierre Leone, I 24

Silchar, 104

Silverton, 93

Simla, IO3

Sind, 97

Singapore, I 36

Singareni, IO4

Smithfield, I 2 I

Sneeuw-berge, Io9

Soil, 2, 14, 69, 102

Sokoto, I 24

Sokotra, 123

Solway, 40

Somaliland, I 23

Somerset, $4^{8}$

Southampton, 12, 43, 44

South Africa

position, 106

surface, 108

climate, Io9

pasture and agriculture, I IO-I

minerals, I I 3

South Australia, 23, 87-9

Southern Alps, I 31 , I 32

South Shields, 55

Spencer Gulf, 82, 83

Springfontein, 121

Standerton, 120 , I 21

Stawell, 89, 92

Stellenbosch, I 12

Stilton, 48

Stockport, 55

Stockton, 42

Stoke, 56

Stonehaven, 47

Storm-berge, 109

Stornoway, $5 f$

Strangford Lough, $4^{6}$

Strathmore, 49

Stroud, 57

Suakin, I 23, 128

Sudan, 123

Sudbury, 15, 78

Suez, 30, 35, 36, 64, 95, 123, 128, I 29

Sulaiman, 96 
Sunderland, 42, 55

Superior L., 10, 64

Surat, 30, 102

Suva, 136

Swakozmund, I 15

Swansea, 44

Swaziland, I 2 I

Swindon, 24

Sydney, 83, 84, 91

\section{$\mathrm{T}$}

TABLE BAY, 108

Tadousac, 73

Tanga, I 27

Tanganika, ı07, 125-7

Tapti, 99, 102

Ta ranaki, I 33

Tasmania, 7,93

Taungs, I I 4

Tay, 45. 49

Tea, 103, 105

Tees, 42, 55

Tenasserim, 105

Textile, 55

Thames, I1, 16, 36, 40, 42, 43 , 49 ; (N.Z.), I 34

Thar, 97

Tides, 11,40

Timaru, 134

Tingha, 93

Tinnevelli, 102

Tobacco, 103, $117,123,127$

Togoland, 124

Tonnage, 37,64

Toowoomba, 86

Townsend Mt., 85

Townsville, $83,84,89$

Transport, 18

railway (see Railways), 22-7

water, $27,4^{\circ}$

canals, 27-3I

Transvaal, I I , I I9-2I

Trent, 49

Trichinopoli, 99, I02

Trincomali, 106

Trinidad, 8 I

Truro C., 77

Tsaritsin, 24

Tugela, I I 7

Tula, 15
Tyne, 40, 42, 55

Tynemouth, 55

\section{$\mathrm{U}$}

UGANDA, 125, I 26

Ujiji, 127

Uitenhage, I I I

Umtali, I 23

United States of America, I3, $25,37,4^{0}, 46,65,67$

Usambara, 126

\section{V}

VAAL, I I 3, I I 4

Valparaiso, I 3 I

Vancouver, 63

Vegetation, 9

Veld, I 19, 120, I 2 I

Vereeniging, 120

Verulam, I I 7

Victoria (Can.), 63

(Aust.), 82, 83, 87, 88, 89, 92

Victoria Falls, 123

Victoria Nyanza, I 25, I 26

Vindbya, 99

Vine, 30, 89, I I 2

Volta, I 24

Vosges, I 7

Vryburg, I 3 3, if t

Vrybeid, I I 8

W

WAdI HALFA, I 28

Waikato, I 33

Waitemata, I 30

Wakefield, 56

Wales, 53. 60

Walfish B., I I 5

Wallaroo, 93

Wallsend, 134

Walsall, 57, 60

Wankie, 123

War, 32

Wardha, 102, IO4

Warrington, II 4

Warwickshire, $4^{8}$ 
Water power, 7, 8, 10

Wear, 55

Wellington, 130,132

Wentworth, 83

Western Ghats, 95, 98, 100

Westland, 132, 135

Westmoreland, 25

Westport, I 34

Whangarei, I 33

Wheat, 7, 9, 65-7 I, 100

Whitehaven, 5I, 57

Wick, 25, 54

Widnes, 56

Windsor (N.S.), 79

Winnipeg, 24, 61, 76

Winton, 86

Winter-berge, rog

Witwatersrand, II 9

Wollongong, 91

Wolverhampton, 27, 57

Wool, 49, 56, 82, 86-8, I I0-11,
Workington, 57

Wyalong, 9I

Wynberg, I 12

Wyndham (N.Z.), 134

Wyoming, 25

Y

YANGTSE, 14

Yarmouth, 42, 53

Yorkshire, $4^{8}$

Yukon, 73

\section{Z}

ZAMBESI, IO6, I 22

Zanzibar, 107, 125, 127

Zcila, I 23

Zomba, 125

Zungeru, 124

Zwate Berge, II 2 


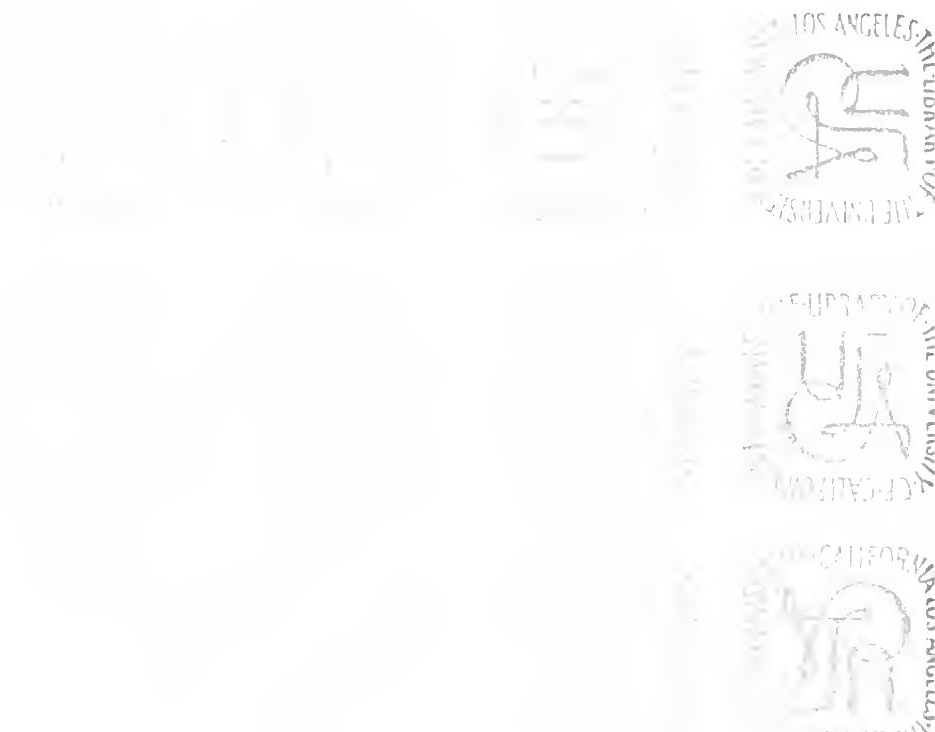
$\because$ in 2 पी

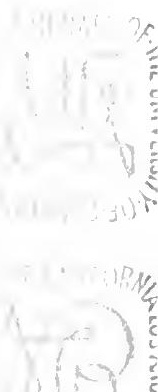




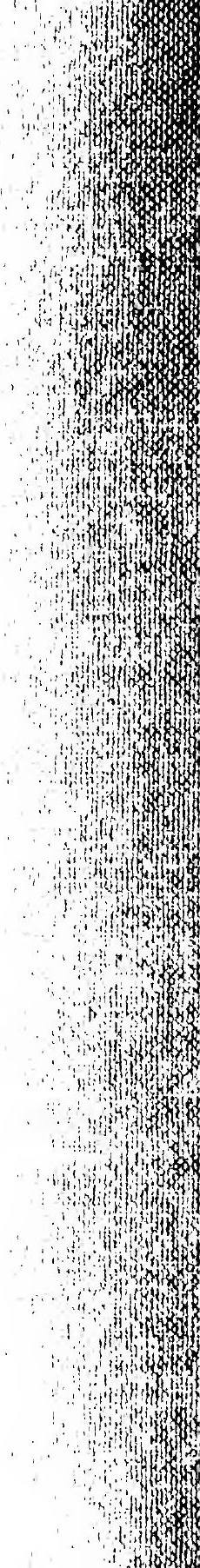

